\title{
A Screening Approach for the Discovery of Mechanochromic Gold(I) Isocyanide Complexes with Crystal-to-Crystal Phase Transitions
}

Tomohiro Seki, * Yuki Takamatsu, and Hajime Ito*

${ }^{1}$ Division of Applied Chemistry \& Frontier Chemistry Center (FCC), Faculty of Engineering,
Hokkaido University, Sapporo, Hokkaido 060-8628, Japan

seki@eng.hokudai.ac.jp

hajito@eng.hokudai.ac.jp

- Contents

$\begin{array}{ll}\text { 1. General } & \text { S2 }\end{array}$

2. Excitation and Emission Spectra of Unground and Ground $\mathbf{R}^{\mathbf{1}}-\mathbf{R}^{\mathbf{2}}$ Phases. $\quad S 3$

3. Preparation of the Single Crystals of $\mathbf{R}^{1}-\mathbf{R}^{\mathbf{2}} \quad \mathrm{S13}$

4. Excitation and Emission Spectra of As-Prepared Powders and Single Crystals of $R^{1}-R^{2} \quad S 17$

5. Comparisons of Simulated Powder and PXRD Patterns of $\mathbf{R}^{1}-\mathbf{R}^{2} \quad$ S24

6. Photophysical Properties of $\mathrm{CF}_{3}-\mathrm{CN} \quad$ S33

7. DSC Analysis of $\mathrm{CF}_{3}-\mathrm{CN}_{\mathrm{G}}$ and $\mathrm{CF}_{3}-\mathrm{CN}_{\mathrm{Y}} \quad \mathrm{S35}$

8. Comparison of Powder Patterns of $\mathrm{CF}_{3}-\mathrm{CN}_{Y}$ and $\mathrm{CF}_{3}-\mathrm{CN}_{\text {ground }} \quad \mathrm{S36}$

9. Comparison of Excitation Spectra and Calculated Spectra of $\mathrm{CF}_{3}-\mathrm{CN} \quad \mathrm{S37}$

10. Intermolecular Interactions in the Single Crystals $\mathbf{R}^{1}-\mathbf{R}^{2} \quad \mathbf{S 3 8}$

$\begin{array}{ll}\text { 11. Synthesis } & \text { S40 }\end{array}$

$\begin{array}{ll}\text { 12. References } & \text { S60 }\end{array}$ 


\section{General}

All commercially available reagents and solvents are of reagent grade and were used without further purification unless otherwise noted. Solvents for the synthesis were purchased from commercial suppliers, degassed by three freeze-pump-thaw cycles and further dried over molecular sieves (4 $\AA$ ). NMR spectra were recorded on a JEOL JNM-ECX400P or JNM-ECS400 spectrometer $\left({ }^{1} \mathrm{H}: 400\right.$ $\mathrm{MHz} ;{ }^{13} \mathrm{C}$ : $99.5 \mathrm{MHz}$ ) using tetramethylsilane and $\mathrm{CDCl}_{3}$ as internal standards, respectively. Emission spectra were recorded on a Hitachi F-7000 spectrometer. Fluorescence microscopic spectra were recorded on a Photonic Hamamatsu PMA-12 Multichannel Analyzer. The emission quantum yields of the samples were recorded on a Hamamatsu Quantaurus-QY spectrometer with an integrating sphere. Emission lifetime measurements were recorded on a Hamamatsu Quantaurus-Tau spectrometer. Photographs were obtained using Olympus BX51 or SZX7 microscopes with Olympus DP72, Nikon D5100 or RICOH CX1 digital cameras. DSC analyses were performed on Seiko EXSTAR (DSC7200) under a nitrogen atmosphere.

$X$-ray diffraction analyses: Single crystal X-ray structural analyses were carried out on a Rigaku R-AXIS RAPID diffractometer using graphite monochromated Mo- $\mathrm{K}_{\alpha}$ radiation. The structure was solved by direct methods and expanded using Fourier techniques. Non-hydrogen atoms were refined anisotropically. Hydrogen atoms were refined using the riding model. All calculations were performed using the CrystalStructure crystallographic software package except for refinement, which was performed using SHELXL-97. ${ }^{\text {S1 }}$ Simulated powder patterns were generated with Mercury 3.0 from the structures determined by single crystal diffraction analyses. ${ }^{\mathrm{S} 2}$

TD-DFT calculations: All calculations were performed using the Gaussian 09W (revision C.01) and Gaussian 09 program package. ${ }^{\mathrm{S} 3}$ In the calculations, B3LYP functionals and the SDD basis set were used. ${ }^{\text {S4 }}$ The geometry of the tetramer structures of $\mathbf{C F}_{\mathbf{3}} \mathbf{-} \mathbf{C N}$ were calculated using coordinates of heavy atoms taken from the corresponding X-ray structures. The positions of these heavy atoms were fixed and only the positions of $\mathrm{H}$ atoms were optimized using the Spartan '10 MMFF force-field calculation. ${ }^{\mathrm{S} 5}$ Molecular orbitals were drawn using the Avogadro 1.1.0 program. ${ }^{\mathrm{S} 6}$ 


\section{Excitation and Emission Spectra of Unground and Ground $\mathbf{R}^{\mathbf{1}}-\mathbf{R}^{\mathbf{2}}$ Phases.}

Figures S1-S6 show excitation (dotted lines) and emission spectra (solid lines) of $\mathbf{R}^{\mathbf{1}}-\mathbf{R}^{\mathbf{2}}$ obtained before (denoted as "i") and after (denoted as "ii") mechanical stimulation.

- $\quad$ Figure S1 a)-f): Spectra of $\mathbf{O M e}-\mathbf{R}^{2}$.

- $\quad$ Figure $\mathrm{S} 2 \mathrm{a})-\mathrm{f})$ : Spectra of $\mathbf{M e - \mathbf { R } ^ { 2 }}$.

- $\quad$ Figure S3 a)-f): Spectra of $\mathbf{H}-\mathbf{R}^{2}$.

- $\quad$ Figure S4 a)-g): Spectra of Cl-R $\mathbf{R}^{2}$.

- $\quad$ Figure S5 a)-f): Spectra of $\mathbf{C F}_{\mathbf{3}}-\mathbf{R}^{\mathbf{2}}$.

- $\quad$ Figure S6 a)-f): Spectra of $\mathbf{C N}-\mathbf{R}^{2}$.

Colors of the lines are corresponding to the emission colors of each sample. Black lines denote the spectra of ground phases whose emission colors were identical to those of the corresponding unground phases. The monitored emission wavelength and excitation wavelength are all summarized in Table S1. 
a)

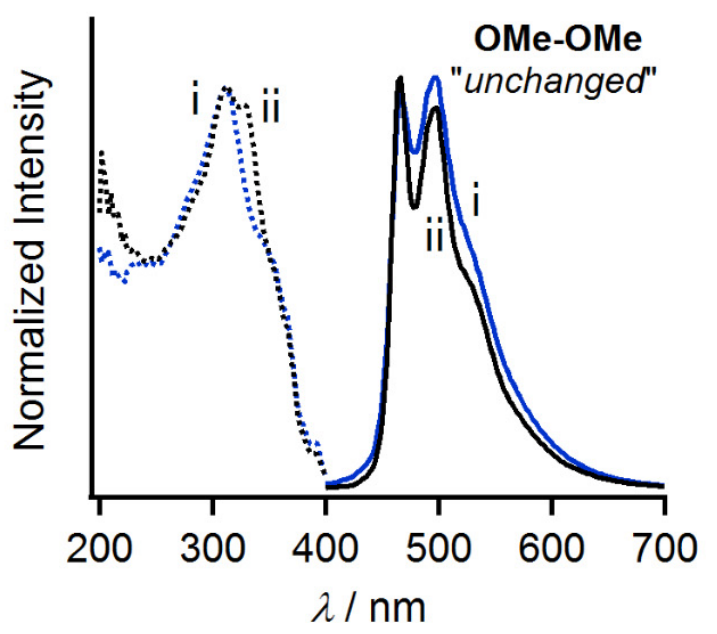

c)

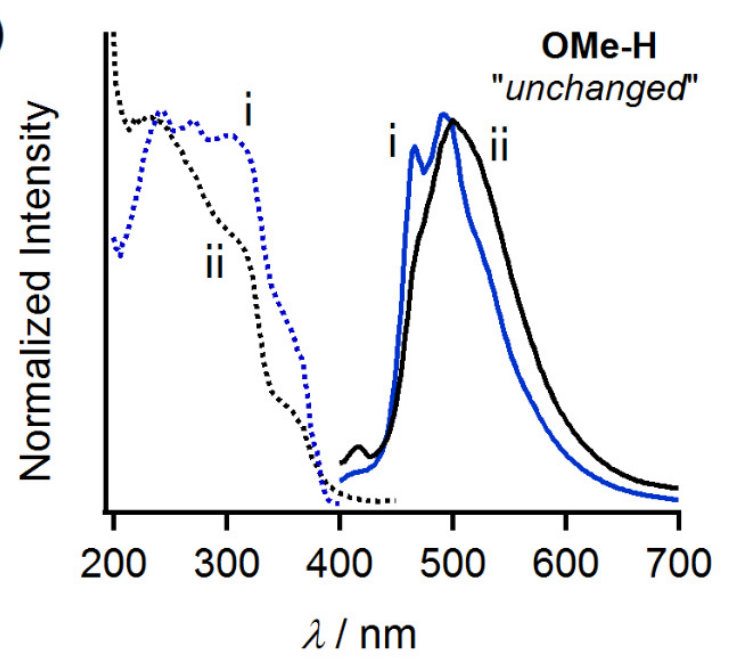

e)

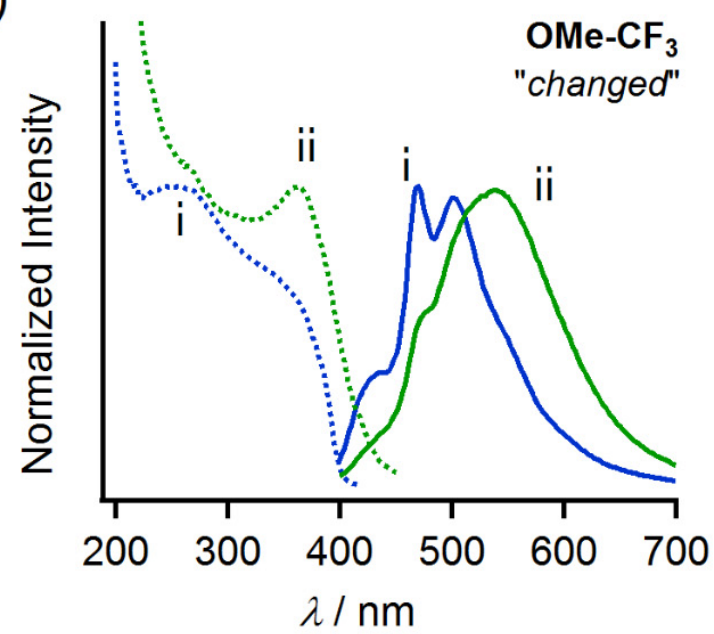

b)

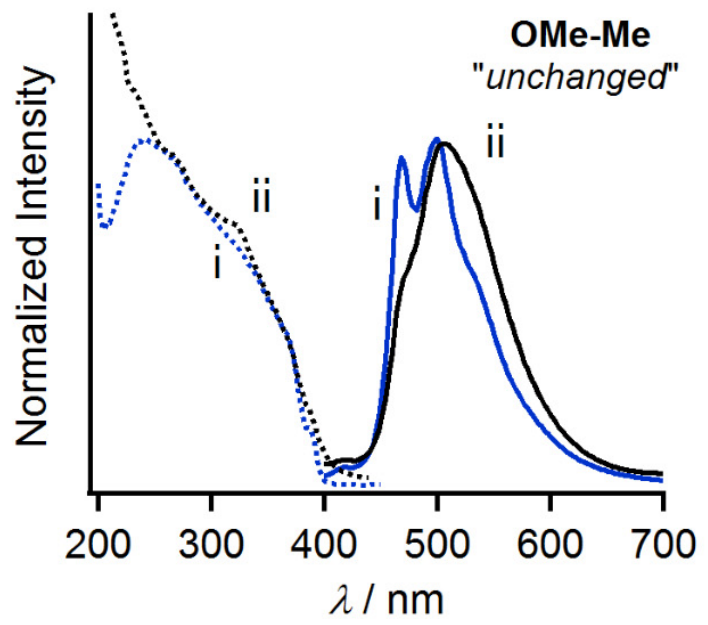

d)

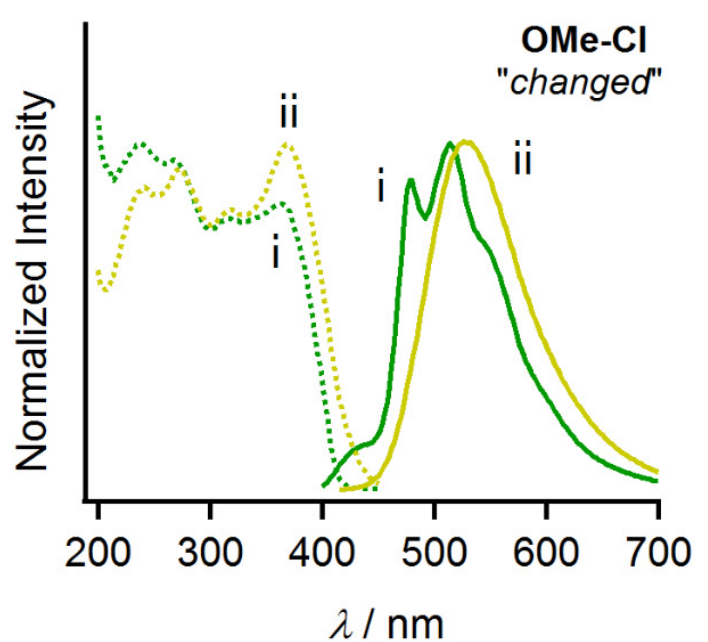

f)

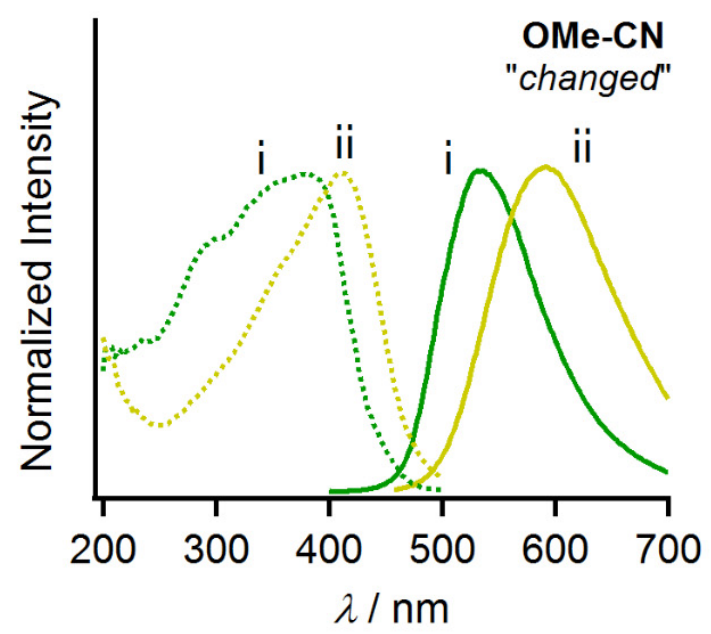

Figure S1. Excitation (dotted lines) and emission spectra (solid lines) of as-prepared (denoted as "i") and ground phases (denoted as "ii") of a) OMe-OMe, b) OMe-Me, c) OMe-H, d) OMe-Cl, e) $\mathbf{O M e}-\mathbf{C F}_{3}$, and f) $\mathbf{O M e - C N}$. The measurement conditions are summarized in Table S1. 
a)

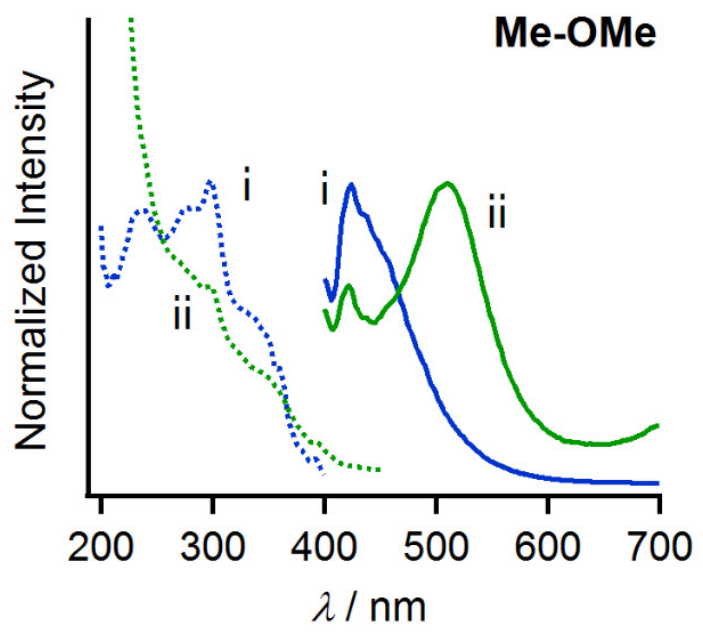

c)

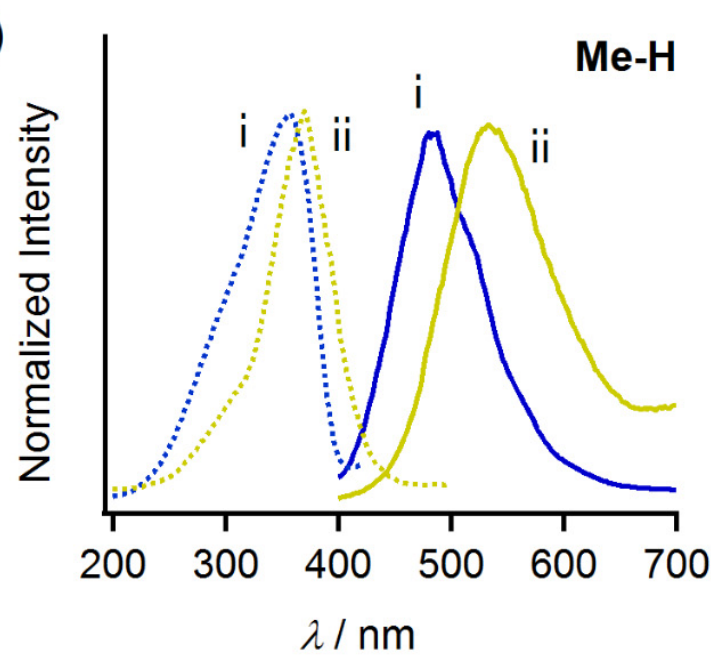

e)

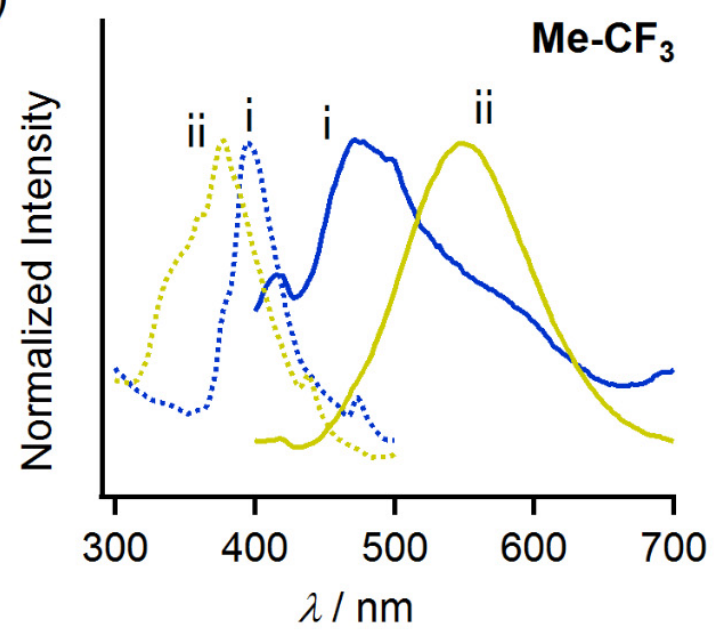

b)

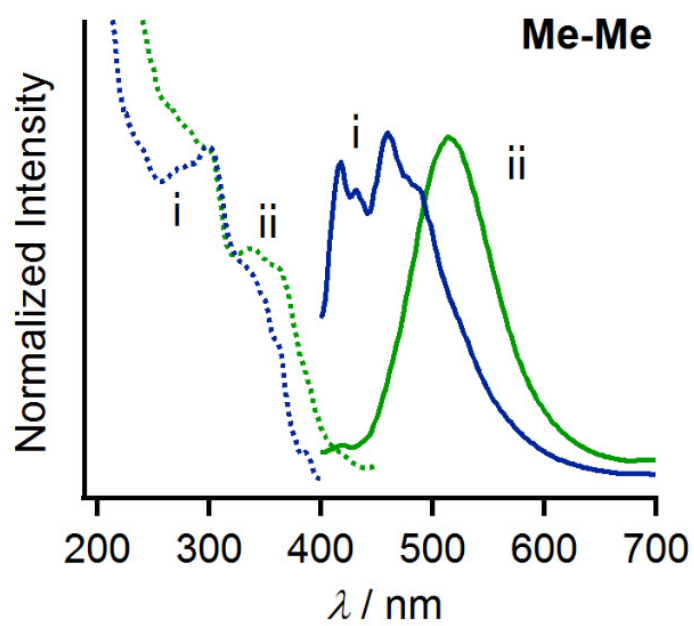

d)

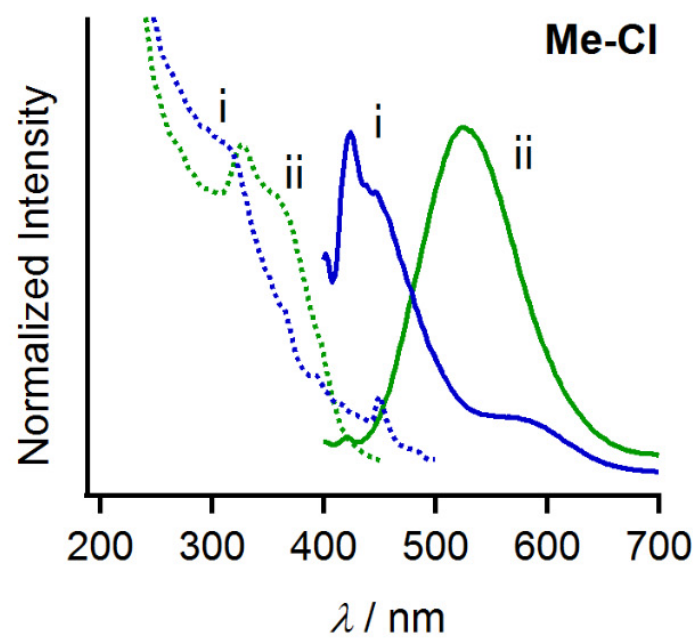

f)

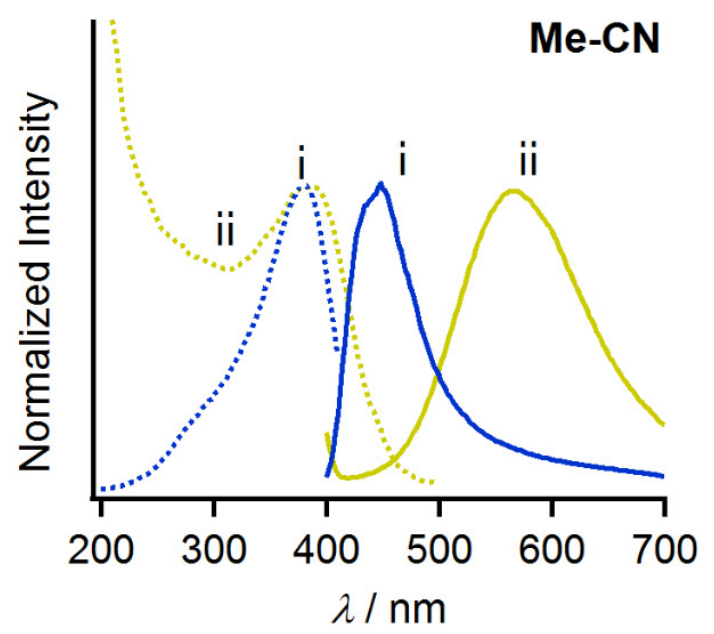

Figure S2. Excitation (dotted lines) and emission spectra (solid lines) of as-prepared (denoted as "i")

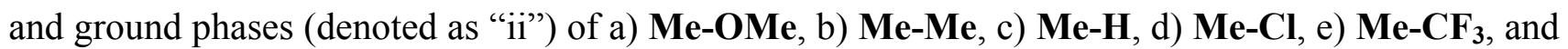
f) Me-CN. The measurement conditions are summarized in Table S1. 
a)

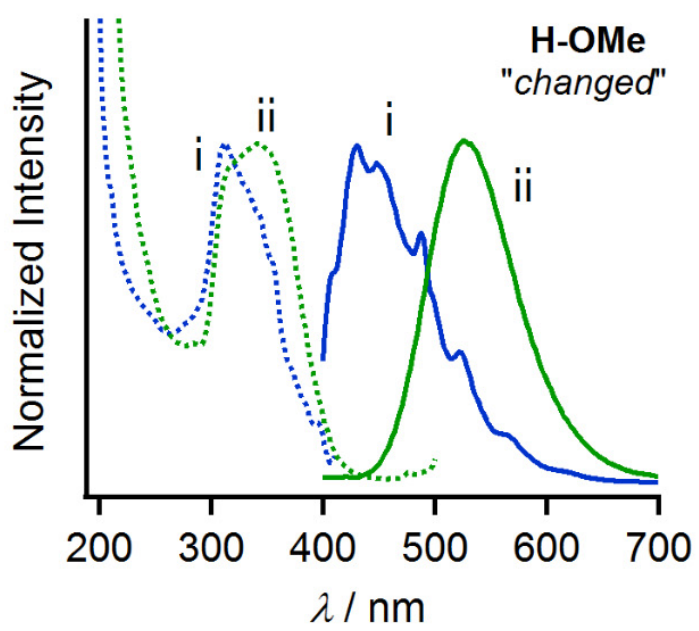

c)

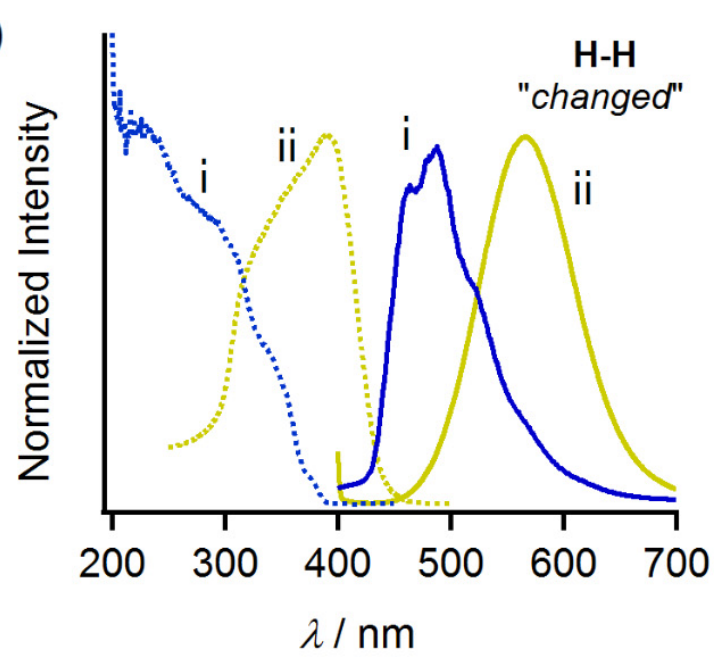

e)

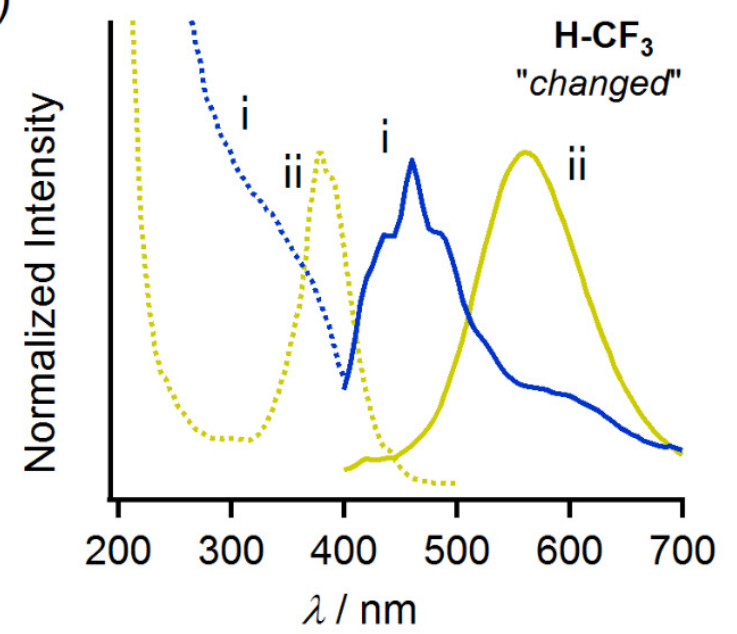

b)

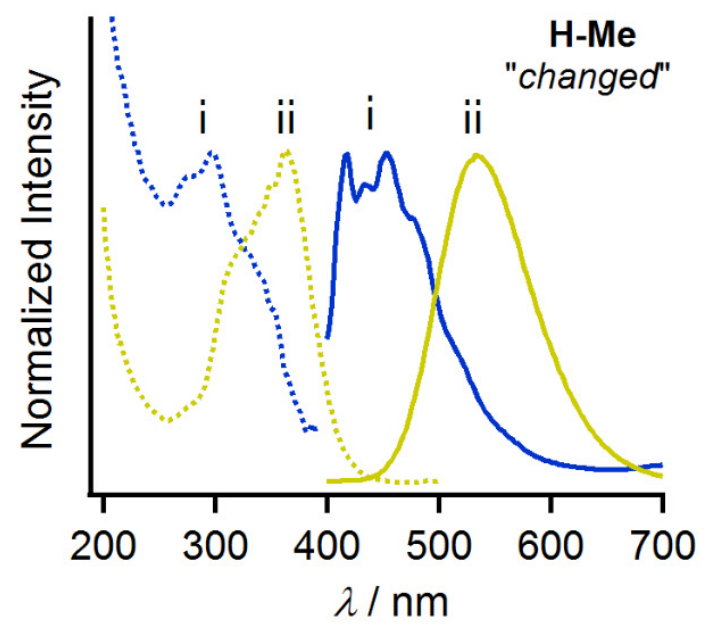

d)

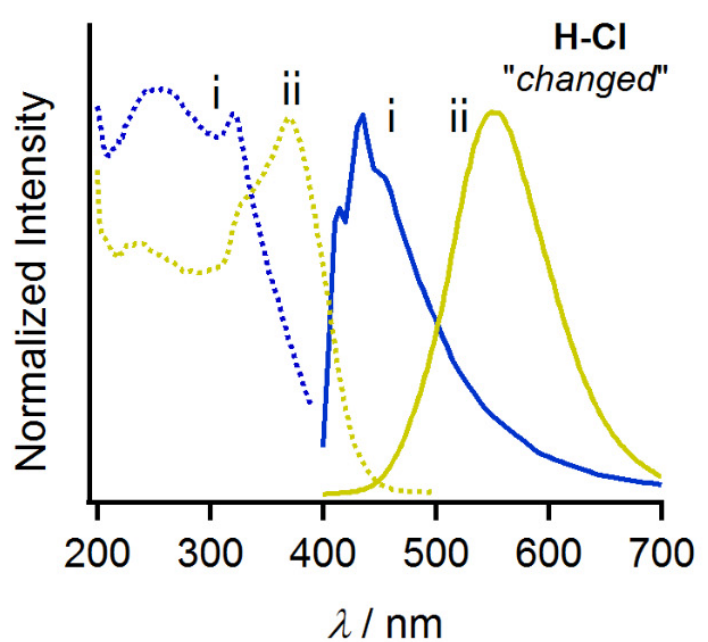

f)

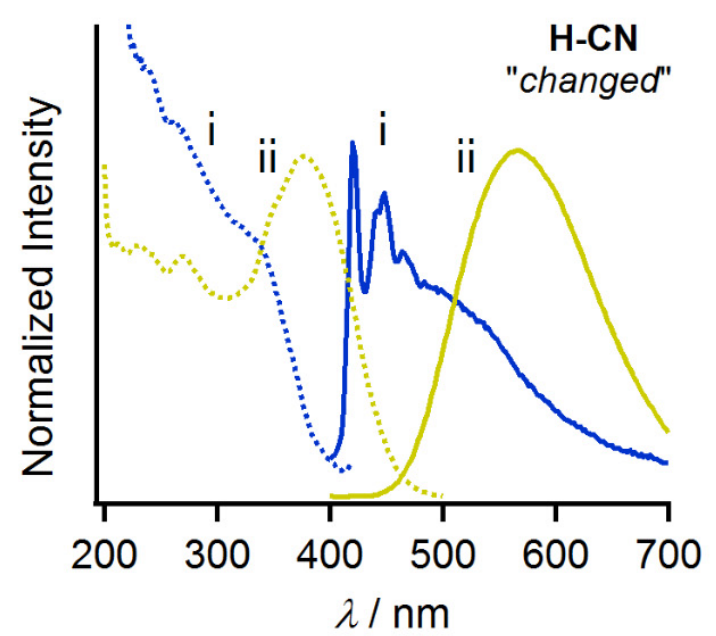

Figure S3. Excitation (dotted lines) and emission spectra (solid lines) of as-prepared (denoted as "i") and ground phases (denoted as "ii") of a) H-OMe, b) $\mathbf{H}-\mathbf{M e}$, c) $\mathbf{H}-\mathbf{H},{ }^{\mathrm{S} 7}$ d) $\mathbf{H}-\mathbf{C l}$, e) $\mathbf{H}-\mathbf{C F}_{\mathbf{3}}$, and f) H-CN. The measurement conditions are summarized in Table S1. 
a)

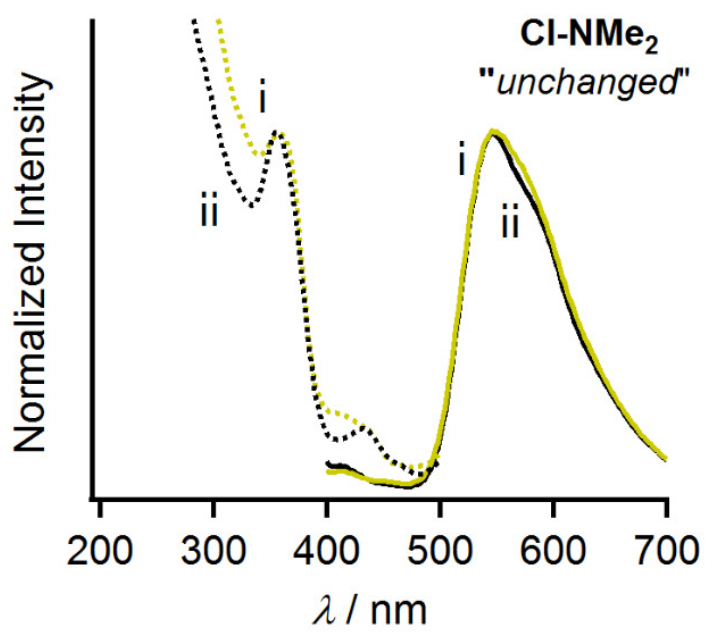

c)

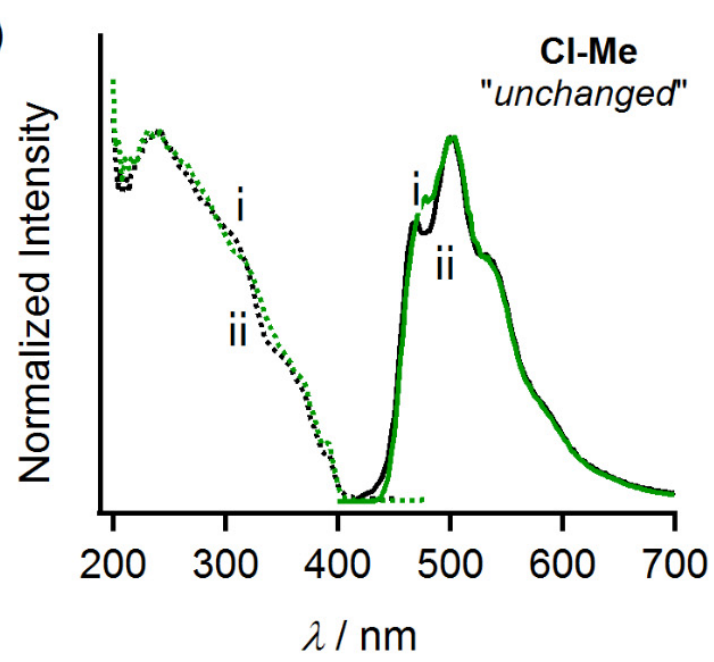

e)

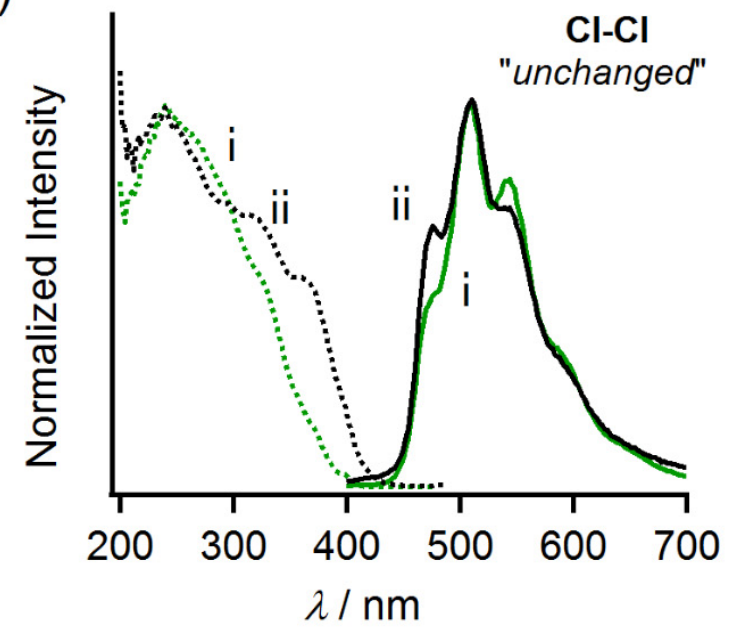

b)

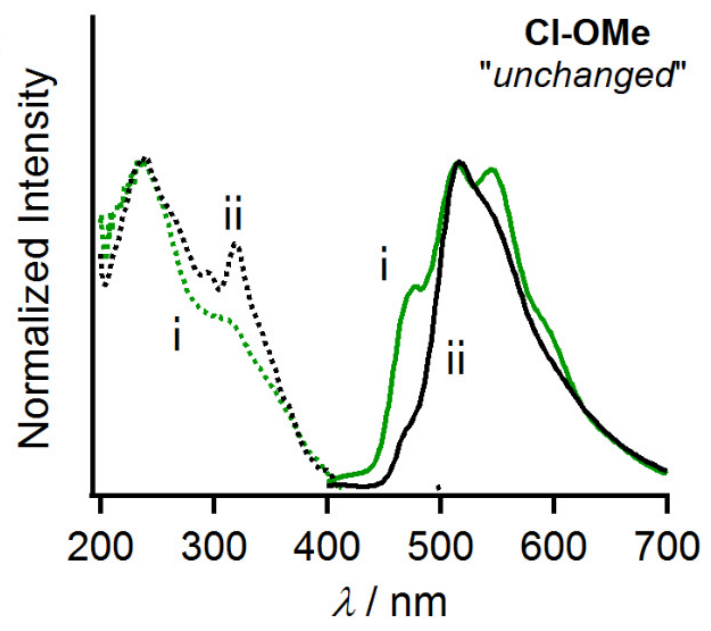

d)

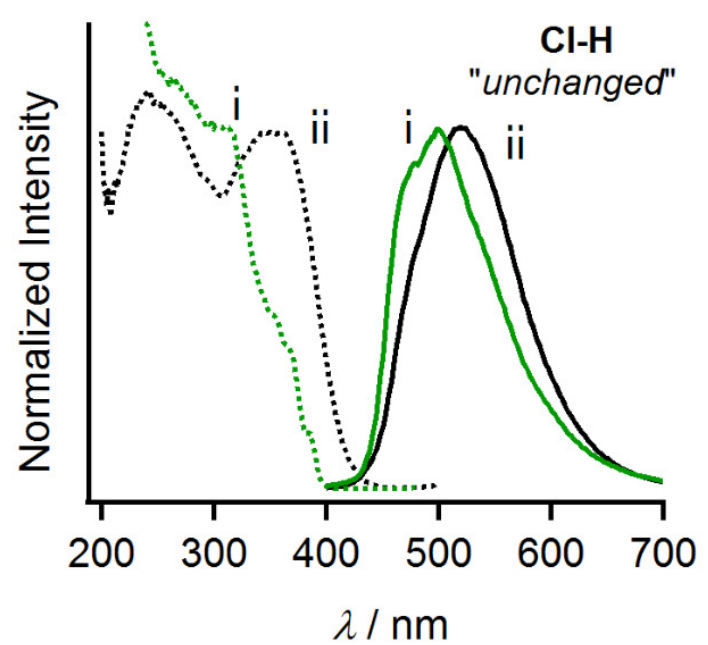

f)

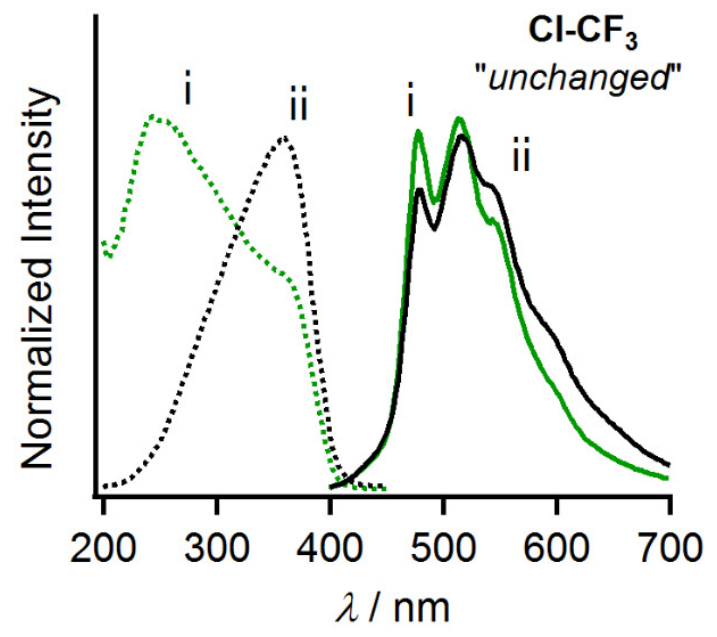




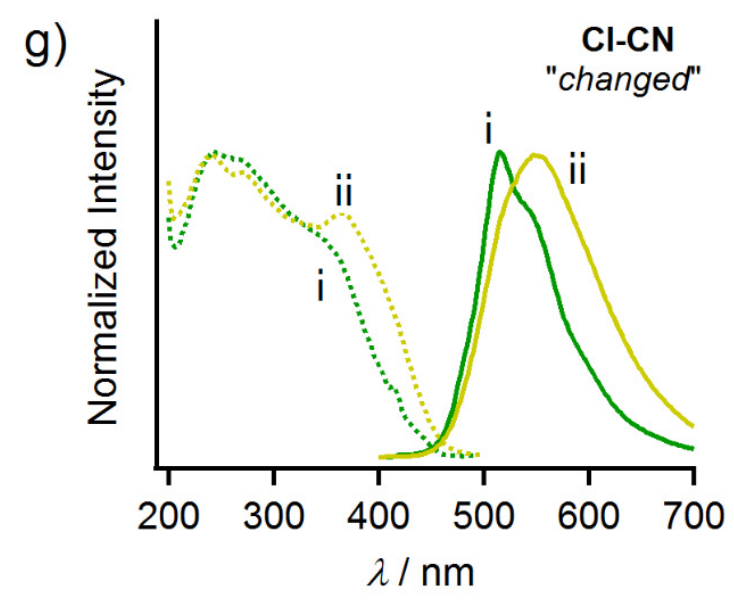

Figure S4. Excitation (dotted lines) and emission spectra (solid lines) of as-prepared (denoted as "i") and ground phases (denoted as "ii") of a) $\mathrm{Cl}_{-} \mathrm{NMe}_{2}$, b) Cl-OMe, c) $\mathbf{C l}-\mathbf{M e}$, d) Cl-H, e) Cl-Cl, f) $\mathbf{C l}-\mathbf{C F}_{3}$, and g) $\mathbf{C l}-\mathbf{C N}$. The measurement conditions are summarized in Table S1. 
a)

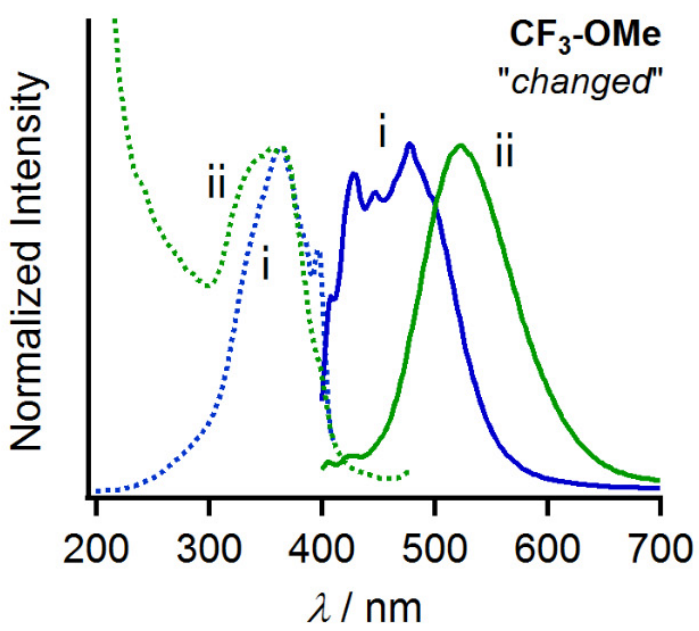

C)

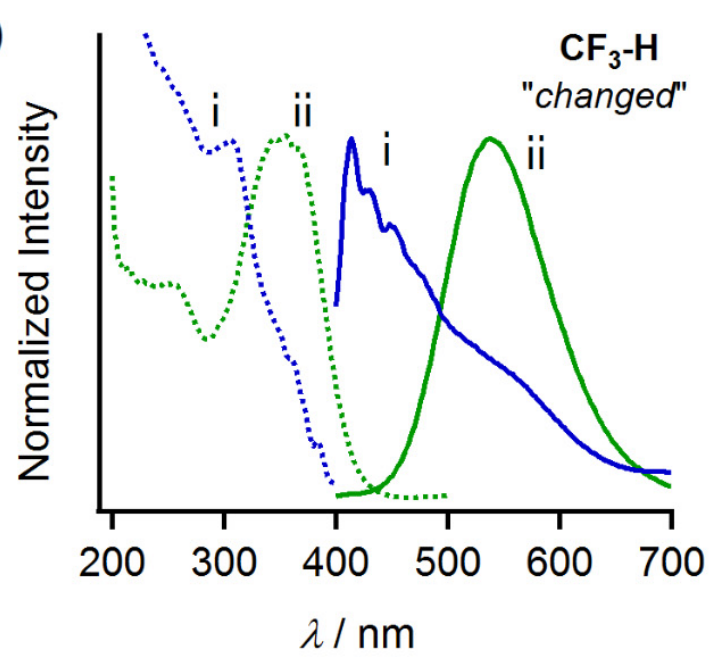

e)

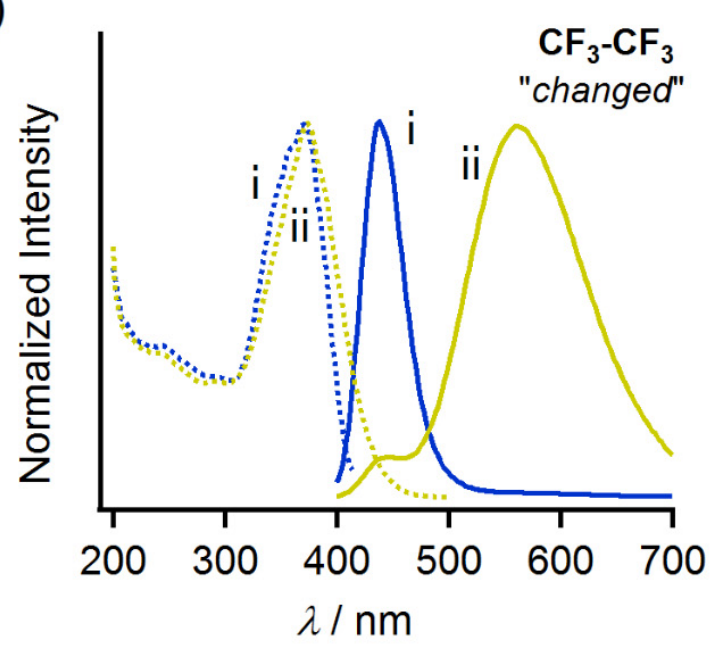

b)

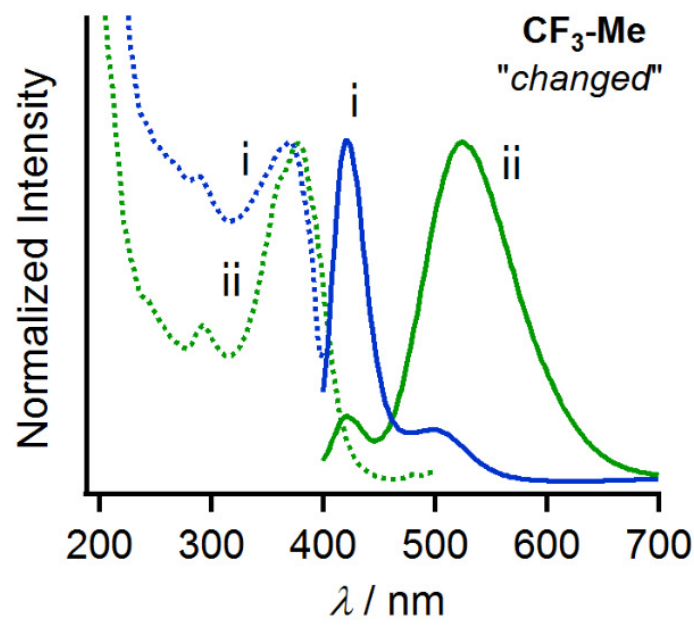

d)

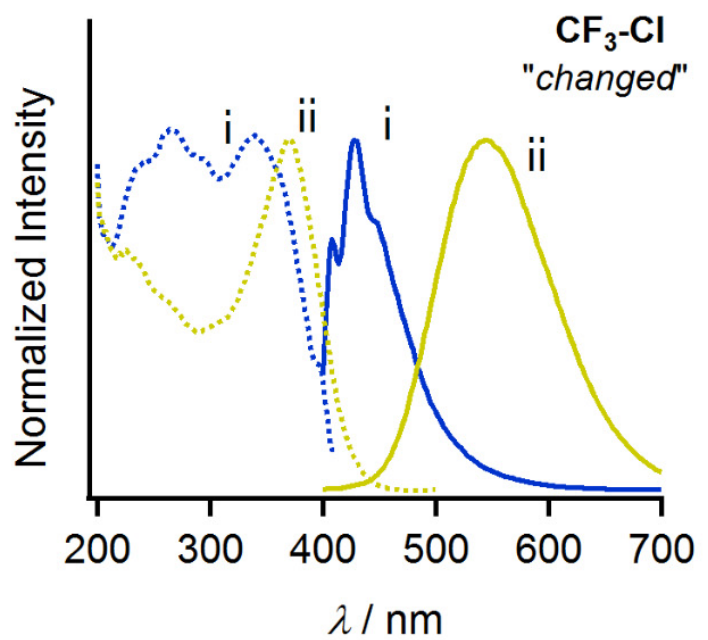

f)

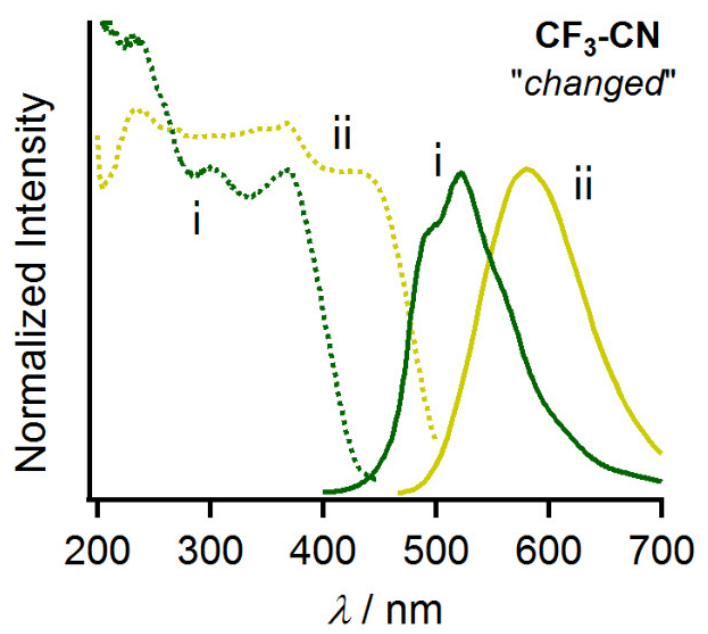

Figure S5. Excitation (dotted lines) and emission spectra (solid lines) of as-prepared (denoted as "i") and ground phases (denoted as "ii") of a) $\mathbf{C F}_{\mathbf{3}}-\mathbf{O M e}$, b) $\mathbf{C F}_{\mathbf{3}}-\mathbf{M e}$, c) $\mathbf{C F}_{\mathbf{3}}-\mathbf{H}$, d) $\mathbf{C F}_{\mathbf{3}}-\mathbf{C l}$, e) $\mathbf{C F}_{\mathbf{3}}-\mathbf{C F}_{\mathbf{3}}$, and f) $\mathbf{C F}_{3}-\mathbf{C N}$. The measurement conditions are summarized in Table S1. 
a)

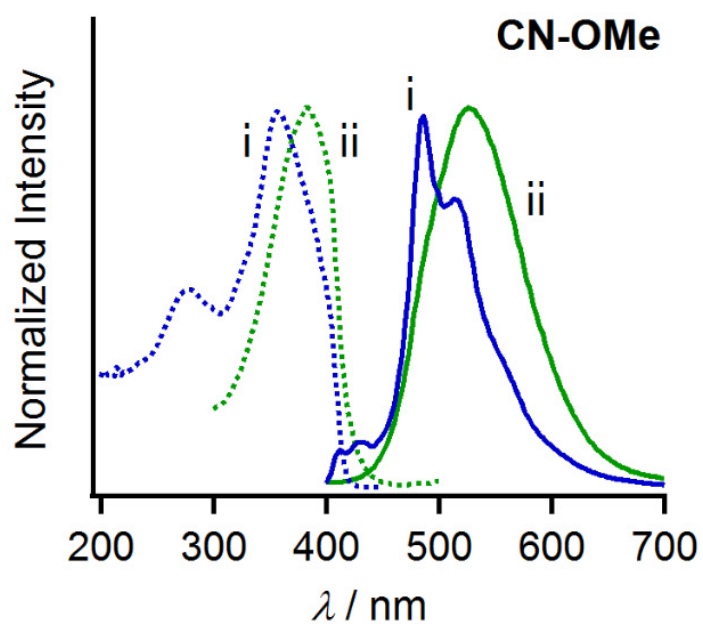

c)

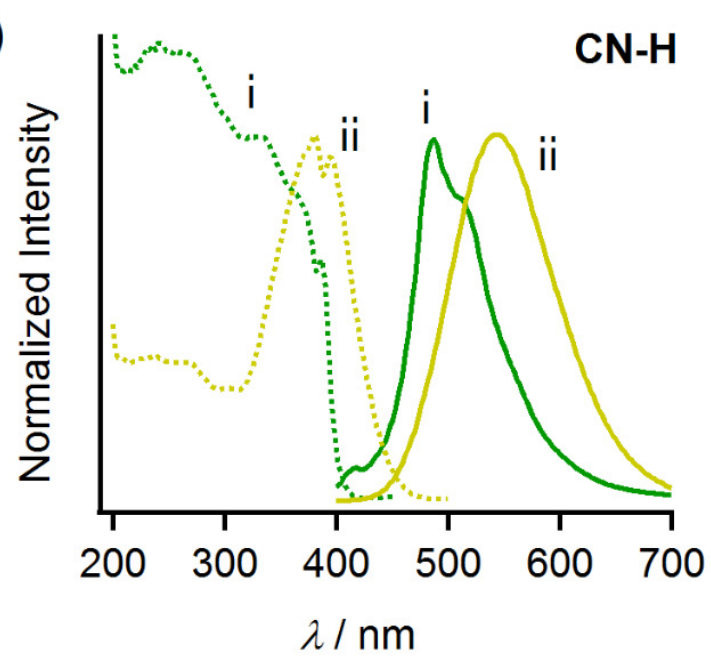

e)

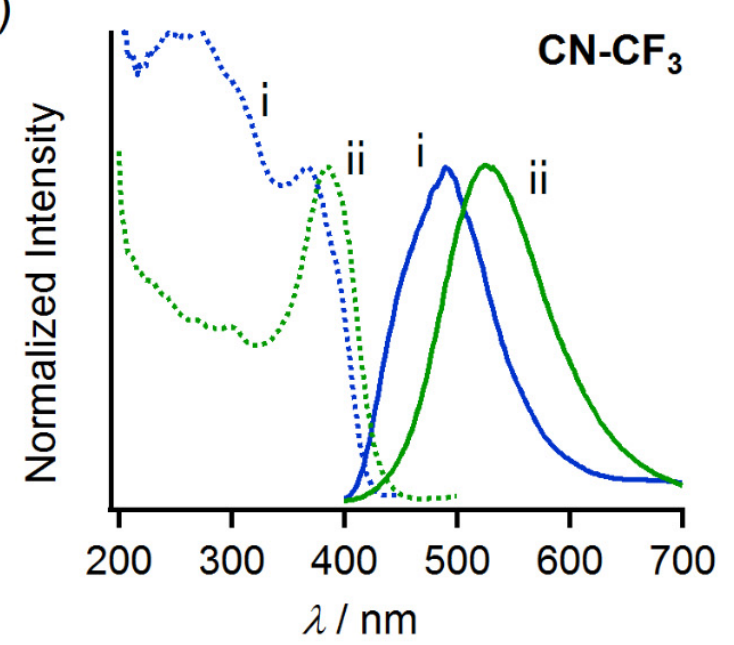

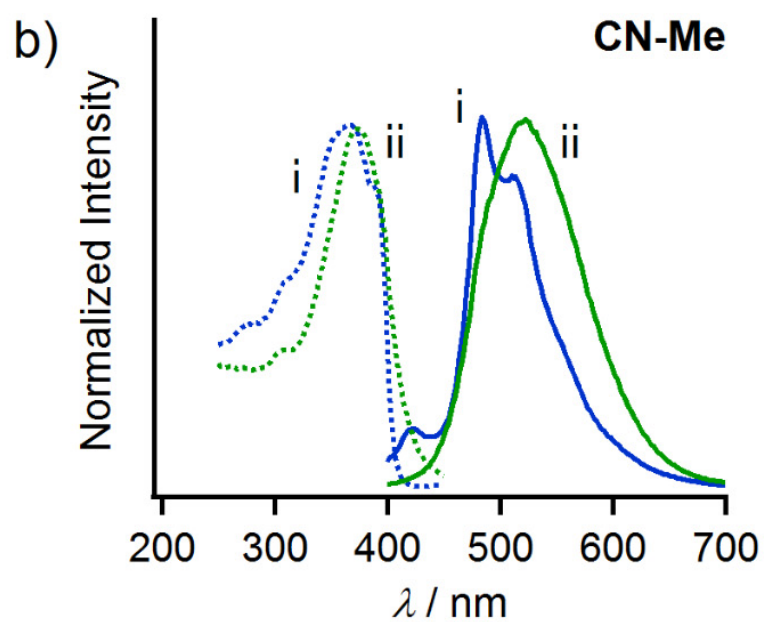

d)

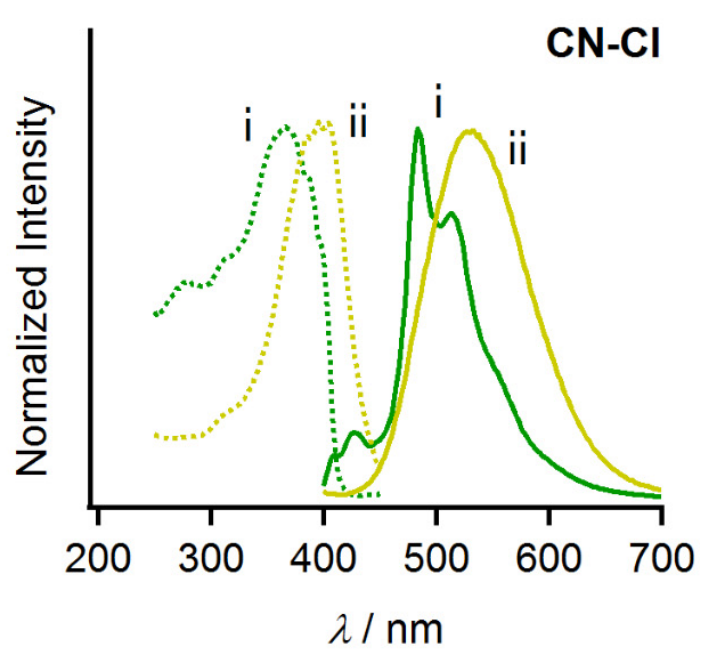

f)

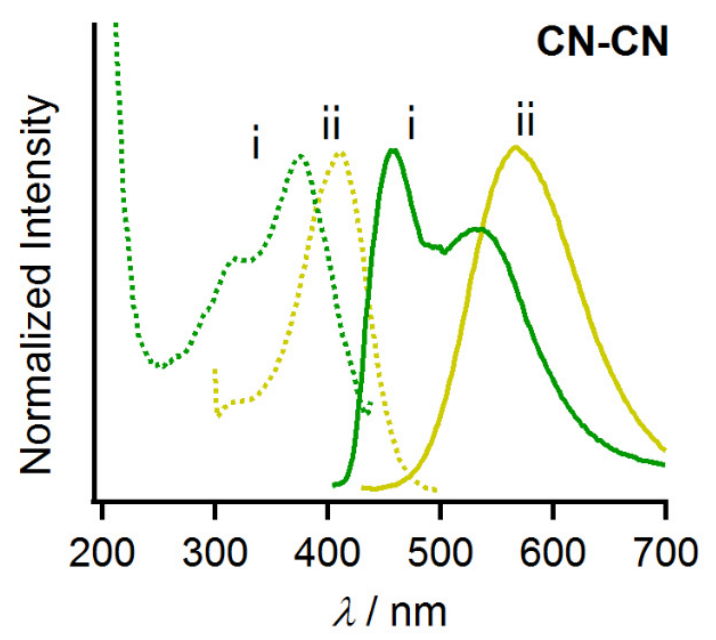

Figure S6. Excitation (dotted lines) and emission spectra (solid lines) of as-prepared (denoted as "i") and ground phases (denoted as "ii") of a) $\mathbf{C N}-\mathbf{O M e}$, b) $\mathbf{C N}-\mathrm{Me}$, c) $\mathbf{C N}-\mathbf{H}$, d) $\mathbf{C N}-\mathbf{C l}$, e) $\mathbf{C N}-\mathbf{C F}_{3}$, and f) CN-CN. The measurement conditions are summarized in Table S1. 
Table S1. Summary of the measurement conditions for the excitation and emission spectra shown in Fig S1-S6.

\begin{tabular}{|c|c|c|c|c|c|}
\hline Figure & Complexes & $\begin{array}{l}\text { Monitored } \\
\text { emission } \\
\text { wavelength of the } \\
\text { as-prepared phases } \\
/ \mathrm{nm} \\
\end{array}$ & $\begin{array}{l}\text { Monitored } \\
\text { emission } \\
\text { wavelength of the } \\
\text { ground phases / } \\
\text { nm }\end{array}$ & $\begin{array}{l}\text { Excitation } \\
\text { wavelength of the } \\
\text { as-prepared phases } \\
/ \mathrm{nm}\end{array}$ & $\begin{array}{l}\text { Excitation } \\
\text { wavelength of the } \\
\text { ground phases / } \\
\mathrm{nm}\end{array}$ \\
\hline Figure S1 a) & OMe-OMe & 495 & 495 & 310 & 310 \\
\hline Figure S1 b) & ОМе-Ме & 499 & 505 & 365 & 365 \\
\hline Figure S1 c) & OMe-H & 466 & 498 & 365 & 365 \\
\hline Figure S1 d) & OMe-CI & 510 & 525 & 365 & 365 \\
\hline Figure S1 e) & $\mathrm{OMe}_{-} \mathrm{CF}_{3}$ & 470 & 535 & 365 & 365 \\
\hline Figure S1 f) & OMe-CN & 531 & 592 & 365 & 409 \\
\hline Figure S2 a) & Мe-OMe & 420 & 513 & 365 & 365 \\
\hline Figure S2 b) & Me-Me & 460 & 505 & 365 & 365 \\
\hline Figure S2 c) & Мe-H & 482 & 532 & 365 & 365 \\
\hline Figure S2 d) & Me-Cl & 566 & 515 & 365 & 365 \\
\hline Figure S2 e) & $\mathrm{Me}-\mathrm{CF}_{3}$ & 590 & 555 & 365 & 365 \\
\hline Figure $S 2 \mathrm{f}$ ) & Me-CN & 450 & 461 & 365 & 386 \\
\hline Figure S3 a) & H-OMe & 429 & 522 & 365 & 365 \\
\hline Figure S3 b) & H-Me & 417 & 535 & 365 & 365 \\
\hline Figure S3 c) & $\mathbf{H}-\mathbf{H}^{\mathrm{S} 7}$ & 488 & 565 & 365 & 385 \\
\hline Figure S3 d) & $\mathrm{H}-\mathrm{Cl}$ & 412 & 551 & 365 & 365 \\
\hline Figure S3 e) & $\mathrm{H}-\mathrm{CF}_{3}$ & 468 & 558 & 365 & 365 \\
\hline Figure S3 f) & $\mathrm{H}-\mathrm{CN}$ & 448 & 559 & 241 & 376 \\
\hline Figure S4 a) & $\mathrm{Cl}-\mathrm{NMe}_{2}$ & 546 & 546 & 365 & 365 \\
\hline Figure S4 b) & Cl-OMe & 514 & 518 & 365 & 365 \\
\hline Figure S4 c) & Cl-Me & 502 & 473 & 240 & 240 \\
\hline Figure S4 d) & Cl-H & 510 & 519 & 328 & 365 \\
\hline Figure S4 e) & $\mathrm{Cl}-\mathrm{Cl}$ & 510 & 513 & 240 & 241 \\
\hline Figure S4 f) & $\mathrm{Cl}-\mathrm{CF}_{3}$ & 479 & 515 & 240 & 365 \\
\hline Figure S5 g) & Cl-CN & 515 & 550 & 365 & 365 \\
\hline Figure S5 a) & $\mathrm{CF}_{3}-\mathrm{OMe}$ & 429 & 520 & 365 & 365 \\
\hline Figure S5 b) & $\mathrm{CF}_{3}-\mathrm{Me}$ & 420 & 525 & 365 & 365 \\
\hline Figure S5 c) & $\mathrm{CF}_{3}-\mathrm{H}$ & 448 & 525 & 365 & 365 \\
\hline Figure S5 d) & $\mathrm{CF}_{3}-\mathrm{Cl}$ & 425 & 545 & 365 & 365 \\
\hline Figure S5 e) & $\mathrm{CF}_{3}-\mathrm{CF}_{3}$ & 435 & 565 & 365 & 365 \\
\hline Figure S5 f) & $\mathrm{CF}_{3}-\mathrm{CN}$ & 522 & 582 & 365 & 365 \\
\hline Figure S6 a) & CN-OMe & 485 & 525 & 360 & 380 \\
\hline Figure S6 b) & CN-Me & 448 & 521 & 365 & 370 \\
\hline Figure S6 c) & $\mathrm{CN}-\mathrm{H}$ & 490 & 545 & 365 & 365 \\
\hline Figure S6 d) & CN-Cl & 484 & 537 & 365 & 385 \\
\hline Figure S6 e) & $\mathrm{CN}-\mathrm{CF}_{3}$ & 490 & 525 & 365 & 365 \\
\hline Figure S6 f) & $\mathrm{CN}-\mathrm{CN}$ & 456 & 567 & 372 & 410 \\
\hline
\end{tabular}




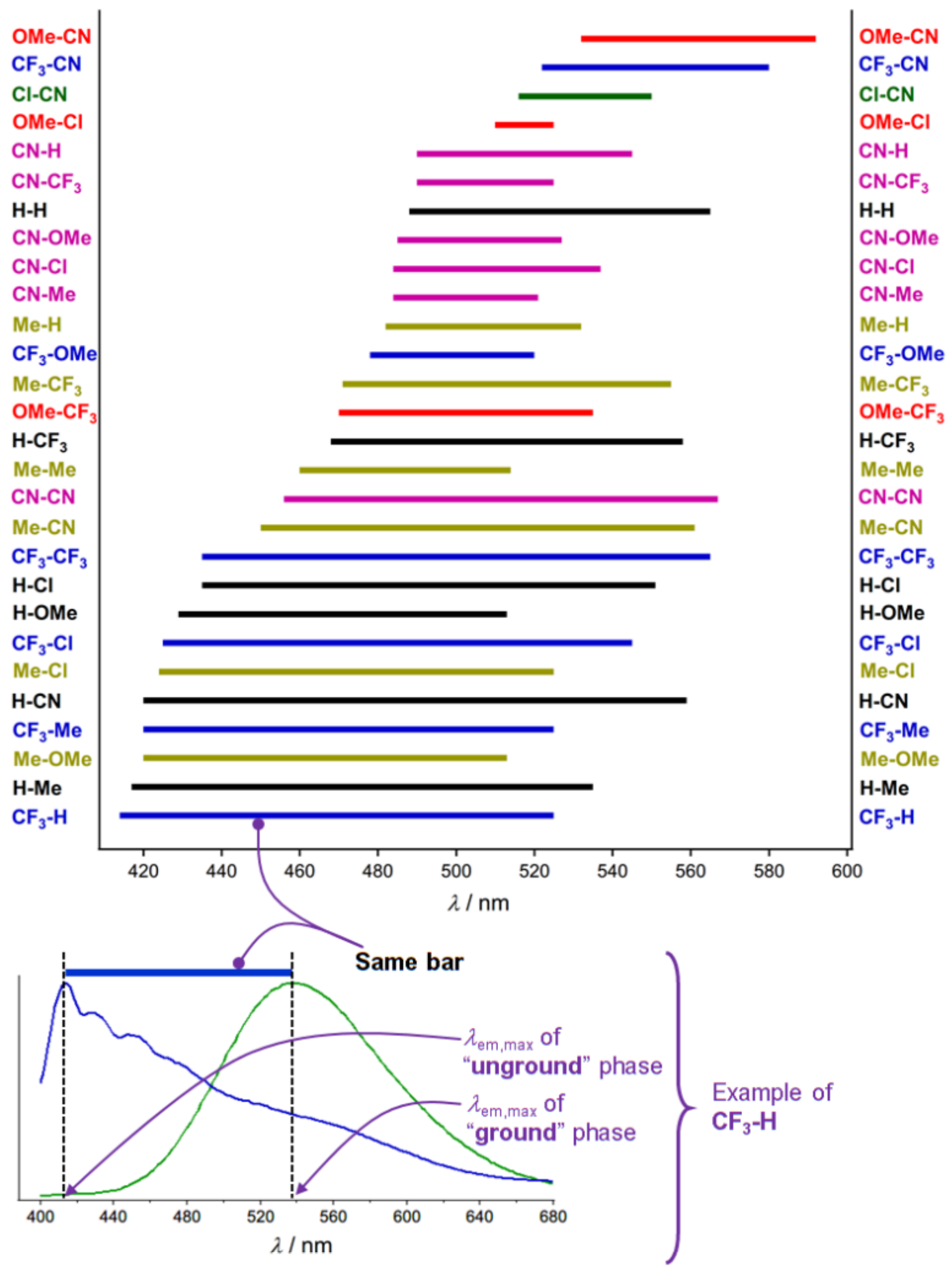

Figure S7. Changes in emission maximum wavelength $\left(\lambda_{\mathrm{em}, \max }\right)$ of $28 \mathbf{R}^{\mathbf{1}}-\mathbf{R}^{\mathbf{2}}$ complexes upon mechanical stimulation. Left and right apexes of each bar represent $\lambda_{\mathrm{em} \text {,max }}$ of unground and ground forms of $\mathbf{R}^{\mathbf{1}}-\mathbf{R}^{\mathbf{2}}$ (see an example of $\mathbf{C} \mathbf{F}_{\mathbf{3}}-\mathbf{H}$, bottom). 


\section{Preparation of the Single Crystals of $\mathbf{R}^{1}-\mathbf{R}^{2}$}

Table S2. Photographs of 28 mechanochromic $\mathbf{R}^{\mathbf{1}}-\mathbf{R}^{\mathbf{2}}$ complexes under UV illumination. In each panel, unground powders and single crystals are placed at the left and right sides, respectively. Very slender crystals of $\mathbf{C N}-\mathbf{H}$, which is unsuitable for singe crystal X-ray diffraction analyses, were shown in an orange rectangle (only this photograph is taken under room light).

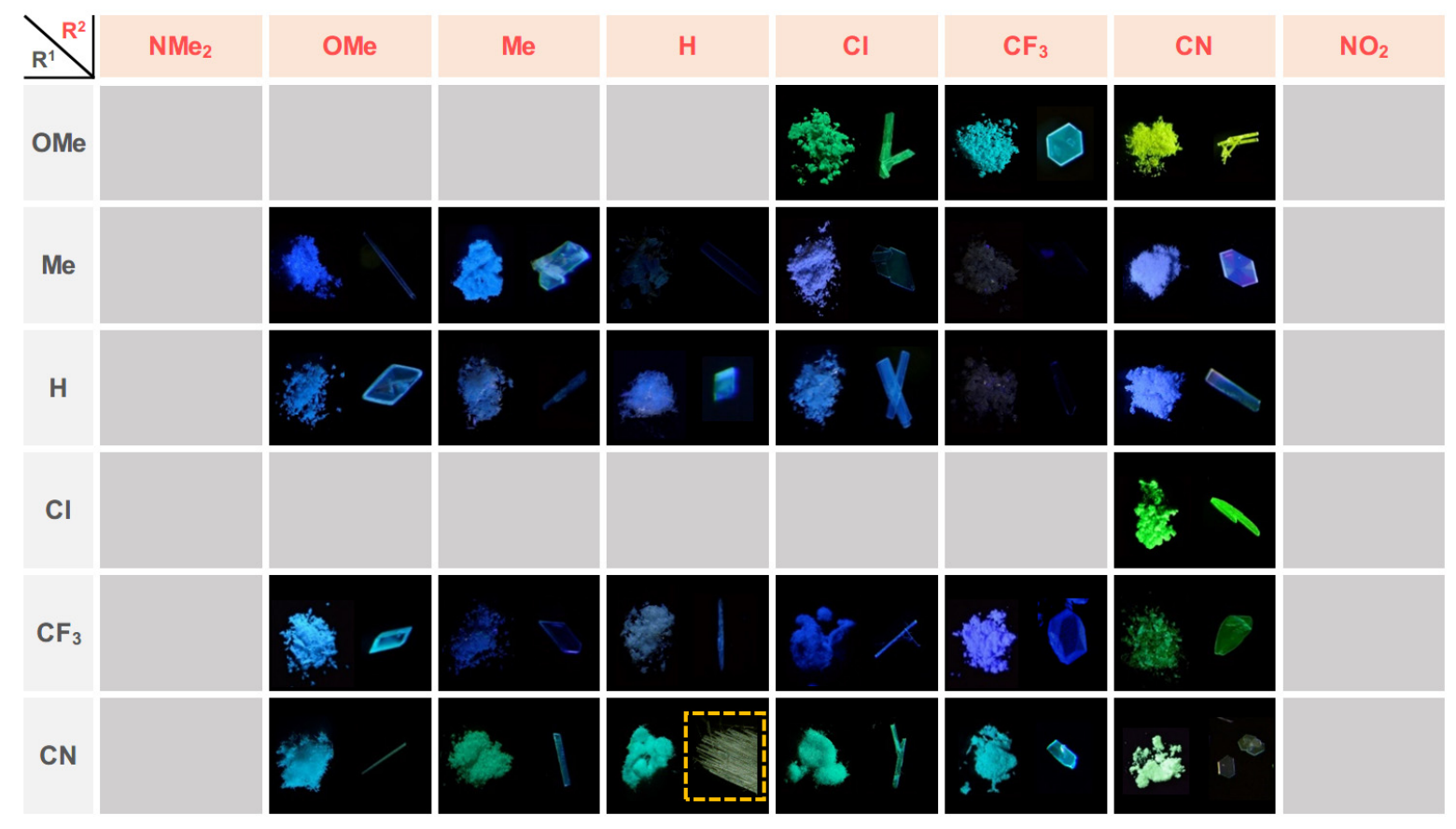


Table S3. Crystal data for twenty-seven $R^{1}-R^{2}$ complexes including the polymorphs of $C_{3}-C N$.

\begin{tabular}{|c|c|c|c|c|c|}
\hline compound & OMe-Cl & $\mathrm{OMe}-\mathrm{CF}_{3}$ & $\mathrm{OMe}-\mathrm{CN}$ & Мe-OMe & Me-Me \\
\hline CCDC Number & CCDC 1454130 & CCDC 1454132 & CCDC 1454133 & CCDC 1454134 & CCDC 1454135 \\
\hline Empirical Formula & $\mathrm{C}_{14} \mathrm{H}_{11} \mathrm{AuClNO}$ & $\mathrm{C}_{15} \mathrm{H}_{11} \mathrm{AuF}_{3} \mathrm{NO}$ & $\mathrm{C}_{15} \mathrm{H}_{11} \mathrm{AuN}_{2} \mathrm{O}$ & $\mathrm{C}_{15} \mathrm{H}_{14} \mathrm{AuNO}$ & $\mathrm{C}_{15} \mathrm{H}_{14} \mathrm{AuN}$ \\
\hline Formula Weight & 441.67 & 475.22 & 432.23 & 421.25 & 405.25 \\
\hline Crystal System & triclinic & monoclinic & monoclinic & triclinic & triclinic \\
\hline Crystal Size / mm & $0.126 \times 0.053 \times 0.042$ & $0.245 \times 0.114 \times 0.059$ & $0.186 \times 0.080 \times 0.043$ & $0.473 \times 0.179 \times 0.100$ & $0.494 \times 0.141 \times 0.043$ \\
\hline$a / \AA$ & $6.8740(8)$ & $7.3678(8)$ & $6.9906(6)$ & $6.6950(5)$ & $6.3659(6)$ \\
\hline$b / \AA$ & $7.0599(9)$ & $24.337(3)$ & $29.526(3)$ & $8.4033(6)$ & $8.6330(9)$ \\
\hline$c / \AA$ & $14.674(2)$ & $8.511(1)$ & $6.8859(5)$ & $12.543(1)$ & $12.3108(12)$ \\
\hline$\alpha /^{\circ}$ & $94.164(4)$ & 90 & 90 & $79.091(2)$ & $81.766(3)$ \\
\hline$\beta /^{\circ}$ & $95.984(3)$ & $114.203(3)$ & $114.200(7)$ & $83.512(3)$ & $79.192(3)$ \\
\hline$\gamma /^{\circ}$ & $114.653(3)$ & 90 & 90 & $75.486(2)$ & $76.777(3)$ \\
\hline$V / \AA^{3}$ & $638.36(14)$ & $1392.0(3)$ & $1296.4(2)$ & $669.20(8)$ & $643.37(11)$ \\
\hline Space Group & $P-1(\# 2)$ & $P 2_{1} / n(\# 14)$ & $P 2_{1} / c(\# 14)$ & $P-1(\# 2)$ & $P-1(\# 2)$ \\
\hline$Z$ value & 2 & 4 & 4 & 2 & 2 \\
\hline$D_{\text {calc }} / \mathrm{g} \mathrm{cm}^{-3}$ & 2.298 & 2.267 & 2.214 & 2.090 & 2.092 \\
\hline Temperature / K & 123 & 123 & 123 & 123 & 123 \\
\hline $2 \theta_{\max } /^{\circ}$ & 50.1 & 55.0 & 54.9 & 54.8 & 55.0 \\
\hline$\mu\left(\mathrm{Mo} \mathrm{K}_{\alpha}\right) / \mathrm{cm}^{-1}$ & 117.569 & 106.365 & 113.792 & 110.168 & 114.490 \\
\hline \multirow[t]{3}{*}{ No. of Reflections } & Total: 4940 & Total: 13286 & Total: 12531 & Total: 6519 & Total: 6393 \\
\hline & Unique: 2186 & Unique: 3181 & Unique: 2948 & Unique: 3018 & Unique: 2928 \\
\hline & $R_{\text {int }}=0.1262$ & $R_{\text {int }}=0.1519$ & $R_{\text {int }}=0.1033$ & $R_{\text {int }}=0.0765$ & $R_{\text {int }}=0.0926$ \\
\hline$R_{1}{ }^{\mathrm{a}}$ & 0.0965 & 0.0927 & 0.0436 & 0.0530 & 0.0620 \\
\hline$w R_{2}^{\mathrm{b}}$ & 0.3226 & 0.2446 & 0.1575 & 0.1301 & 0.1669 \\
\hline $\mathrm{GOF}^{c}$ & 1.159 & 1.048 & 0.910 & 1.050 & 1.104 \\
\hline Max./Mini. peak $I^{\mathrm{d}} / \AA^{3}$ & $3.09 \mathrm{e}^{-} /-5.30 \mathrm{e}^{-}$ & $4.18 \mathrm{e}^{-} /-3.03 \mathrm{e}^{-}$ & $2.42 \mathrm{e}^{-} /-2.05 \mathrm{e}^{-}$ & $5.36 \mathrm{e}^{-} /-2.46 \mathrm{e}^{-}$ & $1.99 \mathrm{e}^{-} /-2.40 \mathrm{e}^{-}$ \\
\hline compound & Ме-H & Me-Cl & $\mathrm{Me}-\mathrm{CF}_{3}$ & $\mathrm{Me}-\mathrm{CN}$ & H-OMe \\
\hline CCDC Number & CCDC 1454136 & CCDC 1454137 & CCDC 1454138 & CCDC 1454139 & CCDC 1454140 \\
\hline Empirical Formula & $\mathrm{C}_{14} \mathrm{H}_{12} \mathrm{AuN}$ & $\mathrm{C}_{14} \mathrm{H}_{11} \mathrm{AuClN}$ & $\mathrm{C}_{15} \mathrm{H}_{11} \mathrm{AuF}_{3} \mathrm{~N}$ & $\mathrm{C}_{15} \mathrm{H}_{11} \mathrm{AuN}_{2}$ & $\mathrm{C}_{14} \mathrm{H}_{12} \mathrm{AuNO}$ \\
\hline Formula Weight & 391.22 & 425.67 & 459.22 & 416.23 & 407.22 \\
\hline Crystal System & $0.185 \times 0.154 \times 0.132$ & $0.137 \times 0.059 \times 0.033$ & $0.220 \times 0.071 \times 0.045$ & $0.182 \times 0.172 \times 0.074$ & $0.391 \times 0.280 \times 0.173$ \\
\hline Crystal Size / mm & triclinic & triclinic & triclinic & triclinic & triclinic \\
\hline$a / \AA$ & $7.2547(6)$ & $6.3486(6)$ & $6.4203(9)$ & $6.4140(6)$ & $6.3043(5)$ \\
\hline$b / \AA$ & $9.7720(9)$ & $7.1582(8)$ & $7.272(1)$ & $6.9053(6)$ & $8.6471(8)$ \\
\hline$c / \AA$ & $10.111(1)$ & $14.005(2)$ & $14.555(2)$ & $14.350(2)$ & $12.2827(11)$ \\
\hline$\alpha /^{\circ}$ & $73.005(3)$ & $90.925(4)$ & $92.931(4)$ & $94.307(3)$ & $99.9493(19)$ \\
\hline$\beta /^{\circ}$ & $66.096(3)$ & $99.120(4)$ & $98.361(4)$ & $91.801(3)$ & $93.202(2)$ \\
\hline$\gamma /^{\circ}$ & $71.153(3)$ & $97.035(3)$ & $97.877(4)$ & $90.606(3)$ & $103.6865(19)$ \\
\hline$V / \AA^{3}$ & $609.27(9)$ & $623.3(2)$ & $664.2(2)$ & $633.4(1)$ & $637.50(10)$ \\
\hline Space Group & $P-1(\# 2)$ & $P-1(\# 2)$ & $P-1(\# 2)$ & $P-1(\# 2)$ & $P-1(\# 2)$ \\
\hline$Z$ value & 2 & 2 & 2 & 2 & 2 \\
\hline$D_{\text {calc }} / \mathrm{g} \mathrm{cm}^{-3}$ & 2.132 & 2.268 & 2.296 & 2.182 & 2.121 \\
\hline Temperature / K & 123 & 123 & 123 & 123 & 123 \\
\hline $2 \theta_{\max } /^{\circ}$ & 55.0 & 55.0 & 55.0 & 54.9 & 54.9 \\
\hline$\mu\left(\mathrm{Mo} \mathrm{K}_{\alpha}\right) / \mathrm{cm}^{-1}$ & 120.856 & 120.312 & 111.351 & 116.345 & 115.606 \\
\hline \multirow[t]{3}{*}{ No. of Reflections } & Total: 6044 & Total: 6072 & Total: 5252 & Total: 6254 & Total: 6245 \\
\hline & Unique: 2769 & Unique: 2804 & Unique: 2356 & Unique: 2865 & Unique: 2888 \\
\hline & $R_{\text {int }}=0.0585$ & $R_{\mathrm{int}}=0.1215$ & $R_{\mathrm{int}}=0.1086$ & $R_{\mathrm{int}}=0.0499$ & $R_{\mathrm{int}}=0.1020$ \\
\hline$R_{1}^{\mathrm{a}}$ & 0.0361 & 0.0917 & 0.0949 & 0.0326 & 0.0706 \\
\hline$w R_{2}{ }^{\mathrm{b}}$ & 0.1204 & 0.2604 & 0.2623 & 0.0825 & 0.1773 \\
\hline $\mathrm{GOF}^{c}$ & 0.856 & 1.175 & 1.120 & 0.993 & 1061 \\
\hline Max./Mini. peak $I^{\mathrm{d}} / \AA^{3}$ & $2.26 \mathrm{e}^{-/}-1.68 \mathrm{e}^{-}$ & $3.54 \mathrm{e}^{-/}-5.42 \mathrm{e}^{-}$ & $2.56 \mathrm{e}^{-} /-5.71 \mathrm{e}^{-}$ & $3.20 \mathrm{e}^{-} /-2.63 \mathrm{e}^{-}$ & $4.05 \mathrm{e}^{-/}-3.99 \mathrm{e}^{-}$ \\
\hline
\end{tabular}

${ }^{\mathrm{a}}: I>2.00 \sigma(I) .{ }^{\mathrm{b}}:$ All reflections. ${ }^{\mathrm{c}}$ :Goodness of Fit Indicator. ${ }^{\mathrm{d}}$ :in Final Diff. Map. 


\begin{tabular}{|c|c|c|c|c|c|}
\hline compound & H-Me & $\mathrm{H}-\mathrm{Cl}$ & $\mathrm{H}-\mathrm{CF}_{3}$ & $\mathrm{H}-\mathrm{CN}$ & $\mathrm{Cl}-\mathrm{CN}$ \\
\hline CCDC Number & CCDC 1454141 & CCDC 1454142 & CCDC 1454143 & CCDC 1454144 & CCDC 1454145 \\
\hline Empirical Formula & $\mathrm{C}_{14} \mathrm{H}_{12} \mathrm{AuN}$ & $\mathrm{C}_{13} \mathrm{H}_{9} \mathrm{AuClN}$ & $\mathrm{C}_{14} \mathrm{H}_{9} \mathrm{AuF}_{3} \mathrm{~N}$ & $\mathrm{C}_{14} \mathrm{H}_{9} \mathrm{AuN}_{2}$ & $\mathrm{C}_{14} \mathrm{H}_{8} \mathrm{AuClN}{ }_{2}$ \\
\hline Formula Weight & 391.22 & 411.64 & 445.19 & 402.20 & 436.65 \\
\hline Crystal System & monoclinic & triclinic & triclinic & triclinic & triclinic \\
\hline Crystal Size / nm & $0.404 \times 0.114 \times 0.062$ & $0.494 \times 0.141 \times 0.043$ & $0.286 \times 0.243 \times 0.042$ & $0.169 \times 0.038 \times 0.002$ & $0.137 \times 0.032 \times 0.028$ \\
\hline$a / \AA$ & $18.156(3)$ & $6.3496(4)$ & $6.215(2)$ & $6.9202(15)$ & $6.8906(10)$ \\
\hline$b / \AA$ & $6.5347(9)$ & $7.3532(4)$ & $7.350(2)$ & $7.1410(14)$ & $7.1130(12)$ \\
\hline$c / \AA$ & $21.482(3)$ & $25.135(2)$ & $14.248(3)$ & $13.325(3)$ & $13.5215(19)$ \\
\hline$\alpha /^{\circ}$ & 90 & $85.884(2)$ & $104.344(9)$ & $92.849(5)$ & $78.534(4)$ \\
\hline$\beta /^{\circ}$ & $103.933(4)$ & $86.114(2)$ & $99.413(5)$ & $94.527(5)$ & $79.875(3)$ \\
\hline$\gamma /{ }^{\circ}$ & 90 & $82.986(2)$ & $91.364(5)$ & $113.429(5)$ & $70.245(4)$ \\
\hline$V / \AA^{3}$ & $2473.7(6)$ & $1159.7(2)$ & $620.6(2)$ & $599.9(2)$ & $607.03(16)$ \\
\hline Space Group & $C 2 / c(\# 15)$ & $P-1(\# 2)$ & $P-1(\# 2)$ & $P-1(\# 2)$ & $P-1(\# 2)$ \\
\hline$Z$ value & 8 & 4 & 2 & 2 & 2 \\
\hline Temperature / K & 123 & 123 & 123 & 289 & 123 \\
\hline $2 \theta_{\max } /^{\circ}$ & 54.9 & 55.0 & 54.9 & 54.9 & 50.1 \\
\hline$\mu\left(\mathrm{Mo} \mathrm{K}_{\alpha}\right) / \mathrm{cm}^{-1}$ & 119.067 & 129.274 & 119.134 & 122.795 & 123.590 \\
\hline \multirow[t]{3}{*}{ No. of Reflections } & Total: 11367 & Total: 11346 & Total: 6095 & Total: 5807 & Total: 4840 \\
\hline & Unique: 2833 & Unique: 5261 & Unique: 2818 & Unique: 2696 & Unique: 2155 \\
\hline & $R_{\mathrm{int}}=0.0868$ & $R_{\text {int }}=0.0908$ & $R_{\mathrm{int}}=0.0966$ & $R_{\mathrm{int}}=0.0874$ & $R_{\text {int }}=0.1204$ \\
\hline$R_{1}{ }^{\mathrm{a}}$ & 0.0671 & 0.0657 & 0.0749 & 0.0723 & 0.0936 \\
\hline$w R_{2}{ }^{\mathrm{b}}$ & 0.3158 & 0.1670 & 0.1896 & 0.2059 & 0.2946 \\
\hline $\mathrm{GOF}^{c}$ & 0.865 & 0.823 & 1.072 & 1.016 & 1.174 \\
\hline Max./Mini. peak $I^{\mathrm{d}} / \AA^{3}$ & $3.65 \mathrm{e}^{-} /-2.84 \mathrm{e}^{-}$ & $4.57 \mathrm{e}^{-} /-4.72 \mathrm{e}^{-}$ & $4.25 \mathrm{e}^{-} /-4.80 \mathrm{e}^{-}$ & $2.33 \mathrm{e}^{-} /-2.62 \mathrm{e}^{-}$ & $3.16 \mathrm{e}^{-} /-4.95 \mathrm{e}^{-}$ \\
\hline compound & $\mathrm{CF}_{3}-\mathrm{OMe}$ & $\mathrm{CF}_{3}-\mathrm{Me}$ & $\mathrm{CF}_{3}-\mathrm{H}$ & $\mathrm{CF}_{3}-\mathrm{Cl}$ & $\mathrm{CF}_{3}-\mathrm{CF}_{3}$ \\
\hline CCDC Number & CCDC 1454146 & CCDC 1454147 & CCDC 1454158 & CCDC 1454159 & CCDC 1454160 \\
\hline Empirical Formula & $\mathrm{C}_{15} \mathrm{H}_{11} \mathrm{AuF}_{3} \mathrm{NO}$ & $\mathrm{C}_{15} \mathrm{H}_{11} \mathrm{AuF}_{3} \mathrm{~N}$ & $\mathrm{C}_{14} \mathrm{H}_{9} \mathrm{AuF}_{3} \mathrm{~N}$ & $\mathrm{C}_{14} \mathrm{H}_{8} \mathrm{AuClF}{ }_{3} \mathrm{~N}$ & $\mathrm{C}_{15} \mathrm{H}_{8} \mathrm{AuF}_{6} \mathrm{~N}$ \\
\hline Crystal Size / mm & $0.162 \times 0.147 \times 0.077$ & $0.194 \times 0.128 \times 0.059$ & $0.179 \times 0.109 \times 0.088$ & $0.354 \times 0.088 \times 0.084$ & $0.192 \times 0.140 \times 0.120$ \\
\hline$a / \AA$ & $6.6236(4)$ & $6.4001(5)$ & $7.074(1)$ & $23.060(3)$ & $7.6284(3)$ \\
\hline$b / \AA$ & $7.5290(5)$ & $7.1438(5)$ & $7.593(1)$ & $19.0224(18)$ & $14.2806(5)$ \\
\hline$c / \AA$ & $14.0866(8)$ & $14.936(1)$ & $24.140(4)$ & $9.4058(11)$ & $15.1295(5)$ \\
\hline$\alpha /^{\circ}$ & $99.775(2)$ & $95.828(2)$ & $89.996(4)$ & 90 & $112.884(1)$ \\
\hline$\beta /^{\circ}$ & $90.063(2)$ & $97.500(2)$ & $86.288(4)$ & $104.251(2)$ & $97.9770(9)$ \\
\hline$\gamma /{ }^{\circ}$ & $94.260(2)$ & $96.158(2)$ & $74.540(4)$ & 90 & $105.237(2)$ \\
\hline$V / \AA^{3}$ & $690.31(7)$ & $668.51(8)$ & $1247.0(3)$ & $3998.9(7)$ & $1410.21(8)$ \\
\hline Space Group & $P-1(\# 2)$ & $P-1(\# 2)$ & $P-1(\# 2)$ & $C 2 / c(\# 15)$ & $P-1(\# 2)$ \\
\hline$Z$ value & 2 & 2 & 4 & 12 & 4 \\
\hline$D_{\text {calc }} / \mathrm{g} \mathrm{cm}^{-3}$ & 2.286 & 2.266 & 2.371 & 2.390 & 2.417 \\
\hline Temperature / K & 123 & 123 & 123 & 123 & 123 \\
\hline $2 \theta_{\max } /^{\circ}$ & 54.9 & 54.9 & 55.0 & 55.0 & 54.9 \\
\hline$\mu\left(\mathrm{Mo} \mathrm{K}_{\alpha}\right) / \mathrm{cm}^{-1}$ & 107.240 & 110.635 & 118.587 & 112.967 & 105.331 \\
\hline \multirow[t]{3}{*}{ No. of Reflections } & Total: 6803 & Total: 6547 & Total: 12132 & Total: 19032 & Total: 13802 \\
\hline & Unique: 3146 & Unique: 3028 & Unique: 5660 & Unique: 4567 & Unique: 6379 \\
\hline & $R_{\mathrm{int}}=0.0627$ & $R_{\mathrm{int}}=0.1005$ & $R_{\mathrm{int}}=0.0755$ & $R_{\mathrm{int}}=0.1174$ & $R_{\mathrm{int}}=0.0434$ \\
\hline$R_{1}^{\mathrm{a}}$ & 0.0317 & 0.0556 & 0.0773 & 0.0854 & 0.0322 \\
\hline$w R_{2}{ }^{\mathrm{b}}$ & 0.0728 & 0.1393 & 0.1938 & 0.2493 & 0.0860 \\
\hline $\mathrm{GOF}^{c}$ & 0.964 & 1.035 & 1.122 & 1.112 & 0.817 \\
\hline Max./Mini. peak $I^{\mathrm{d}} / \AA^{3}$ & $2.52 \mathrm{e}^{-} /-1.90 \mathrm{e}^{-}$ & $4.51 \mathrm{e}^{-} /-3.08 \mathrm{e}^{-}$ & $3.50 \mathrm{e}^{-} /-4.55 \mathrm{e}^{-}$ & $2.52 \mathrm{e}^{-} /-5.22 \mathrm{e}^{-}$ & $3.01 \mathrm{e}^{-} /-1.98 \mathrm{e}^{-}$ \\
\hline
\end{tabular}

${ }^{\mathrm{a}}: I>2.00 \sigma(I) .{ }^{\mathrm{b}}:$ All reflections. ${ }^{\mathrm{c}}:$ Goodness of Fit Indicator. ${ }^{\mathrm{d}}:$ in Final Diff. Map. 


\begin{tabular}{|c|c|c|c|c|c|}
\hline compound & $\mathrm{CF}_{3}-\mathrm{CN}_{\mathrm{G}}$ & $\mathrm{CF}_{3}-\mathrm{CN}_{\mathrm{Y}}$ & $\mathrm{CN}-\mathrm{OMe}$ & CN-Me & $\mathrm{CN}-\mathrm{Cl}$ \\
\hline CCDC Number & CCDC 1454161 & CCDC 1454162 & CCDC 1454163 & CCDC 1454164 & CCDC 1454165 \\
\hline Empirical Formula & $\mathrm{C}_{15} \mathrm{H}_{8} \mathrm{AuF}_{3} \mathrm{~N}_{2}$ & $\mathrm{C}_{15} \mathrm{H}_{8} \mathrm{AuF}_{3} \mathrm{~N}_{2}$ & $\mathrm{C}_{15} \mathrm{H}_{11} \mathrm{AuN}_{2} \mathrm{O}$ & $\mathrm{C}_{15} \mathrm{H}_{11} \mathrm{AuN}_{2}$ & $\mathrm{C}_{14} \mathrm{H}_{8} \mathrm{AuClN}{ }_{2}$ \\
\hline Formula Weight & 470.20 & 470.20 & 432.23 & 416.23 & 436.65 \\
\hline Crystal System & monoclinic & orthorhombic & triclinic & triclinic & triclinic \\
\hline Crystal Size / mm & $0.181 \times 0.074 \times 0.044$ & $0.167 \times 0.147 \times 0.065$ & $0.280 \times 0.147 \times 0.064$ & $0.240 \times 0.046 \times 0.035$ & $0.085 \times 0.082 \times 0.055$ \\
\hline$a / \AA$ & $16.125(2)$ & $9.3279(4)$ & $6.6670(4)$ & $6.8738(9)$ & $6.8631(9)$ \\
\hline$b / \AA$ & $22.172(3)$ & $19.4405(8)$ & $6.9823(5)$ & $7.1009(10)$ & $7.0771(10)$ \\
\hline$c / \AA$ & $7.618(1)$ & $15.1865(8)$ & $14.9126(9)$ & $13.894(2)$ & $13.5134(17)$ \\
\hline$\alpha /^{\circ}$ & 90 & 90 & $101.885(3)$ & $77.548(4)$ & $78.171(3)$ \\
\hline$\beta /^{\circ}$ & $95.115(4)$ & 90 & $93.003(2)$ & $81.705(4)$ & $80.893(3)$ \\
\hline$\gamma /{ }^{\circ}$ & 90 & 90 & $104.876(2)$ & $72.068(3)$ & $72.624(3)$ \\
\hline$V / \AA^{3}$ & $2712.8(7)$ & $2753.9(2)$ & $652.47(7)$ & $627.83(15)$ & $609.78(14)$ \\
\hline Space Group & $P 2_{1} / c(\# 14)$ & $\operatorname{Pna2}_{1}(\# 33)$ & $P-1(\# 2)$ & $P-1(\# 2)$ & $P-1(\# 2)$ \\
\hline$Z$ value & 8 & 8 & 2 & 2 & 2 \\
\hline$D_{\text {calc }} / \mathrm{g} \mathrm{cm}^{-3}$ & 2.302 & 2.268 & 2.200 & 2.202 & 2.378 \\
\hline Temperature / K & 123 & 123 & 123 & 123 & 123 \\
\hline $2 \theta_{\max } /^{\circ}$ & 55.0 & 54.9 & 55.0 & 50.1 & 54.9 \\
\hline$\mu\left(\mathrm{Mo} \mathrm{K}_{\alpha}\right) / \mathrm{cm}^{-1}$ & 109.111 & 107.484 & 113.048 & 117.380 & 123.031 \\
\hline \multirow[t]{3}{*}{ No. of Reflections } & Total: 20535 & Total: 25160 & Total: 5159 & Total: 4754 & Total: 6001 \\
\hline & Unique: 4789 & Unique: 6271 & Unique: 2293 & Unique: 2173 & Unique: 2762 \\
\hline & $R_{\text {int }}=0.2168$ & $R_{\text {int }}=0.0556$ & $R_{\text {int }}=0.0714$ & $R_{\text {int }}=0.1091$ & $R_{\text {int }}=0.0971$ \\
\hline$R_{1}{ }^{\mathrm{a}}$ & 0.0922 & 0.0482 & 0.0544 & 0.0990 & 0.0974 \\
\hline$w R_{2}{ }^{\mathrm{b}}$ & 0.2062 & 0.1384 & 0.1394 & 0.2690 & 0.3331 \\
\hline $\mathrm{GOF}^{c}$ & 1.174 & 1.063 & 1.030 & 1.414 & 1.184 \\
\hline Max./Mini. peak $I^{\mathrm{d}} / \AA^{3}$ & $2.86 \mathrm{e}^{-} /-2.71 \mathrm{e}^{-}$ & $1.67 \mathrm{e}^{-} /-1.25 \mathrm{e}^{-}$ & $6.12 \mathrm{e}^{-} /-3.30 \mathrm{e}^{-}$ & $2.61 \mathrm{e}^{-} /-4.72 \mathrm{e}^{-}$ & $4.85 \mathrm{e}^{-} /-6.77 \mathrm{e}^{-}$ \\
\hline compound & $\mathrm{CN}-\mathrm{CF}_{3}$ & $\mathrm{CN}-\mathrm{CN}$ & & & \\
\hline CCDC Number & CCDC 1454166 & CCDC 1454167 & & & \\
\hline Empirical Formula & $\mathrm{C}_{15} \mathrm{H}_{8} \mathrm{AuF}_{3} \mathrm{~N}_{2}$ & $\mathrm{C}_{15} \mathrm{H}_{8} \mathrm{AuN}_{3}$ & & & \\
\hline Formula Weight & 470.20 & 427.21 & & & \\
\hline Crystal System & triclinic & monoclinic & & & \\
\hline Crystal Size / mm & $0.156 \times 0.066 \times 0.031$ & $0.116 \times 0.085 \times 0.055$ & & & \\
\hline$a / \AA$ & $6.941(2)$ & $13.562(7)$ & & & \\
\hline$b / \AA$ & $7.241(2)$ & $7.418(4)$ & & & \\
\hline$c / \AA$ & $14.422(3)$ & $12.868(6)$ & & & \\
\hline$\alpha /^{\circ}$ & $98.351(5)$ & 90 & & & \\
\hline$\beta /^{\circ}$ & $95.589(4)$ & $98.42(1)$ & & & \\
\hline$\gamma /{ }^{\circ}$ & $109.263(4)$ & 90 & & & \\
\hline$V / \AA^{3}$ & $668.7(2)$ & 1281(1) & & & \\
\hline Space Group & $P-1(\# 2)$ & $P 2_{1} / c(\# 14)$ & & & \\
\hline$Z$ value & 2 & 4 & & & \\
\hline$D_{\text {calc }} / \mathrm{g} \mathrm{cm}^{-3}$ & 2.335 & 2.216 & & & \\
\hline Temperature / K & 123 & 123 & & & \\
\hline $2 \theta_{\max } /^{\circ}$ & 54.9 & 54.8 & & & \\
\hline$\mu\left(\mathrm{Mo} \mathrm{K}_{\alpha}\right) / \mathrm{cm}^{-1}$ & 110.658 & 115.157 & & & \\
\hline \multirow[t]{3}{*}{ No. of Reflections } & Total: 6593 & Total:11899 & & & \\
\hline & Unique: 3031 & Unique: 2921 & & & \\
\hline & $R_{\mathrm{int}}=0.1475$ & $R_{\text {int }}=0.1378$ & & & \\
\hline$R_{1}{ }^{\mathrm{a}}$ & 0.0796 & 0.0760 & & & \\
\hline$w R_{2}^{\mathrm{b}}$ & 0.2020 & 0.2336 & & & \\
\hline $\mathrm{GOF}^{c}$ & 0.978 & 1.132 & & & \\
\hline Max./Mini. peak $I^{\mathrm{d}} / \AA^{3}$ & $1.59 \mathrm{e}^{-} /-2.38 \mathrm{e}^{-}$ & $2.77 \mathrm{e}^{-} /-4.16 \mathrm{e}^{-}$ & & & \\
\hline
\end{tabular}

${ }^{\mathrm{a}}: I>2.00 \sigma(I) .{ }^{\mathrm{b}}:$ All reflections. ${ }^{\mathrm{c}}:$ Goodness of Fit Indicator. ${ }^{\mathrm{d}}:$ in Final Diff. Map. 


\section{Excitation and Emission Spectra of As-Prepared Powders and Single Crystals of $\mathbf{R}^{1}-\mathbf{R}^{2}$}

Figures S8-S12 show excitation (dotted lines) and emission spectra (solid lines) of as-prepared powders (colored lines, denoted as "P") and the single crystals (black lines, denoted as "C") of $\mathbf{R}^{1}-\mathbf{R}^{\mathbf{2}}$.

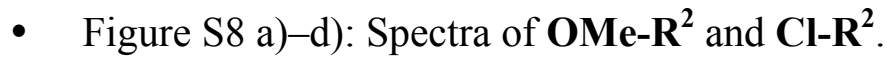

- Figure S9 a)-f): Spectra of Me-R ${ }^{2}$.

- Figure $\mathrm{S}(0 \mathrm{a})-\mathrm{f})$ : Spectra of $\mathbf{H}-\mathbf{R}^{2}$.

- Figure $\mathrm{S}(1 \mathrm{a})-\mathrm{f}$ ): Spectra of $\mathbf{C F}_{3}-\mathbf{R}^{2}$.

- Figure S12 a)-f): Spectra of $\mathbf{C N}-\mathbf{R}^{2}$.

Because we can not obtain the single crystal of $\mathbf{C N}-\mathbf{H}$, the reprecipitated powder of $\mathbf{C N}-\mathbf{H}$ was used for recording its spectral data of unground phase (black line, denoted as "Pr" in Figure S12c). For the spectra of the as-prepared forms, colors of the lines are corresponding to the emission colors of each sample. The monitored emission wavelength and excitation wavelength are all summarized in Table S4. 
a)

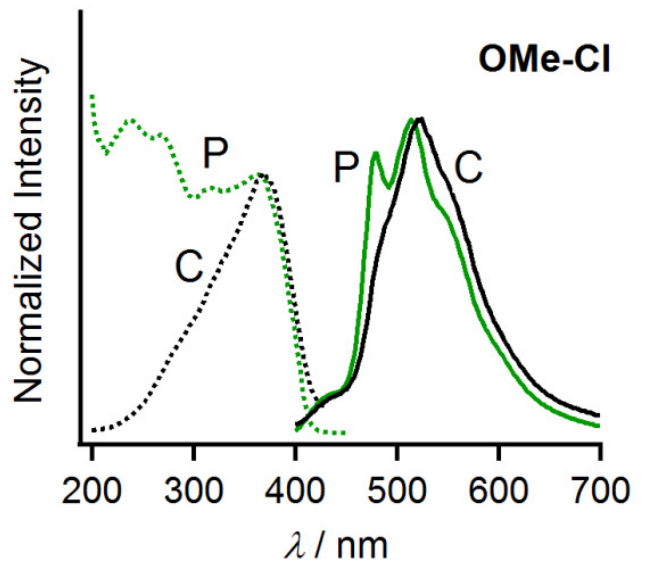

c)

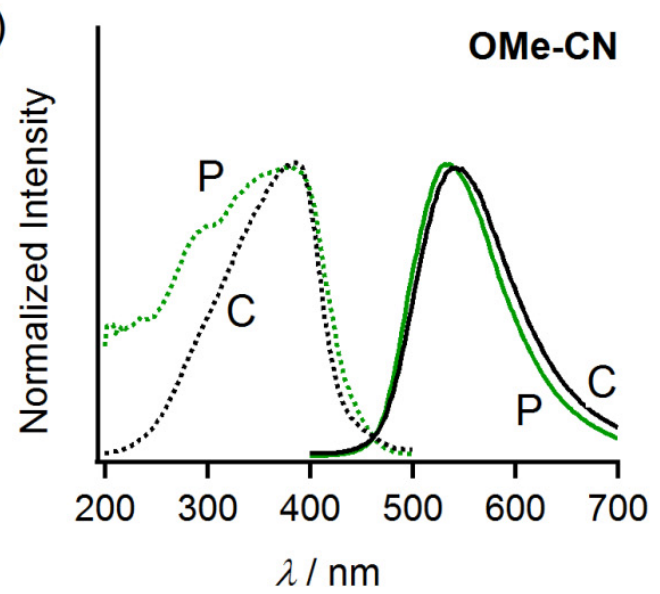

b)

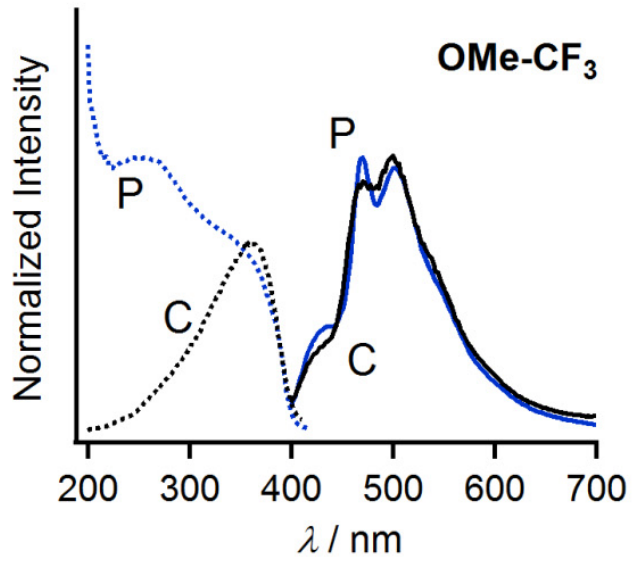

d)

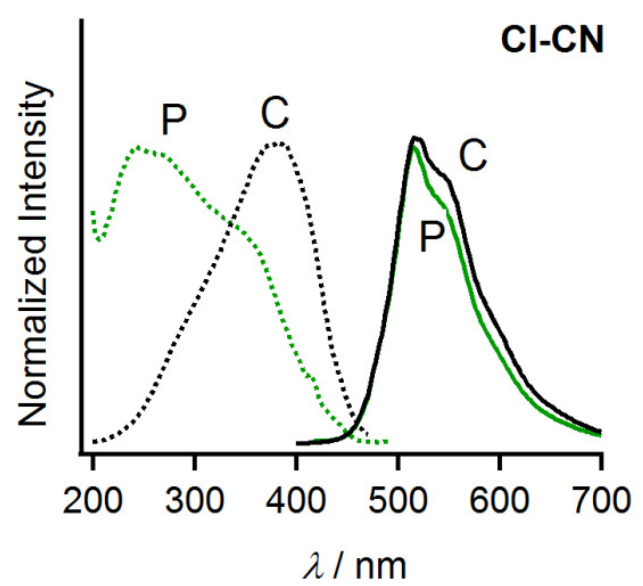

Figure S8. Excitation (dotted lines) and emission spectra (solid lines) of the as-prepared powders (colored lines, denoted as "P") and the single crystals (denoted as "C") of $\mathbf{O M e}-\mathbf{R}^{2}$ and $\mathbf{C l}-\mathbf{R}^{2}$ : a) $\mathbf{O M e}-\mathbf{C l}$, b) $\mathbf{O M e}_{-} \mathbf{C F}_{3}$, c) $\mathbf{O M e}-\mathbf{C N}$, and d) $\mathbf{C l}-\mathbf{C N}$. The measurement conditions are summarized in Table S4. 
a)

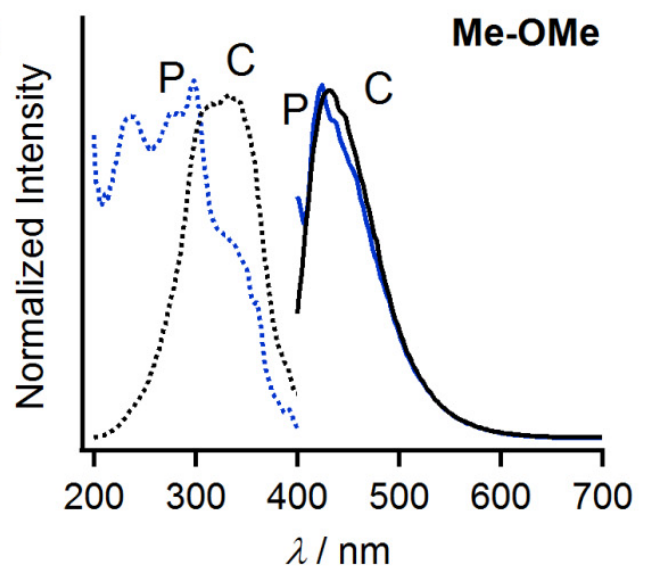

c)

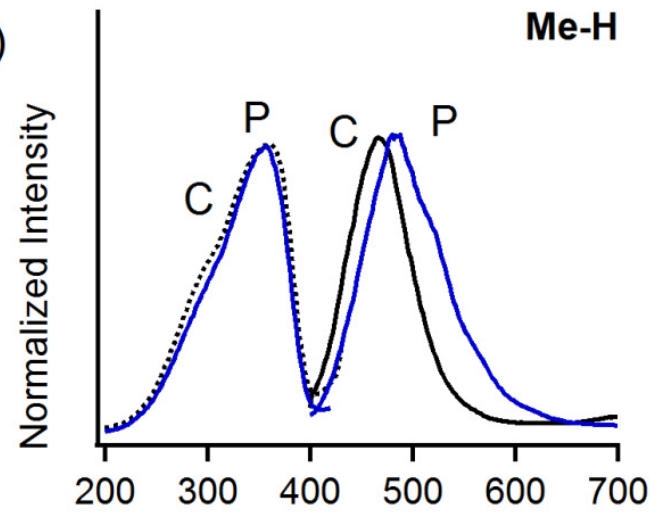

$\lambda / \mathrm{nm}$

e)

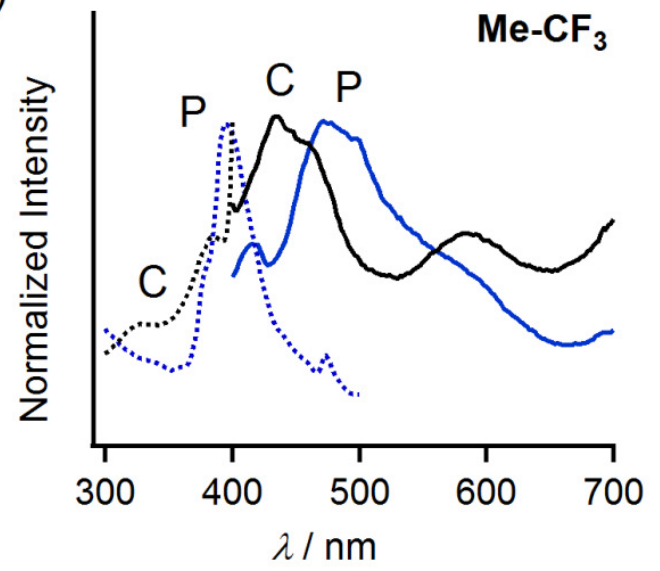

b)

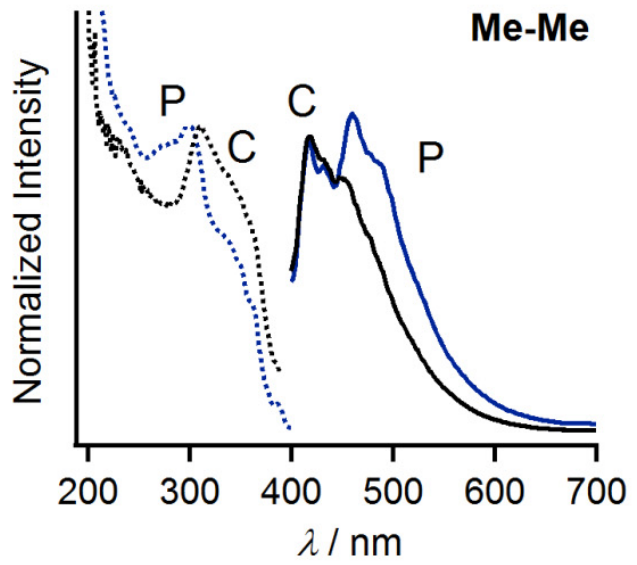

d)

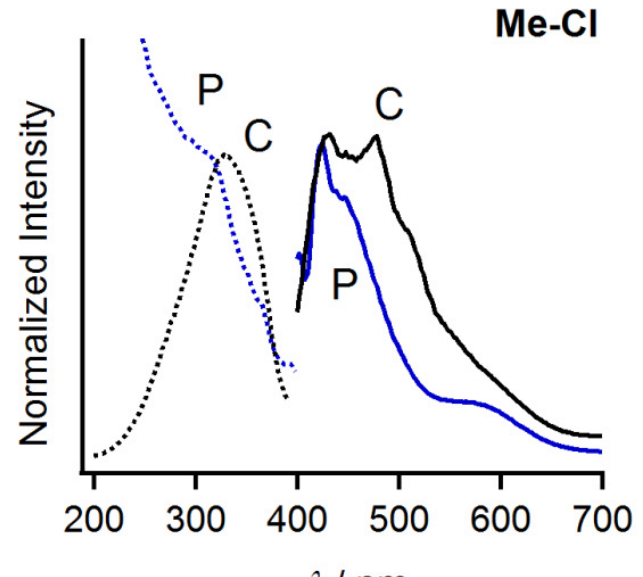

f)

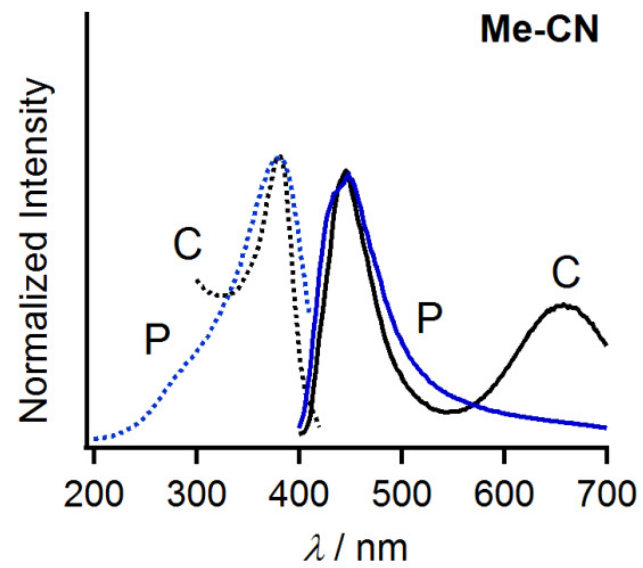

Figure S9. Excitation (dotted lines) and emission spectra (solid lines) of the as-prepared powders (colored lines, denoted as "P") and the single crystals (denoted as "C") of Me-R': a) Me-OMe, b) $\mathrm{Me}-\mathrm{Me}$, c) $\mathrm{Me}-\mathrm{H}$, d) $\mathrm{Me}-\mathrm{Cl}$, e) $\mathbf{M e -} \mathrm{CF}_{3}$, and f) $\mathrm{Me}-\mathrm{CN}$. The measurement conditions are summarized in Table S4.

Note: Two emission spectra of $\mathbf{M e}-\mathbf{C F}_{3}$ (black and blue solid lines, Figure S9e) look slightly different, owing to the weak emission intensity. However, they both show blue emission (Table S2). 
a)

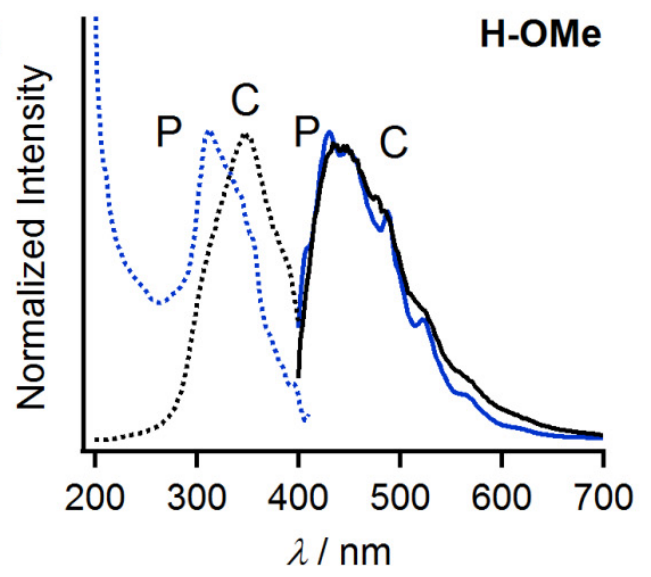

c)

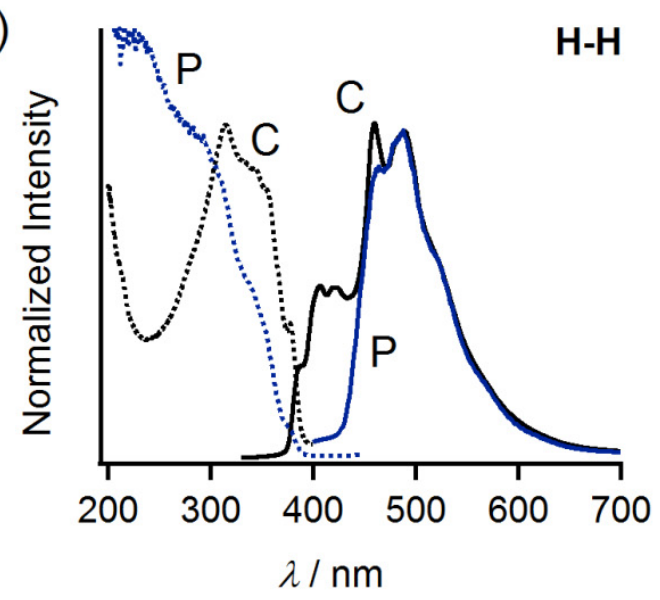

e)

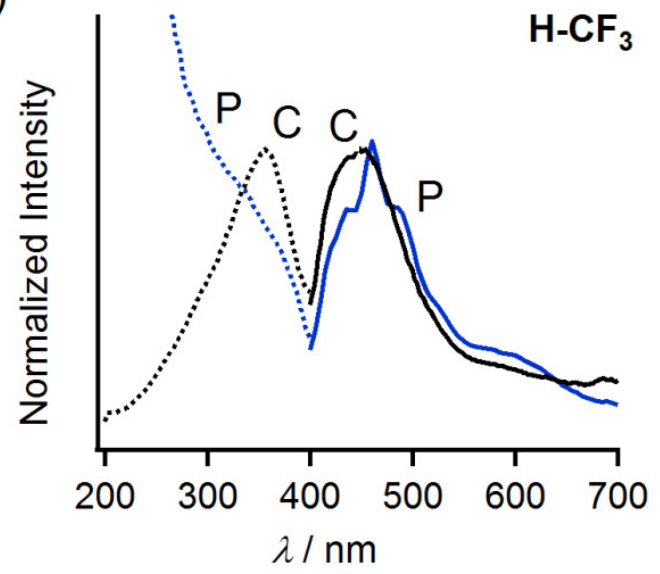

b)

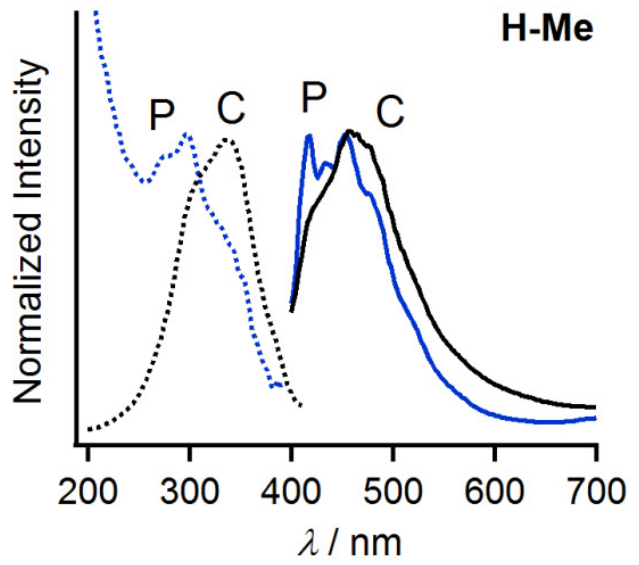

d)

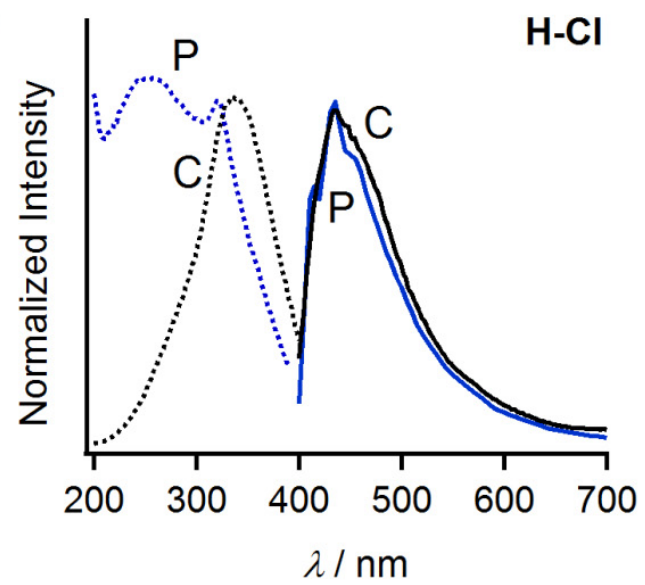

f)

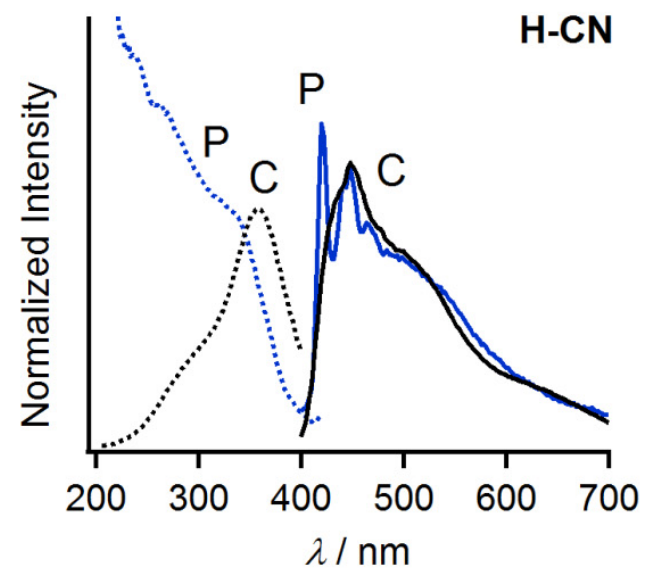

Figure S10. Excitation (dotted lines) and emission spectra (solid lines) of the as-prepared powders (colored lines, denoted as "P") and the single crystals (denoted as "C") of $\mathbf{H}-\mathbf{R}^{\mathbf{2}}$ : a) H-OMe, b) $\mathbf{H}-\mathrm{Me}$, c) $\mathbf{H}-\mathbf{H},{ }^{\mathrm{S} 7}$ d) $\mathbf{H}-\mathbf{C l}$, e) $\mathbf{H}-\mathbf{C F}_{3}$, and f) $\mathbf{H}-\mathbf{C N}$. The measurement conditions are summarized in Table S4. 
a)

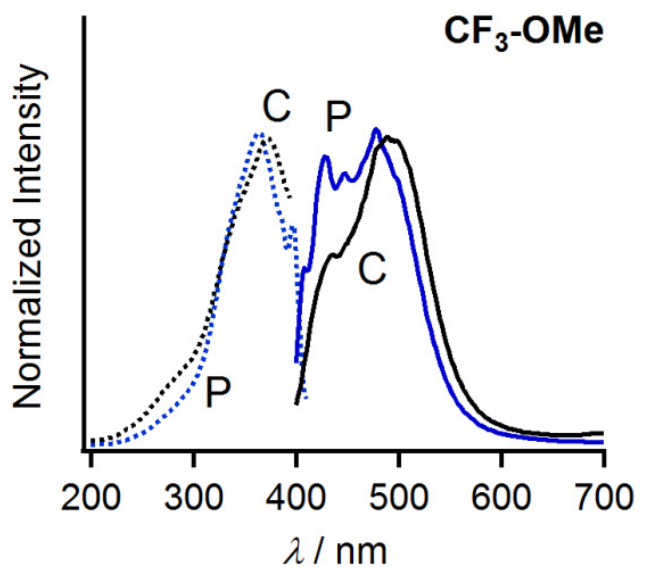

c)

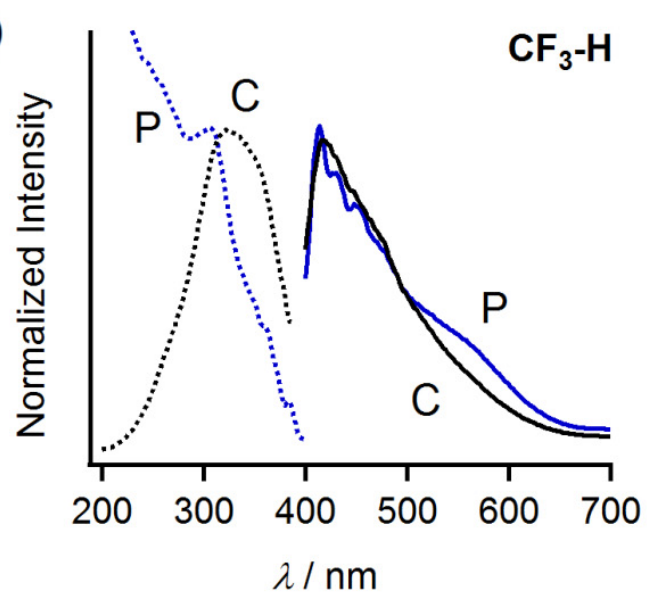

e)

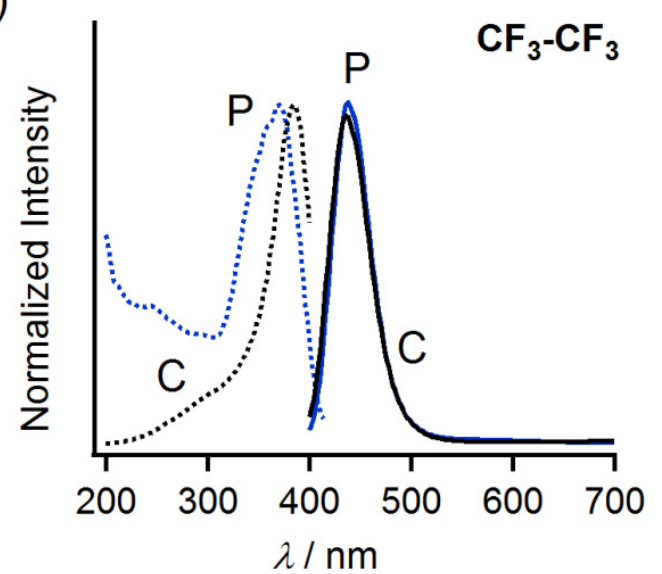

b)

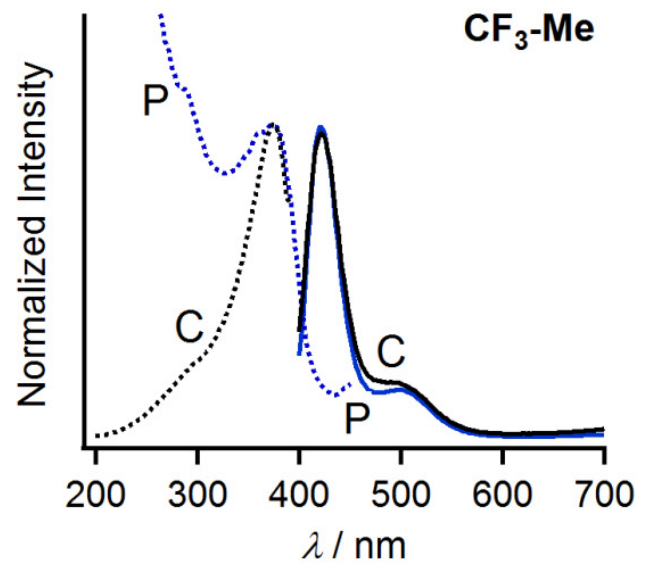

d)

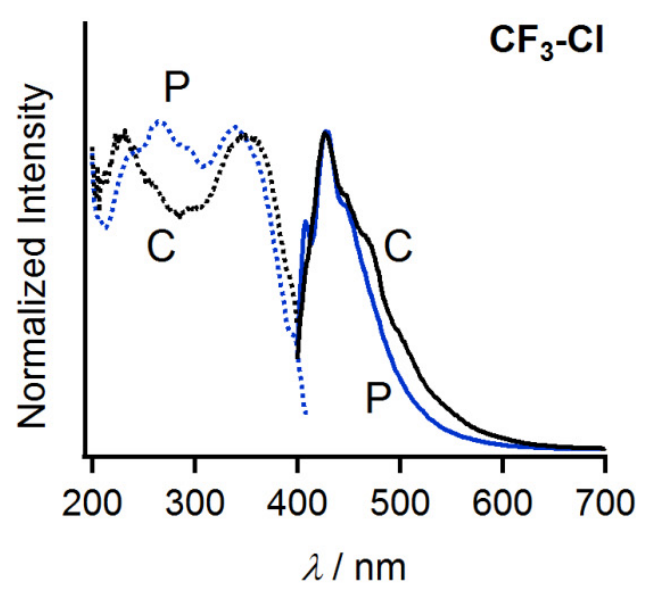

f)

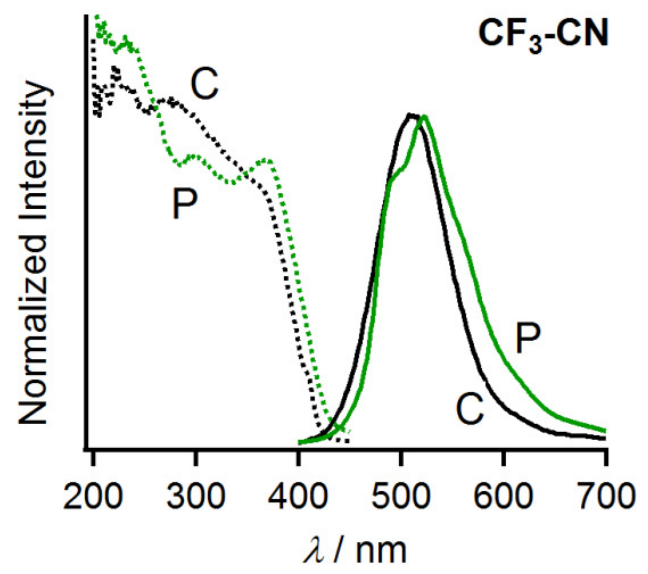

Figure S11. Excitation (dotted lines) and emission spectra (solid lines) of the as-prepared powders (colored lines, denoted as "P") and the single crystals (denoted as "C") of $\mathbf{C F}_{\mathbf{3}}-\mathbf{R}^{2}$ : a) $\mathbf{C F}_{\mathbf{3}} \mathbf{- O M e}, \mathrm{b}$ ) $\mathbf{C F}_{3}-\mathrm{Me}$, c) $\mathbf{C F}_{3}-\mathbf{H}$, d) $\mathbf{C F}_{3}-\mathbf{C l}$, e) $\mathbf{C F}_{3}-\mathbf{C F}_{3}$, and f) $\mathbf{C F}_{3}-\mathbf{C N}$. The measurement conditions are summarized in Table S4. 
a)

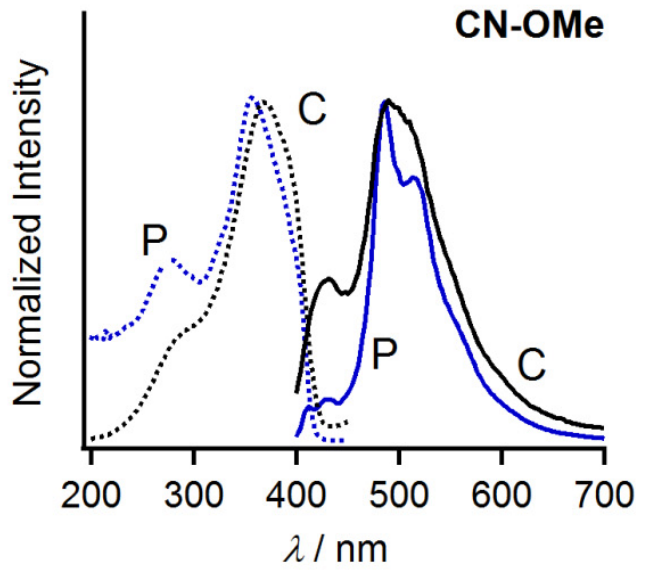

c)

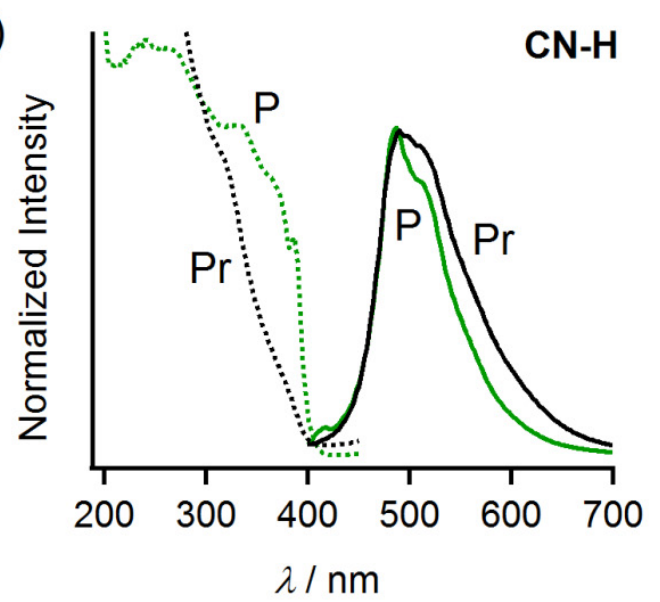

e)

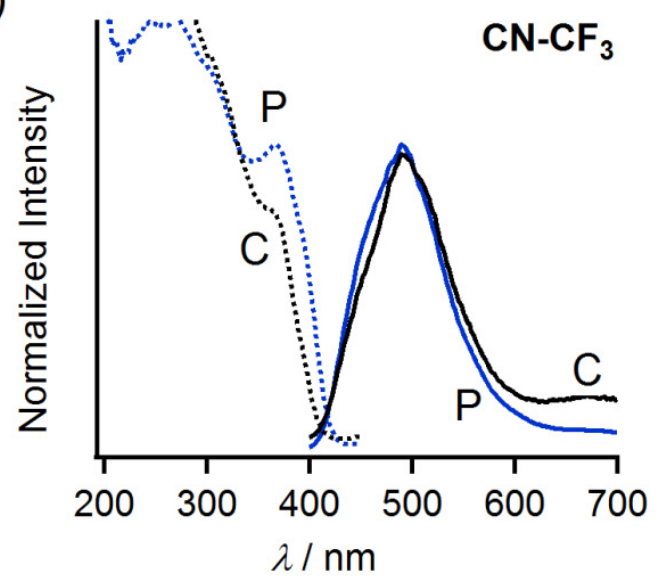

b)

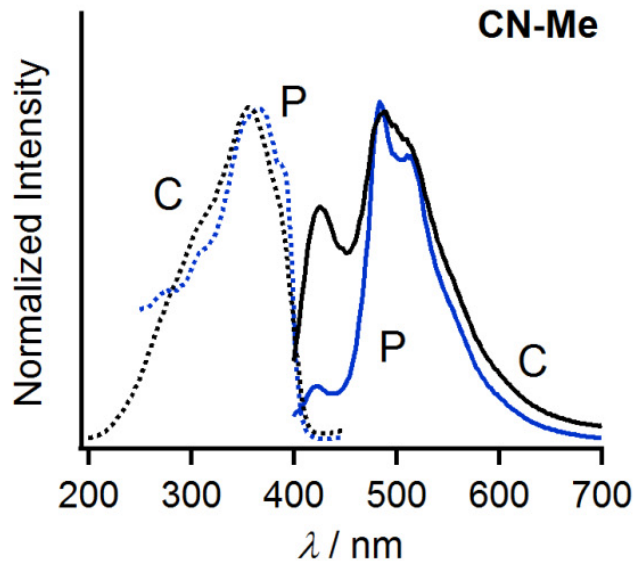

d)

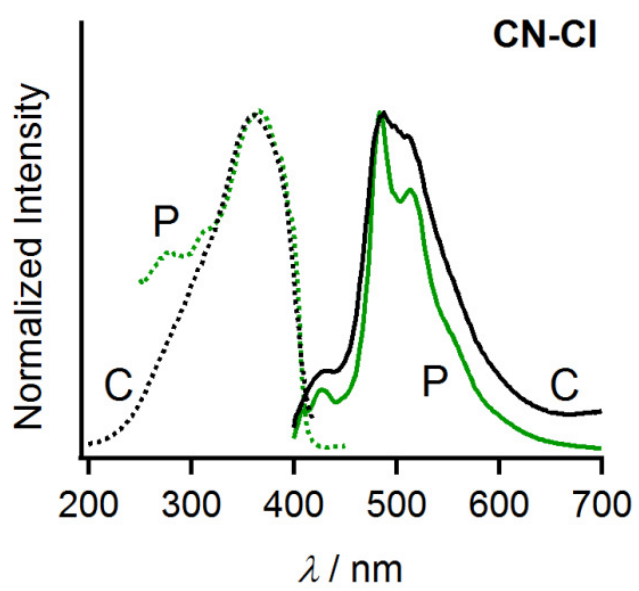

f)

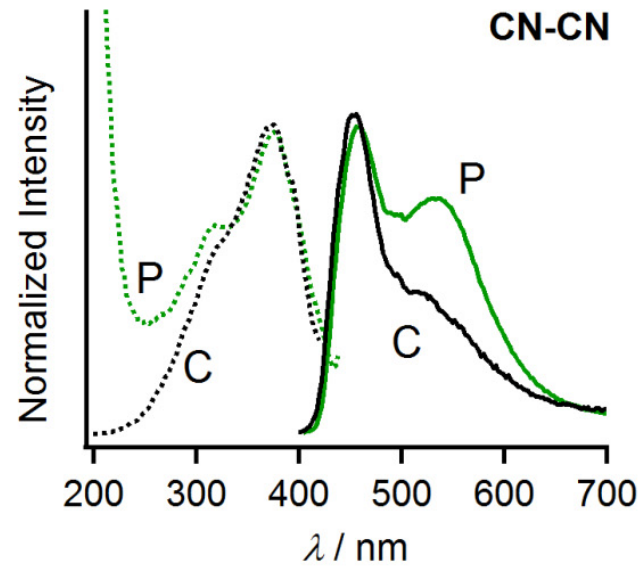

Figure S12. Excitation (dotted lines) and emission spectra (solid lines) of the as-prepared powders (colored lines, denoted as "P") and the reprecipitated powder (denoted as "Pr" only for $\mathbf{C N}-\mathbf{H}$ ) or single crystals (denoted as "C", for rather than $\mathbf{C N}-\mathbf{H}$ ) of $\mathbf{C N}-\mathbf{R}^{2}$ : a) $\mathbf{C N}-\mathbf{O M e}$, b) $\mathbf{C N}-\mathbf{M e}, \mathrm{c}$ ) $\mathbf{C N}-\mathbf{H}$, d) $\mathbf{C N}-\mathbf{C l}$, e) $\mathbf{C N}-\mathbf{C F}_{3}$, and f) $\mathbf{C N}-\mathbf{C N}$. The measurement conditions are summarized in Table S4. 
Table S4. Summary of the measurement conditions for the excitation and emission spectra shown in Fig S8-S12.

\begin{tabular}{|c|c|c|c|c|c|}
\hline Figure & Complexes & $\begin{array}{l}\text { Monitored } \\
\text { emission } \\
\text { wavelength of the } \\
\text { as-prepared phases } \\
/ \mathrm{nm} \\
\end{array}$ & $\begin{array}{l}\text { Monitored } \\
\text { emission } \\
\text { wavelength of the } \\
\text { single crystals / } \\
\text { nm }\end{array}$ & $\begin{array}{l}\text { Excitation } \\
\text { wavelength of the } \\
\text { as-prepared phases } \\
\text { / nm }\end{array}$ & $\begin{array}{l}\text { Excitation } \\
\text { wavelength of the } \\
\text { single crystals / } \\
\mathrm{nm}\end{array}$ \\
\hline Figure S8 a) & OMe-Cl & 510 & 485 & 365 & 365 \\
\hline Figure $\mathrm{S} 8 \mathrm{~b}$ ) & $\mathrm{OMe}_{-} \mathrm{CF}_{3}$ & 470 & 467 & 365 & 365 \\
\hline Figure S8 c) & OMe-CN & 531 & 540 & 365 & 365 \\
\hline Figure S8 d) & Cl-CN & 515 & 516 & 365 & 365 \\
\hline Figure S9 a) & Мe-OMe & 420 & 431 & 365 & 365 \\
\hline Figure S9 b) & Мe-Me & 460 & 417 & 365 & 365 \\
\hline Figure S9 c) & Мe-H & 482 & 465 & 365 & 365 \\
\hline Figure S9 d) & Me-Cl & 566 & 430 & 365 & 365 \\
\hline Figure S9 e) & $\mathrm{Me}-\mathrm{CF}_{3}$ & 590 & 433 & 365 & 365 \\
\hline Figure S9 f) & $\mathrm{Me}-\mathrm{CN}$ & 450 & 447 & 365 & 365 \\
\hline Figure S10 a) & H-OMe & 429 & 436 & 365 & 365 \\
\hline Figure S10 b) & H-Me & 417 & 456 & 365 & 365 \\
\hline Figure S10 c) & $\mathbf{H}-\mathbf{H}^{\mathrm{S} 7}$ & 488 & 488 & 365 & 365 \\
\hline Figure S10 d) & $\mathrm{H}-\mathrm{Cl}$ & 412 & 434 & 365 & 365 \\
\hline Figure S10 e) & $\mathrm{H}-\mathrm{CF}_{3}$ & 468 & 452 & 365 & 365 \\
\hline Figure S10 f) & $\mathrm{H}-\mathrm{CN}$ & 448 & 448 & 241 & 365 \\
\hline Figure S11 a) & $\mathrm{CF}_{3}-\mathrm{OMe}$ & 429 & 433 & 365 & 365 \\
\hline Figure $\mathrm{S} 11 \mathrm{~b}$ ) & $\mathrm{CF}_{3}-\mathrm{Me}$ & 420 & 421 & 365 & 365 \\
\hline Figure S11 c) & $\mathbf{C F}_{3}-\mathrm{H}$ & 448 & 418 & 365 & 365 \\
\hline Figure S11 d) & $\mathrm{CF}_{3}-\mathrm{Cl}$ & 425 & 428 & 365 & 365 \\
\hline Figure S11 e) & $\mathrm{CF}_{3}-\mathrm{CF}_{3}$ & 435 & 437 & 365 & 365 \\
\hline Figure S11 f) & $\mathrm{CF}_{3}-\mathrm{CN}$ & 522 & 510 & 365 & 370 \\
\hline Figure S12 a) & CN-OMe & 485 & 489 & 360 & 365 \\
\hline Figure S12 b) & $\mathrm{CN}-\mathrm{Me}$ & 448 & 488 & 365 & 365 \\
\hline Figure S12 c) & $\mathrm{CN}-\mathrm{H}$ & 490 & 490 & 365 & 365 \\
\hline Figure S12 d) & $\mathrm{CN}-\mathrm{Cl}$ & 484 & 487 & 365 & 365 \\
\hline Figure S12 e) & $\mathrm{CN}-\mathrm{CF}_{3}$ & 490 & 436 & 365 & 365 \\
\hline Figure S12 f) & $\mathrm{CN}-\mathrm{CN}$ & 456 & 453 & 372 & 365 \\
\hline
\end{tabular}




\section{Comparisons of Simulated Powder and PXRD Patterns of $\mathbf{R}^{1}-\mathbf{R}^{2}$}

Figures S13-S19 show simulated powder patterns derived from the single crystals $\mathbf{R}^{1}-\mathbf{R}^{2}$ (upper patterns) and PXRD patterns (lower patterns) of $\mathbf{R}^{\mathbf{1}}-\mathbf{R}^{\mathbf{2}}$ ground. When mechanochromism are based on crystal-to-crystal, crystal-to-(partial) amorphous, and crystal-to-amorphous phase transitions, we denote "C-to-C", "C-to-pA", and "C-to-A", respectively.

- $\quad$ Figure S13 a)-d):

Simulated and PXRD patterns of a) OMe-Cl, b) OMe-CF $\mathbf{O F}_{3}$ c) OMe-CN, and d) Me-OMe.

- $\quad$ Figure S14 a)-d):

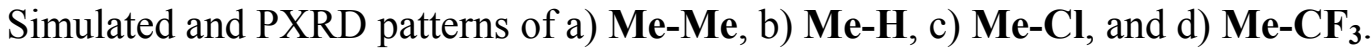

- $\quad$ Figure S15 a)-d):

Simulated and PXRD patterns of a) Me-CN, b) H-OMe, c) H-Me, and d) H-H.

- $\quad$ Figure S16 a)-d):

Simulated and PXRD patterns of a) $\mathbf{H}-\mathbf{C l}$, b) $\mathbf{H}-\mathbf{C F}_{\mathbf{3}}, \mathrm{c}$ ) $\mathbf{H}-\mathbf{C N}$, and d) $\mathbf{C l - C N}$.

- $\quad$ Figure S17 a)-d):

Simulated and PXRD patterns of a) $\mathbf{C F}_{3}-\mathbf{O M e}$, b) $\mathbf{C F}_{3}-\mathbf{M e}$, c) $\mathbf{C F}_{3}-\mathbf{H}$, and d) $\mathbf{C F}_{3}-\mathbf{C l}$.

- $\quad$ Figure S18 a)-d):

Simulated and PXRD patterns of a) $\mathbf{C F}_{3}-\mathbf{C F}_{3}$, b) $\mathbf{C F}_{3}-\mathbf{C N}$, c) $\mathbf{C N}-\mathrm{OMe}$, and d) $\mathbf{C N}-\mathbf{M e}$.

- $\quad$ Figure S19 a)-d):

Simulated and PXRD patterns of a) $\mathbf{C N}-\mathbf{H}$ and b) $\mathbf{C N}-\mathbf{C l}$, c) $\mathbf{C N}-\mathbf{C F}_{3}$, and d) $\mathbf{C N}-\mathbf{C N}$. 

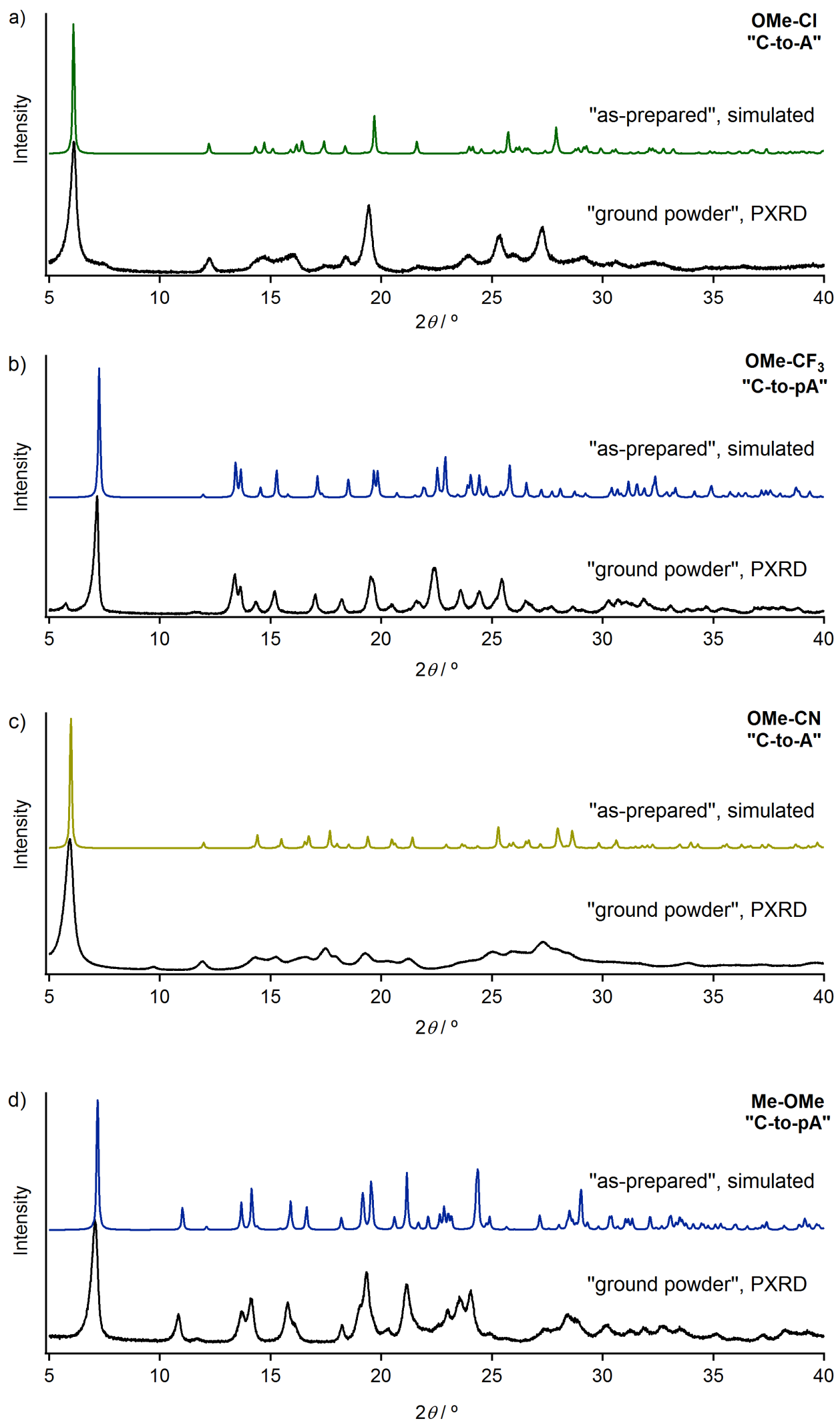

Figure S13. Simulated powder patterns (upper patterns) and PXRD patterns of the ground powders (lower patterns) of a) $\mathbf{O M e}-\mathrm{Cl}$, b) $\mathrm{OMe}_{\mathbf{C}} \mathrm{CF}_{3}$, c) $\mathbf{O M e}-\mathrm{CN}$, and d) Me-OMe. 
a)
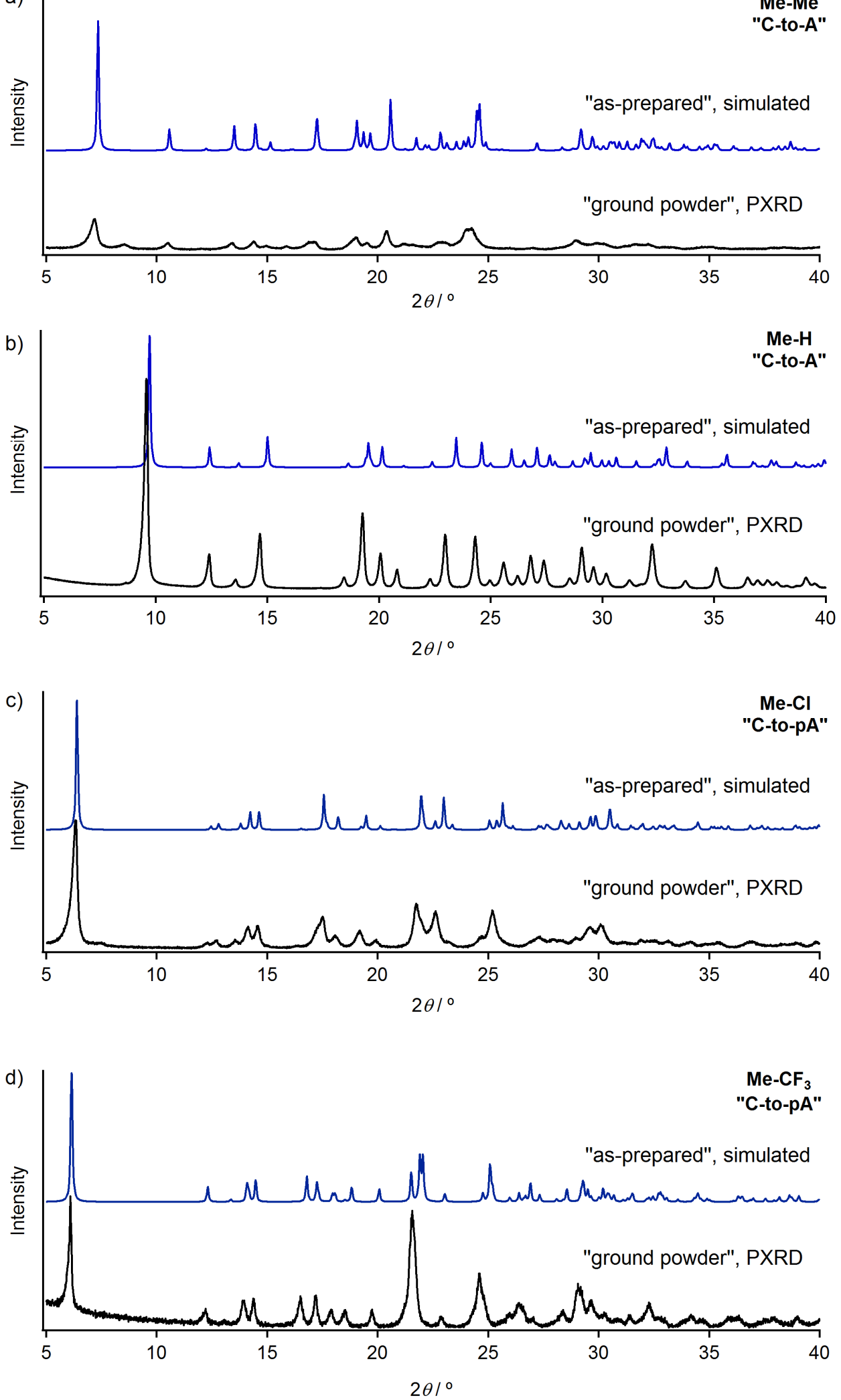

Figure S14. Simulated powder patterns (upper patterns) and PXRD patterns of the ground powders

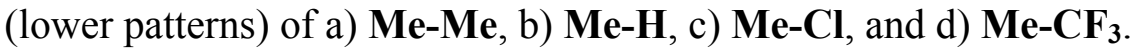



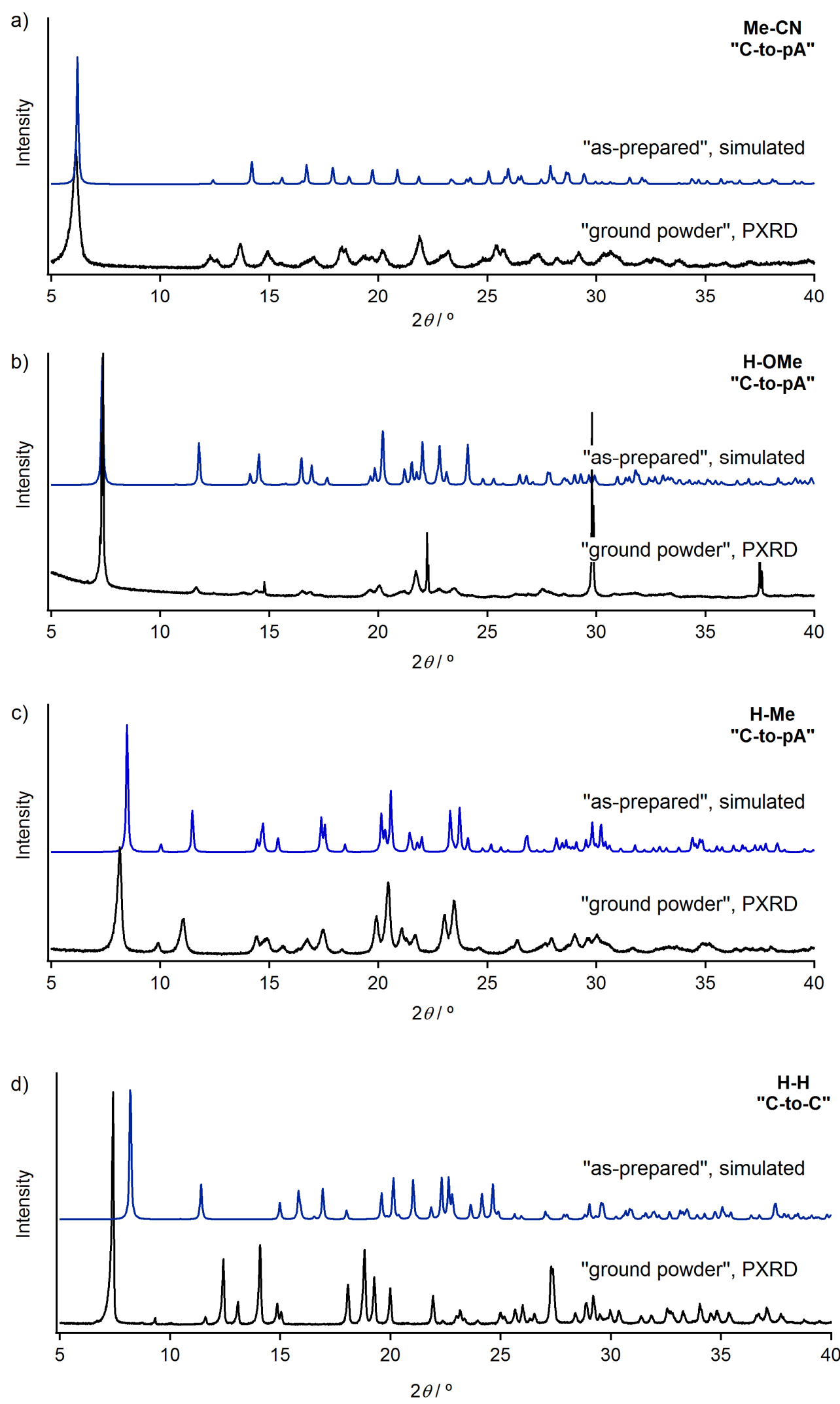

Figure S15. Simulated powder patterns (upper patterns) and PXRD patterns of the ground powders (lower patterns) of a) Me-CN, b) H-OMe, c) H-Me, and d) H-H. 

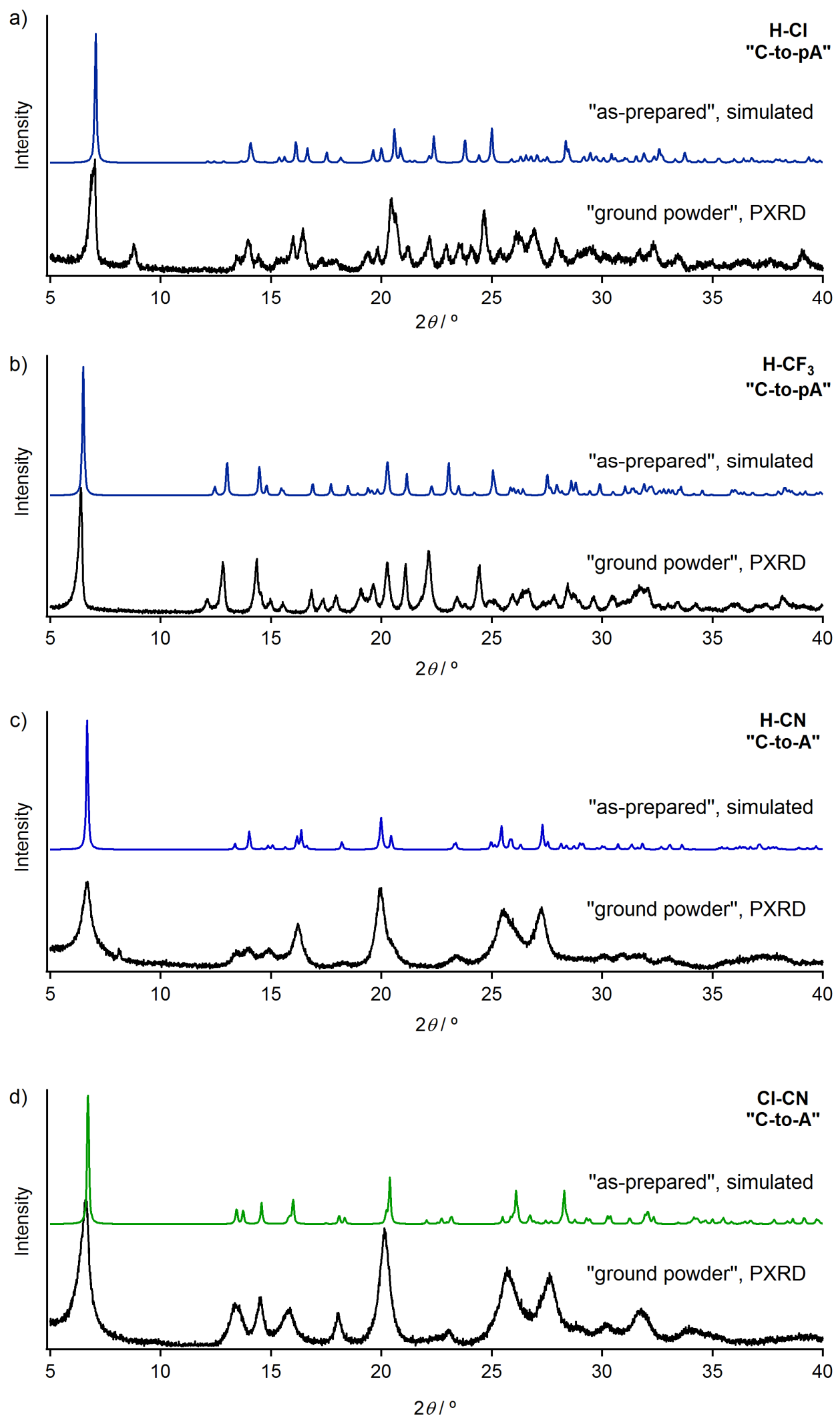

Figure S16. Simulated powder patterns (upper patterns) and PXRD patterns of the ground powders (lower patterns) of a) $\mathbf{H}-\mathbf{C l}$, b) $\mathbf{H}-\mathbf{C F}_{3}$, c) $\mathbf{H}-\mathbf{C N}$, and d) $\mathbf{C l}-\mathbf{C N}$. 

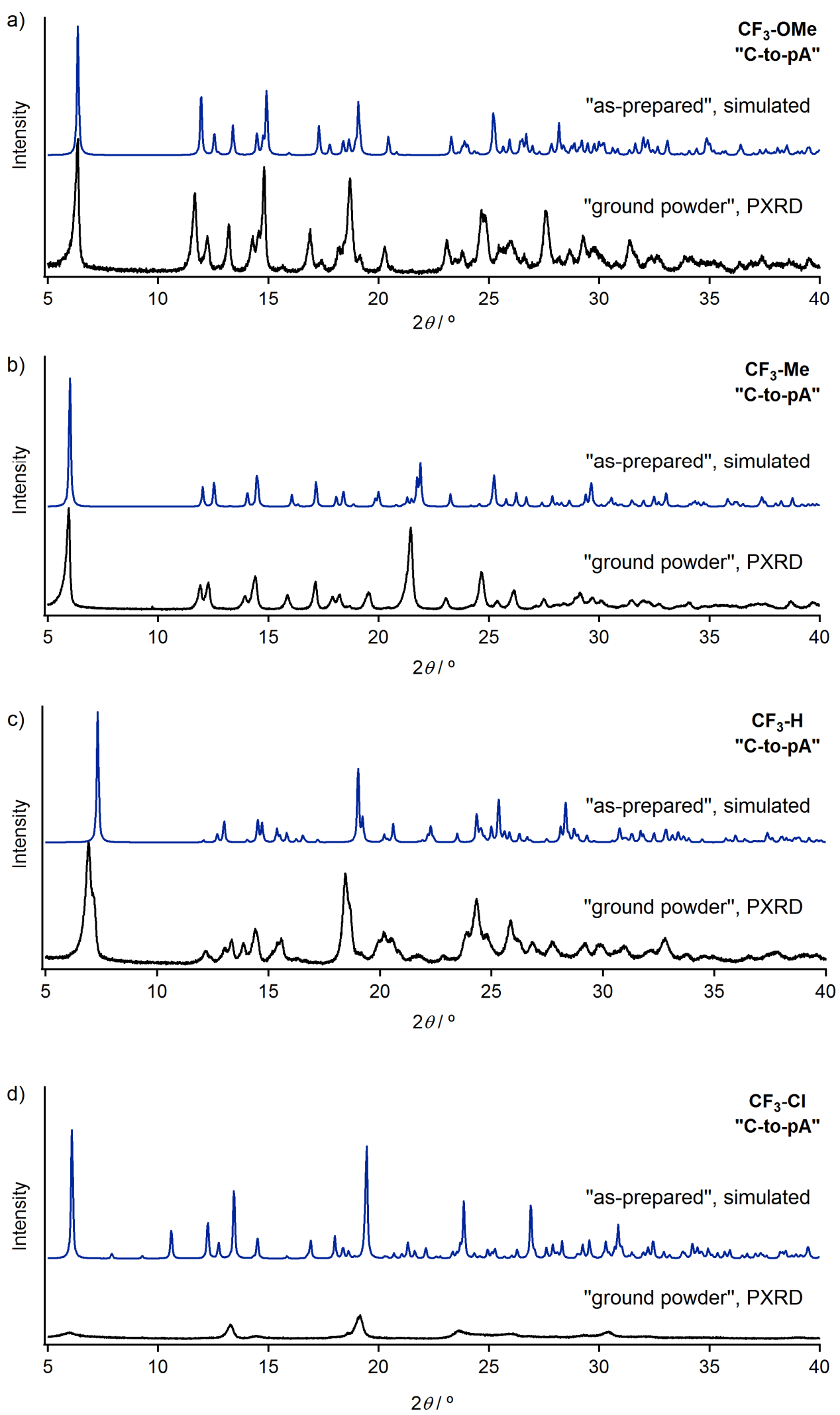

Figure S17. Simulated powder patterns (upper patterns) and PXRD patterns of the ground powders (lower patterns) of a) $\mathbf{C F}_{3}-\mathbf{O M e}$, b) $\mathbf{C F}_{3}-\mathbf{M e}$, c) $\mathbf{C F}_{3}-\mathbf{H}$, and d) $\mathbf{C F}_{3}-\mathbf{C l}$. 

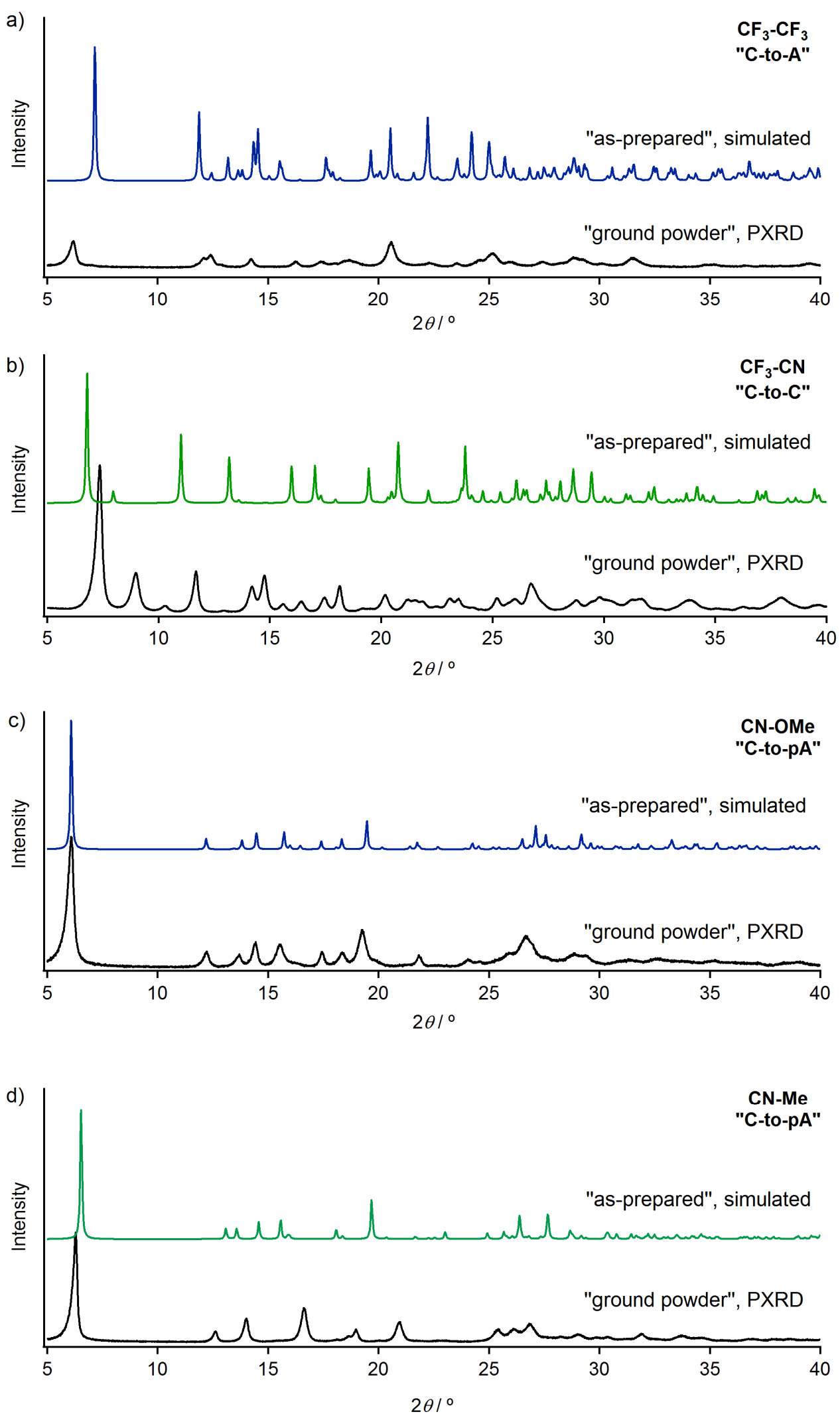

Figure S18. Simulated powder patterns (upper patterns) and PXRD patterns of the ground powders (lower patterns) of a) $\mathbf{C F}_{3}-\mathbf{C F}_{3}$, b) $\mathbf{C F}_{3}-\mathbf{C N}$, c) $\mathbf{C N}-\mathbf{O M e}$, and d) $\mathbf{C N}-\mathrm{Me}$. 

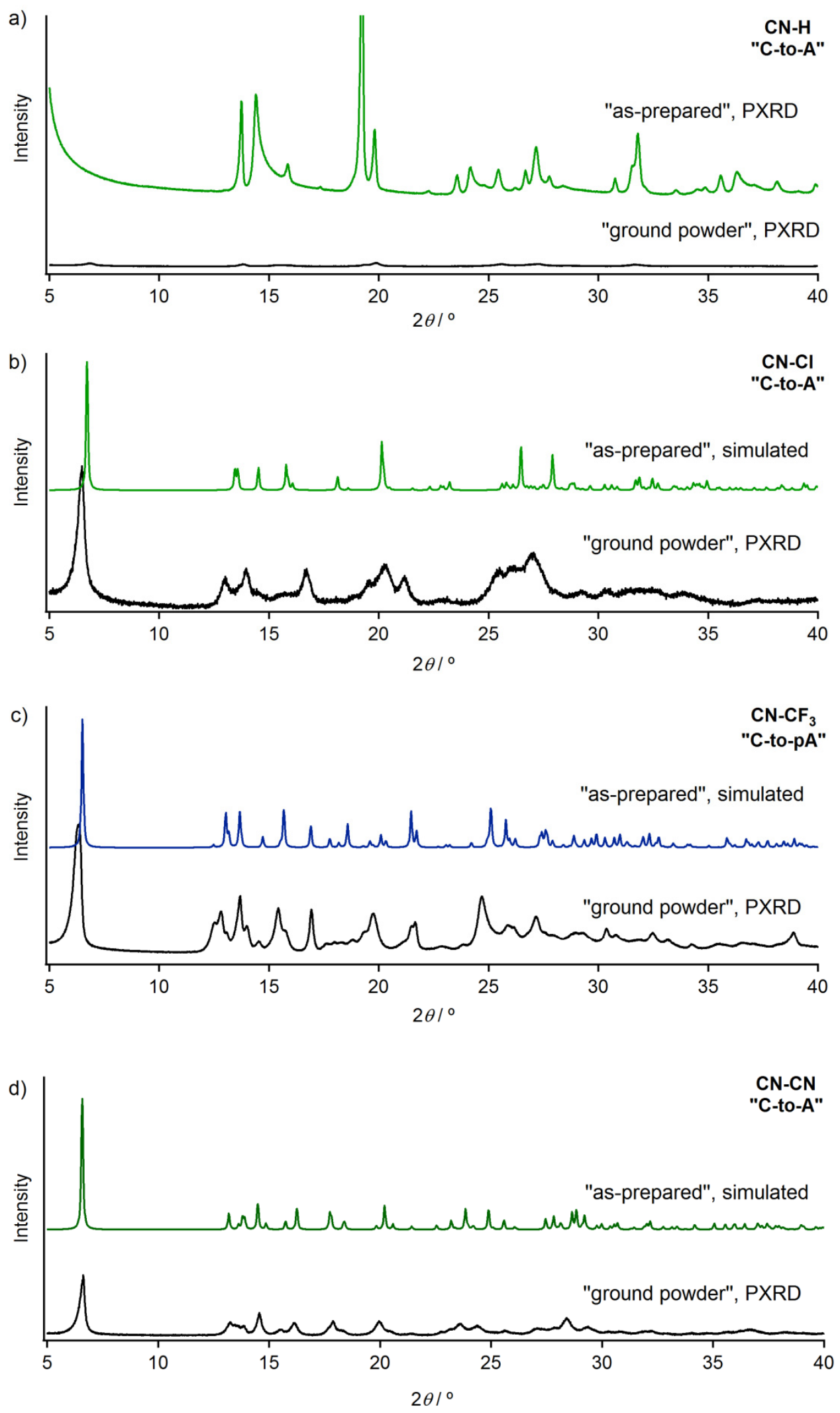

Figure S19. Simulated powder patterns (upper patterns) and PXRD patterns of the ground powders (lower patterns) of a) $\mathbf{C N}-\mathbf{H}$ and b) $\mathbf{C N}-\mathbf{C l}$, c) $\mathbf{C N}-\mathbf{C F}_{3}$, and d) $\mathbf{C N}-\mathbf{C N}$. Diffraction pattern of unground phase of $\mathbf{C N}-\mathbf{H}$ was obtained from the PXRD measurements of the reprecipitated powder. 


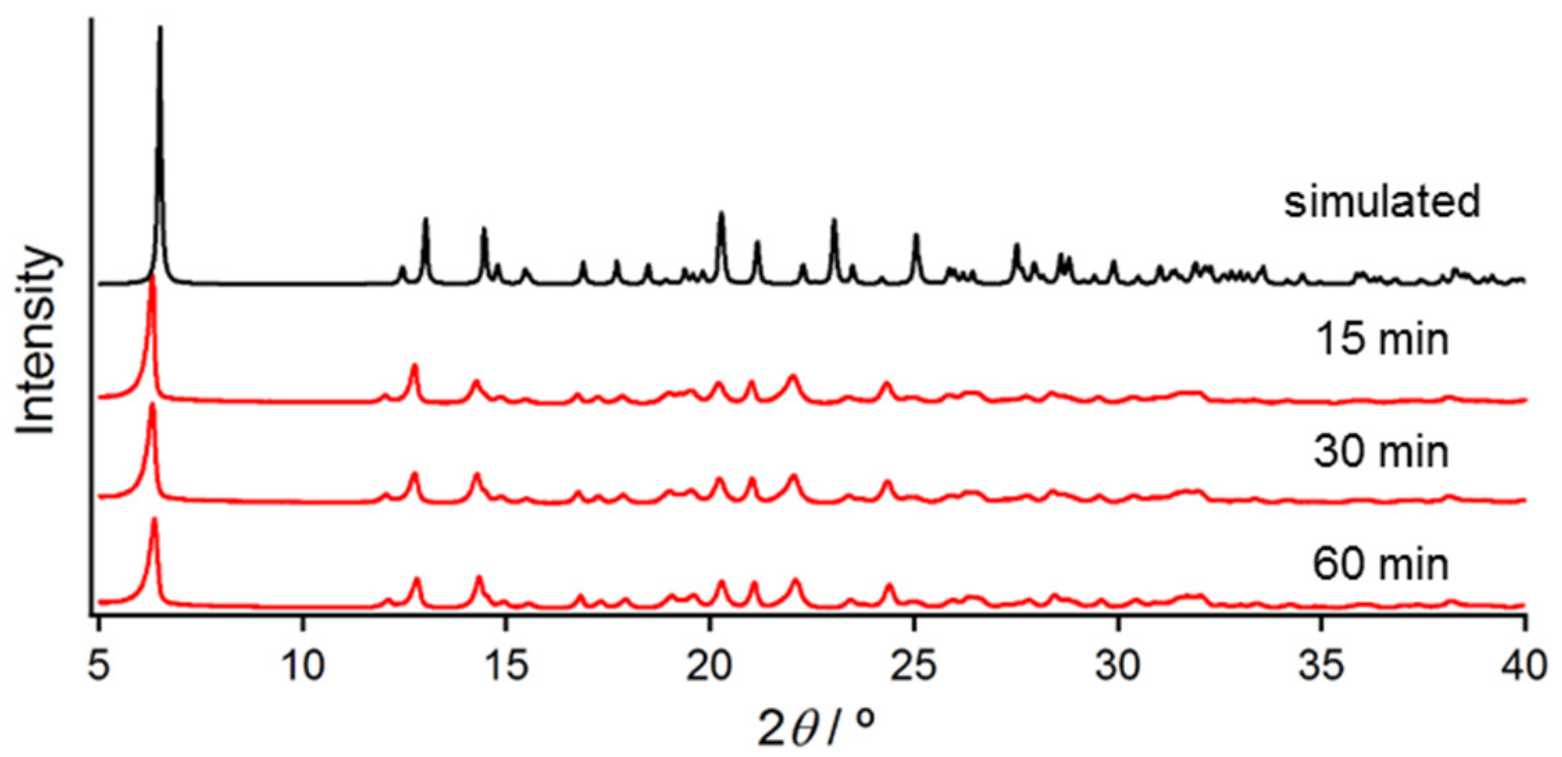

Figure S20. PXRD patterns of $\mathbf{H}-\mathbf{C F}_{3}$. Black line shows simulated powder pattern derived from the single crystal structure which is corresponding to unground phase. Red lines were PXRD patterns of ground powders of $\mathbf{H}-\mathbf{C F}_{\mathbf{3}}$ which prepared by different ball-milling time (ball-milling times were denoted). 


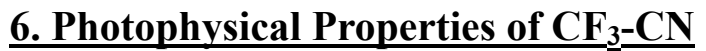

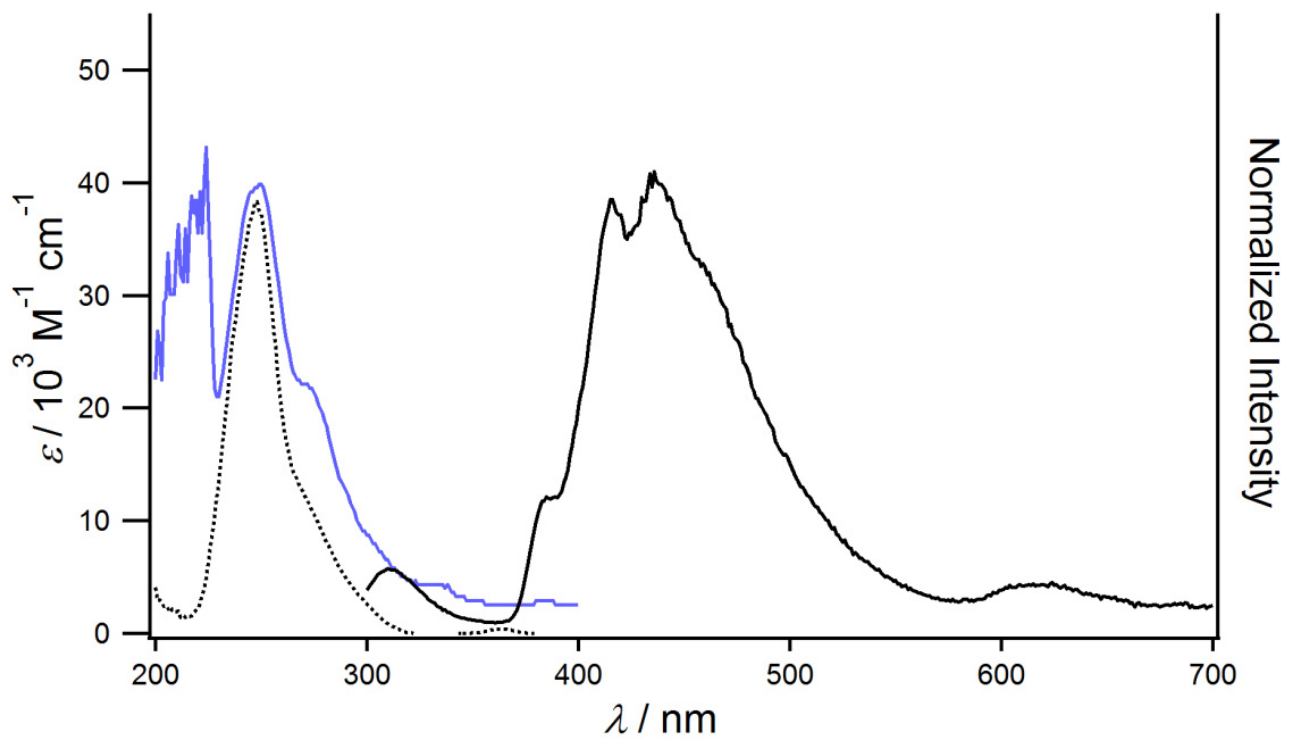

Figure S21. UV/vis absorption (blue solid line), excitation (black dotted line, $\lambda_{e m}=413 \mathrm{~nm}$ ), and emission (black solid line, $\lambda_{e x}=250 \mathrm{~nm}$ ) spectra of $\mathbf{C F}_{\mathbf{3}} \mathbf{-} \mathbf{C N}$ in $\mathrm{CH}_{2} \mathrm{Cl}_{2}\left(c=2.8 \times 10^{-6} \mathrm{M}\right.$ ) at room temperature.

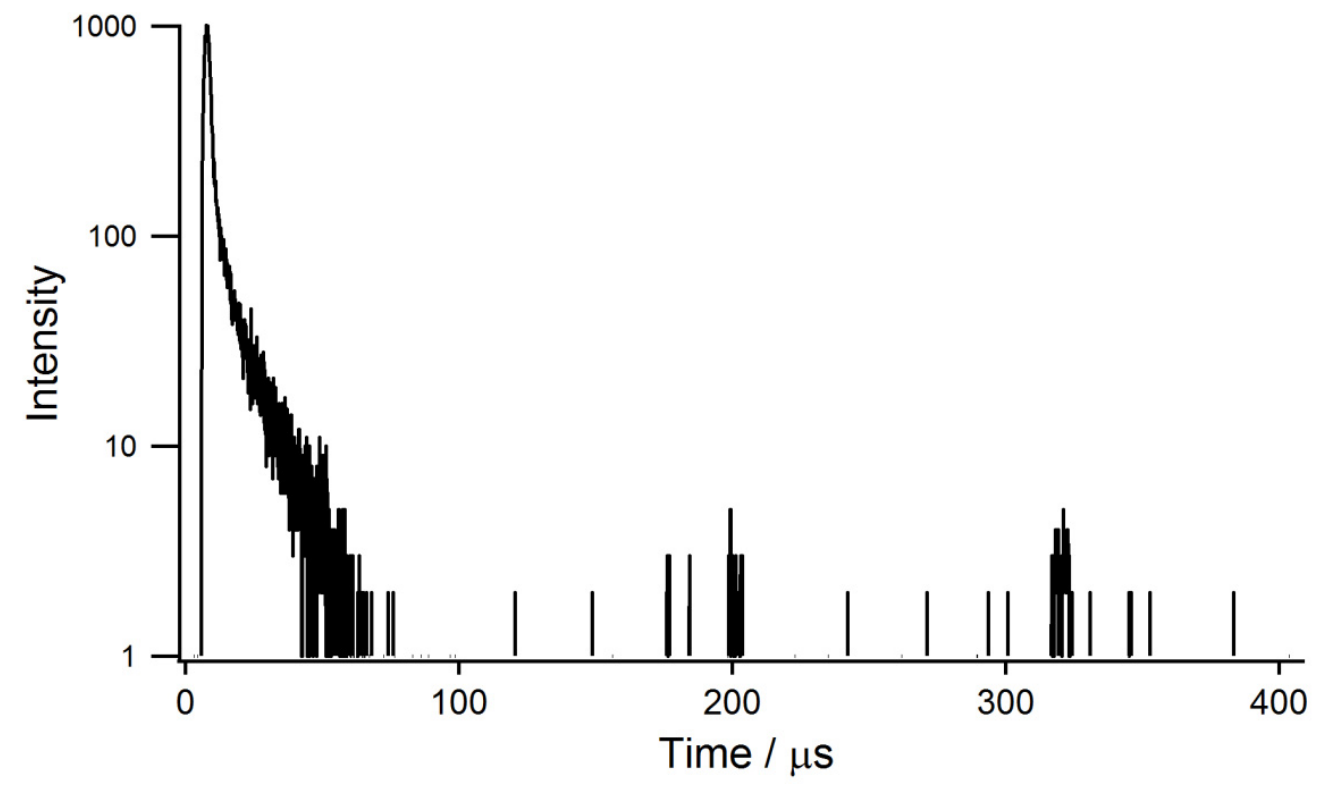

Figure S22. Emission decay profiles of $\mathbf{C F}_{3}-\mathbf{C N}$ in $\mathrm{CH}_{2} \mathrm{Cl}_{2}\left(c=6.4 \times 10^{-6} \mathrm{M}\right.$, rt). Excitation and monitored emission wavelength are 280 and $440 \mathrm{~nm}$, respectively. 


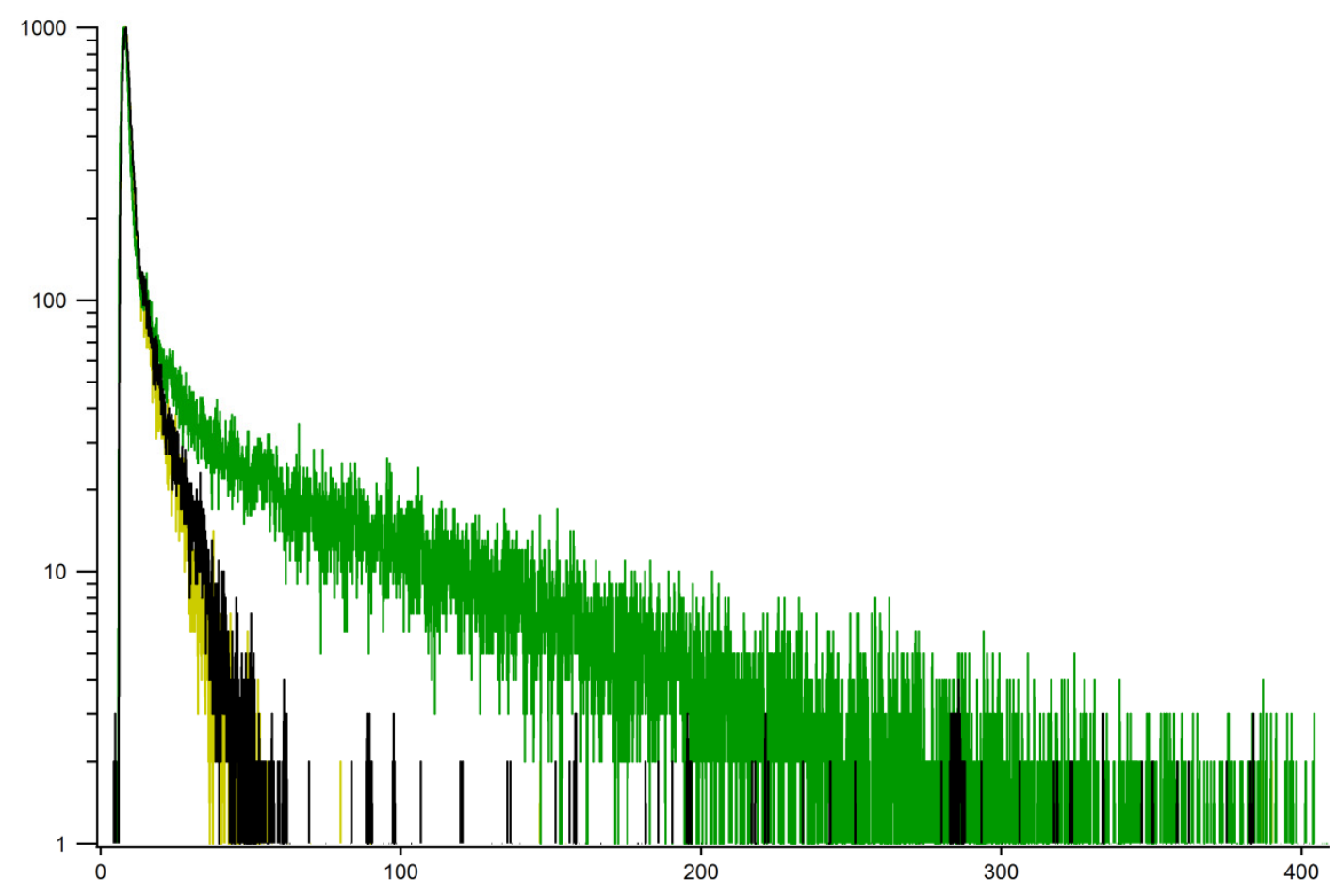

Figure S23. Emission decay profiles of $\mathbf{C F}_{\mathbf{3}}-\mathbf{C N}_{\mathbf{G}}$ at $518 \mathrm{~nm}$ (green line) and $\mathbf{C F}_{\mathbf{3}}-\mathbf{C N}_{\mathbf{Y}}$ at $576 \mathrm{~nm}$ (yellow line) and $\mathbf{C F}_{\mathbf{3}}-\mathbf{C N}_{\text {ground }}$ at $585 \mathrm{~nm}$ (black line) under excitation at $370 \mathrm{~nm}$.

Table S5. Photophysical properties of $\mathbf{C F}_{\mathbf{3}} \mathbf{- C N}$.

\begin{tabular}{|c|c|c|c|c|}
\hline & $\Phi_{e m} / \%$ & $\begin{array}{l}\tau_{\mathrm{av}} / \mu \mathrm{s}^{\mathrm{e}, \mathrm{f}} \\
\left(\lambda_{e m} / \mathrm{nm}\right)\end{array}$ & $\begin{array}{l}\tau_{1} / \mu \mathrm{s}^{\mathrm{e}} \\
(A /-)\end{array}$ & $\begin{array}{l}\tau_{2} / \mu \mathrm{s}^{\mathrm{e}} \\
(A /-)\end{array}$ \\
\hline $\mathrm{CF}_{3}-\mathrm{CN}_{\mathrm{G}}$ & $7.86^{\mathrm{a}}$ & $\begin{array}{l}47.1 \\
(518)\end{array}$ & $\begin{array}{l}0.324 \\
(0.99)\end{array}$ & $\begin{array}{l}96.3 \\
(0.01)\end{array}$ \\
\hline $\mathrm{CF}_{3}-\mathrm{CN}_{\mathbf{Y}}$ & $44.6^{\mathrm{b}}$ & $\begin{array}{l}0.746 \\
(576)\end{array}$ & $\begin{array}{l}0.746 \\
(1.00)\end{array}$ & - \\
\hline $\mathrm{CF}_{3}-\mathrm{CN}_{\text {ground }}$ & $23.1^{\mathrm{c}}$ & $\begin{array}{l}0.756 \\
(585)\end{array}$ & $\begin{array}{l}0.331 \\
(0.76)\end{array}$ & $\begin{array}{l}1.14 \\
(0.24)\end{array}$ \\
\hline $\mathrm{CF}_{3}-\mathrm{CN}_{\text {sol }}$ & $4.5^{\mathrm{d}}$ & 1.72 & $\begin{array}{l}0.331 \\
(0.80)\end{array}$ & $\begin{array}{l}6.902 \\
(0.20)\end{array}$ \\
\hline
\end{tabular}


$\underline{\text { 7. DSC Analysis of } \mathrm{CF}_{3}} \underline{\underline{\mathrm{CN}}} \underline{\underline{\mathrm{G}}} \underline{\text { and } \mathrm{CF}} \underline{\underline{3}}-\mathrm{CN}_{\underline{\mathrm{Y}}}$

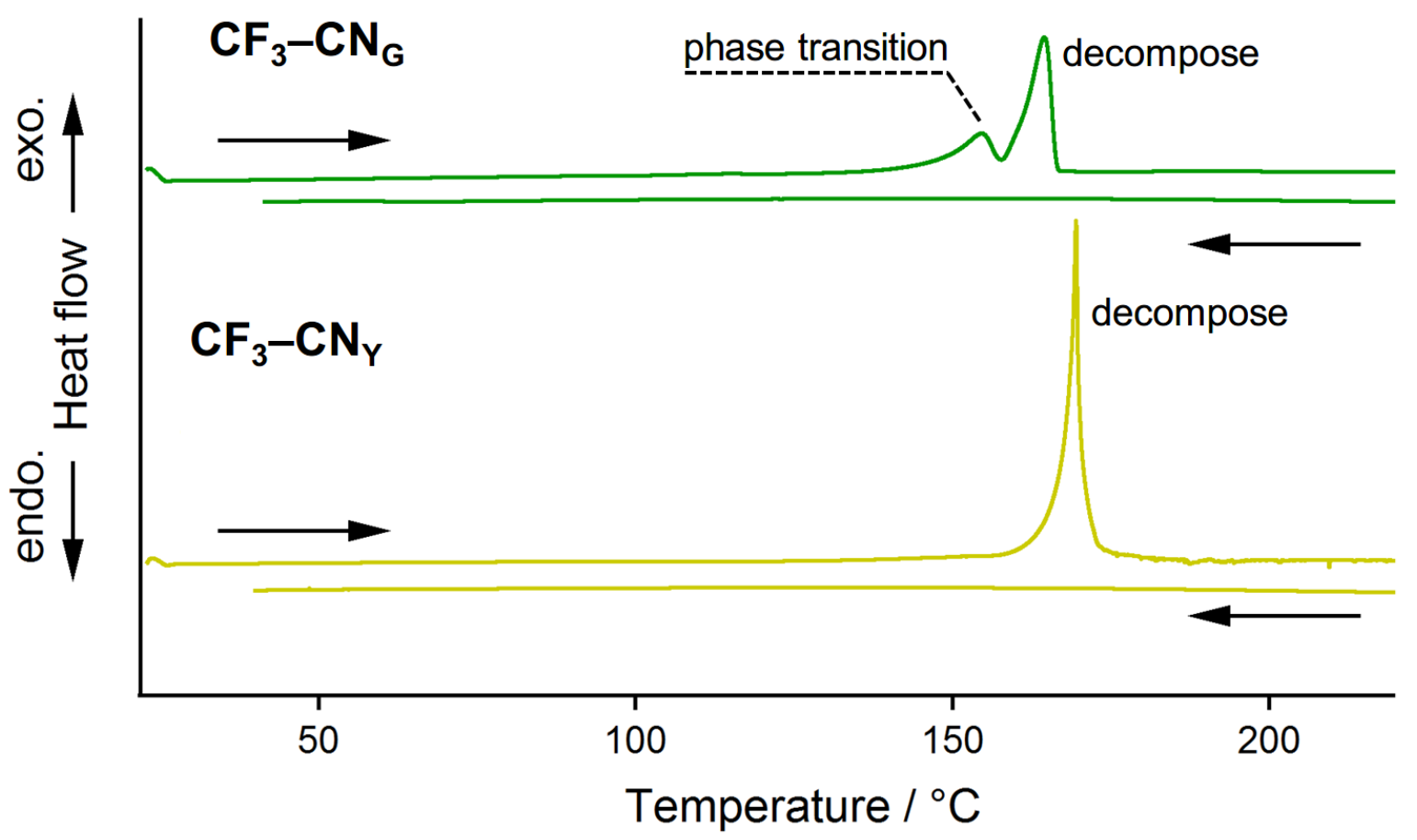

Figure S24. DSC profiles of $\mathbf{C F}_{\mathbf{3}}-\mathbf{C N}_{\mathbf{G}}$ (green line) and $\mathbf{C F}_{\mathbf{3}}-\mathbf{C N}_{\mathbf{Y}}$ (yellow line) at heating/cooling rate of $1{ }^{\circ} \mathrm{C} \min ^{-1}$ respectively. 


\section{Comparison of Powder Pattern of $\mathrm{CF}_{3}-\underline{C N}_{\underline{Y}} \underline{\text { and } \mathrm{CF}_{3}} \underline{\underline{\mathrm{CN}_{\text {ground }}}}$}

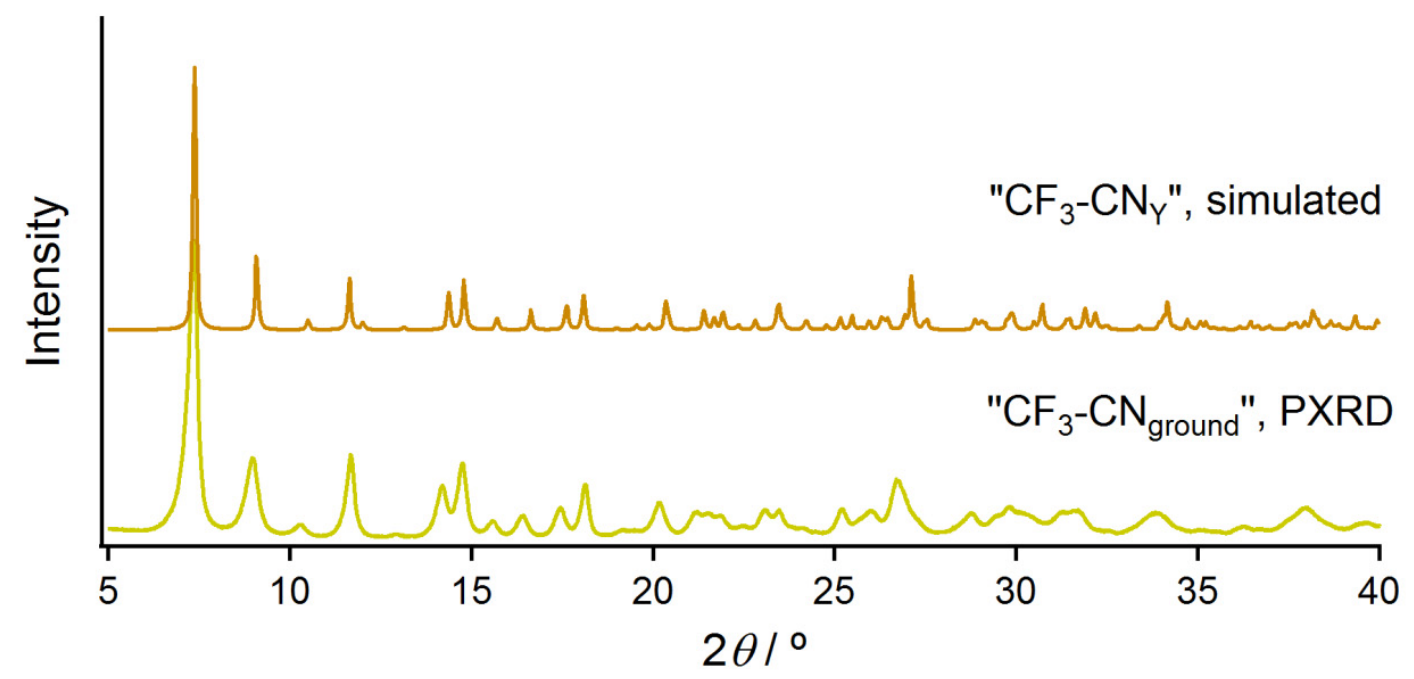

Figure S25. Simulated powder pattern derived from the single crystal $\mathbf{C F}_{\mathbf{3}}-\mathbf{C N}_{\mathbf{Y}}$ (upper pattern) and PXRD pattern (lower patterns) of $\mathbf{C F}_{\mathbf{3}}-\mathbf{C N}_{\text {ground }}$. 

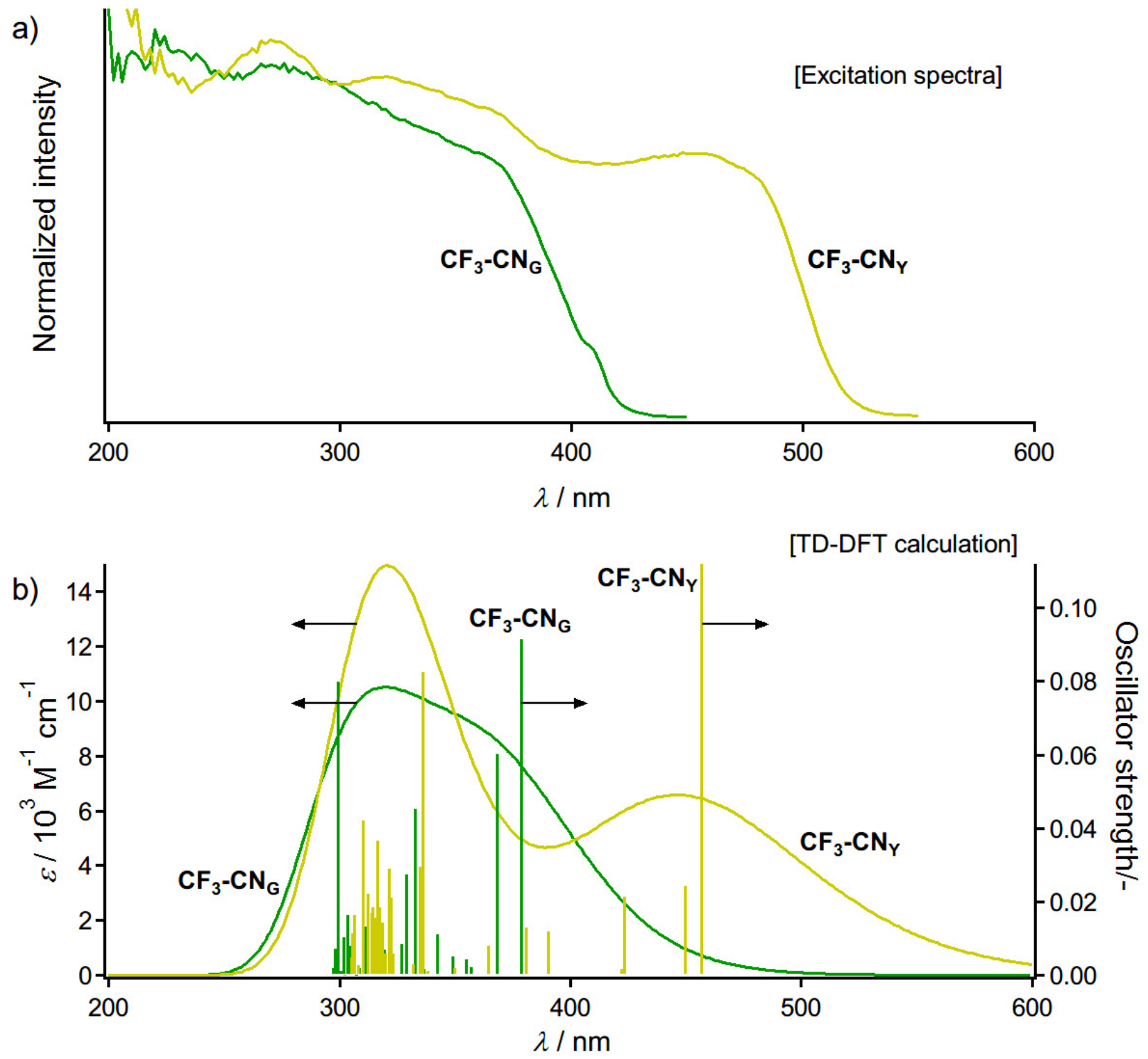

Figure S26. Comparison of experimental and theoretical studies on optical properties of $\mathbf{C F}_{\mathbf{3}}-\mathbf{C N}$. a) Normalized excitation spectra of $\mathbf{C F}_{\mathbf{3}}-\mathbf{C N}_{\mathbf{G}}$ (green line) and $\mathbf{C F}_{\mathbf{3}}-\mathbf{C N}_{\mathbf{Y}}$ (yellow line). The same spectra are shown in Figure 7c. b) Simulated UV/vis absorption spectra of $\mathbf{C F}_{\mathbf{3}}-\mathbf{C N}_{\mathbf{G}}$ (green curved line) and $\mathbf{C F}_{\mathbf{3}}-\mathbf{C N}_{\mathbf{Y}}$ (yellow curved line) based on the TD-DFT calculations of the tetramers derived from the corresponding single crystalline structures (B3LYP/SDD). Green and yellow straight lines indicate calculated oscillator strength of $\mathbf{C F}_{\mathbf{3}}-\mathbf{C N}_{\mathbf{G}}$ and $\mathbf{C F}_{\mathbf{3}}-\mathbf{C N}_{\mathbf{Y}}$, respectively.

Note: The excitation spectra for $\mathbf{C F}_{\mathbf{3}}-\mathbf{C N}_{\mathbf{G}}$ and $\mathbf{C F}_{\mathbf{3}}-\mathbf{C N}_{\mathbf{Y}}$ were well reproduced qualitatively by TD-DFT calculations using the tetramer structures derived from their X-ray single crystal structures. 


\section{Intermolecular Interactions in the Single Crystals of $R^{1}-R^{2}$}

Table S6. Summary of the intermolecular interactions found in the single crystal lattices of $\mathbf{R}^{1}-\mathbf{R}^{\mathbf{2}}$.

\begin{tabular}{|c|c|c|c|}
\hline Complex & $\begin{array}{l}\mathrm{CH}^{\cdots} \cdot \pi / \AA^{\mathrm{a}} \\
\text { (Threshold: } 2.9 \AA \text { ) }\end{array}$ & $\begin{array}{l}\pi \cdots \pi / \AA^{\mathrm{b}} \\
\text { (Threshold: } 3.6 \AA \text { ) }\end{array}$ & $\begin{array}{l}\mathrm{Au} \cdots \mathrm{Au} / \AA^{\mathrm{c}} \\
\text { (Threshold: } 3.6 \AA \text { ) }\end{array}$ \\
\hline OMe-Cl & - & $3.343 / 3.414$ & - \\
\hline $\mathrm{OMe}_{\mathrm{C}} \mathrm{CF}_{3}$ & 2.850 & - & - \\
\hline OMe-CN & - & $3.411 / 3.464$ & - \\
\hline Мe-OMe & $2.718 / 2.832$ & - & - \\
\hline Мe-Me & 2.723 & - & $-f^{f}$ \\
\hline Me-H ${ }^{\mathrm{d}}$ & $(N A)^{\mathbf{d}}$ & $(N A)^{\mathbf{d}}$ & $(N A)^{\mathbf{d}}$ \\
\hline Me-Cl & $2.630 / 2.630$ & - & - \\
\hline $\mathrm{Me}-\mathrm{CF}_{3}$ & $2.595 / 2.595 / 2.692 / 2.692$ & - & - \\
\hline $\mathrm{Me}-\mathrm{CN}$ & $2.683 / 2.683$ & - & 3.301 \\
\hline H-OMe $e^{e}$ & - & - & _g \\
\hline H-Me & $2.777 / 2.777$ & - & - \\
\hline $\mathbf{H}-\mathbf{H}^{\mathrm{S7}}$ & $2.815 / 2.815$ & - & - \\
\hline $\mathrm{H}-\mathrm{Cl}$ & - & $3.378 / 3.375 / 3.375 / 3.397$ & - \\
\hline $\mathrm{H}-\mathrm{CF}_{3}$ & $2.660 / 2.660$ & - & 3.591 \\
\hline $\mathrm{H}-\mathrm{CN}$ & - & $3.536 / 3.538 / 3.550 / 3.584$ & - \\
\hline $\mathrm{Cl}-\mathrm{CN}$ & - & $3.419 / 3.421$ & - \\
\hline $\mathrm{CF}_{3}-\mathrm{OMe}$ & - & - & 3.499 \\
\hline $\mathrm{CF}_{3}-\mathrm{Me}$ & - & - & 3.243 \\
\hline $\mathrm{CF}_{3}-\mathrm{H}$ & - & $3.452 / 3.469 / 3.476 / 3.520$ & - \\
\hline $\mathrm{CF}_{3}-\mathrm{Cl}$ & - & $3.586 / 3.586 / 3.590 / 3.590$ & - \\
\hline $\mathrm{CF}_{3}-\mathrm{CF}_{3}$ & - & - & 3.136 \\
\hline $\mathrm{CF}_{3}-\mathrm{CN}\left(\mathrm{CF}_{3}-\mathrm{CN}_{\mathrm{G}}\right)$ & $(2.908)^{\mathrm{h}}$ & - & - \\
\hline $\mathrm{CF}_{3}-\mathrm{CN}\left(\mathrm{CF}_{3}-\mathrm{CN}_{\mathbf{Y}}\right)$ & $2.649 / 2.762$ & 3.362 & $3.119 / 3.281$ \\
\hline CN-OMe & - & $3.394 / 3.416 / 3.461 / 3.479$ & 3.527 \\
\hline CN-Me & - & $3.336 / 3.388 / 3.431 / 3.493$ & - \\
\hline $\mathrm{CN}-\mathrm{Cl}$ & - & $3.384 / 3.437 / 3.490$ & - \\
\hline $\mathrm{CN}-\mathrm{CF}_{3}$ & - & $3.386 / 3.575$ & 3.462 \\
\hline $\mathrm{CN}-\mathrm{CN}$ & - & 3.449 & 3.309 \\
\hline
\end{tabular}

${ }^{\mathrm{a}}$ : $\mathrm{CH} \cdots \pi$ interactions are listed when distances between $\mathrm{H}$ atoms and a centroid of phenyl rings are less than $2.9 \AA .{ }^{\mathrm{b}}$ : $\pi \cdots \pi$ interactions are listed when distances between one phenyl plane and one of carbon atoms in a phenyl ring are less than $3.6 \AA$. $^{\mathrm{c}}: \mathrm{Au} \cdots \mathrm{Au}$ interactions are listed when distances between two gold atoms are less than $3.6 \AA .{ }^{\mathrm{d}}$ : Intermolecular interactions were not measured because whole molecules show heavily disorder. ${ }^{\mathrm{e}}:$ Double hydrogen bonds between $\mathrm{CH}_{3} \mathrm{O} \cdots \mathrm{HCH}_{2} \mathrm{O}$ with the distances of $2.674 \AA$ were observed. ${ }^{\mathrm{f}}$ : $\mathrm{Au}{ }^{\cdots} \pi \pi$ interaction with the distance between $\mathrm{Au}$ atom and a centroid of phenyl rings of $3.625 \AA$ exist. ${ }^{\mathrm{g}}$ : $\mathrm{Au}{ }^{\cdots} \pi \pi$ interaction with the distance between $\mathrm{Au}$ atom 
between $\mathrm{Au}$ atom and a centroid of phenyl rings of $3.625 \AA$ exist. $^{\mathrm{g}}$ : $\mathrm{Au}{ }^{\cdots} \pi \pi$ interaction with the distance between $\mathrm{Au}$ atom and a centroid of phenyl rings of $3.641 \AA$ exist. ${ }^{\text {h: }}$ This distance for a $\mathrm{CH} / \pi$ interaction is relatively long compared to those found in other crystals containing $\mathrm{CH} / \pi$ interactions. 


\section{Synthesis}

Zn powder (Wako Pure Chemical Industries, Ltd., 269-00212, Wako special grade, $\geq 90 \%$ ), $\mathrm{ZnBr}_{2}$ (267-00252, $\geq 95.0 \%$ ), and phosphate buffer solution $\left(025-03195, \mathrm{pH}\right.$ at $25^{\circ} \mathrm{C}$ is $\left.6.845 \sim 6.875\right)$ were purchased from Wako Pure Chemical Industries, Ltd. and used as received. Elemental analyses and high-resolution mass spectra were recorded at Global Facility Center, Creative Research Institution, Hokkaido University. According to the reported procedure, ${ }^{\mathrm{S} 8}$ para-substituted organozinc iodide reagents $\left(\mathbf{1}-\mathbf{R}^{1}, \mathrm{R}^{1}-\mathrm{C}_{6} \mathrm{H}_{4}-\mathrm{ZnI} \cdot \mathrm{LiCl} ; \mathrm{R}^{1}=\mathrm{H}, \mathrm{CF}_{3}\right.$, and $\left.\mathrm{CN}\right)$ were synthesized.

(i) General procedures for the synthesis of chloro(para-substituted phenyl isocyanide) gold(I) complexes 2-R $\mathbf{R}^{2}\left(\mathrm{R}^{2}=\mathrm{NMe}_{2}, \mathrm{OMe}, \mathrm{Me}, \mathrm{H}, \mathrm{Cl}, \mathrm{CF}_{3}, \mathrm{CN}\right.$, and $\left.\mathrm{NO}_{2}\right)$.

An example: the synthesis of $\mathbf{2 - N M e _ { 2 }}(i-1)$.

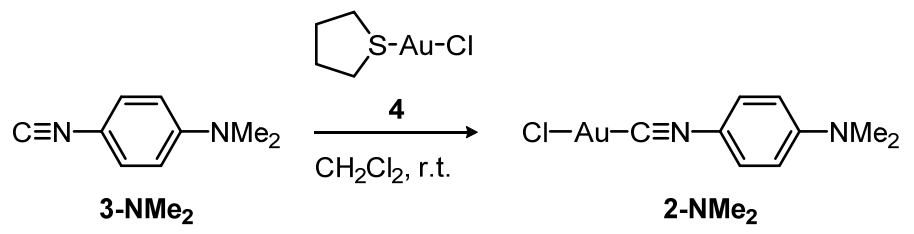

4- $N, N$-Dimethylphenyl isocyanide $\quad\left(3-\mathbf{N M e}_{2}, \quad 1.759 \quad \mathrm{~g}, \quad 12.0 \quad \mathrm{mmol}\right) \quad$ and chloro(tetrahydrothiophene)gold(I) (4, $3.209 \mathrm{~g}, 10.0 \mathrm{mmol})$ were dissolved in $\mathrm{CH}_{2} \mathrm{Cl}_{2}$ (100 mL) and stirred for $13.5 \mathrm{~h}$ at ambient condition. After the reaction completion was monitored by TLC analysis, the solvent was removed with a rotary evaporator under a reduced pressure. The residues are washed with methanol which gave an analytically pure yellow solid of $\mathbf{2 - N M \mathbf { N } _ { 2 }}$ (3.677 g, 9.71 mmol, 97\% yield).

${ }^{1} \mathrm{H}$ NMR (392 MHz, $\left.\mathrm{CDCl}_{3}, \delta\right): 3.06$ (s, 6H), 6.61-6.65 (m, 2H), 7.33 (d, $\left.J=9.0 \mathrm{~Hz}, 2 \mathrm{H}\right)$. ESI $(\mathrm{m} / z)$ : $[\mathrm{M}]^{+}$calcd for $\mathrm{C}_{9} \mathrm{H}_{10} \mathrm{ClN}_{2} \mathrm{Au}, 378.01980$; found, 378.01844. This compound exhibits poor solubility in common organic solvents (for example, maximum solubility in $\mathrm{CHCl}_{3}$ is $0.4 \mathrm{mg} / \mathrm{mL}$ ); therefore, ${ }^{13} \mathrm{C}$ NMR spectroscopy can not be measured.

(i-2) Synthesis of chloro(4-methoxyphenyl isocyanide)gold(I) (2-OMe). ${ }^{\mathrm{S} 9}$

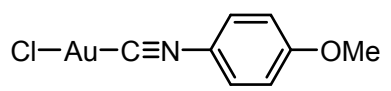

2-OMe was prepared from 3-OMe $(3.851 \mathrm{~g}, 28.9 \mathrm{mmol})$ and $4(6.418 \mathrm{~g}, 20.0 \mathrm{mmol})$ in $\mathrm{CH}_{2} \mathrm{Cl}_{2}(120$ $\mathrm{mL}$ ) according to the general procedure. Yield: $92 \%$ (6.763 g, $18.5 \mathrm{mmol}$, pale purple solid).

${ }^{1} \mathrm{H}$ NMR $\left(392 \mathrm{MHz}, \mathrm{CDCl}_{3}, \delta\right): 3.88(\mathrm{~s}, 3 \mathrm{H}), 6.95-6.99(\mathrm{~m}, 2 \mathrm{H}), 7.47(\mathrm{~d}, J=8.6 \mathrm{~Hz}, 2 \mathrm{H}) .{ }^{13} \mathrm{C}$ NMR $\left(99 \mathrm{MHz}, \mathrm{CDCl}_{3}, \delta\right): 55.8\left(\mathrm{CH}_{3}\right), 115.3(\mathrm{CH}), 116.7(C), 128.5(\mathrm{CH}), 140.6(C), 161.7(C)$. MS-FAB $(\mathrm{m} / \mathrm{z}):[\mathrm{M}]^{+}$calcd for $\mathrm{C}_{8} \mathrm{H}_{7} \mathrm{ONClAu}, 364.9882$; found, 364.9878 .

(i-3) Synthesis of chloro(4-methylphenyl isocyanide)gold(I) (2-Me). ${ }^{\text {S10 }}$ 


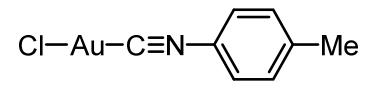

2-Me was prepared from 3-Me (1.073 g, $9.16 \mathrm{mmol})$ and 4 (2.447 g, $7.63 \mathrm{mmol})$ in $\mathrm{CH}_{2} \mathrm{Cl}_{2}(50 \mathrm{~mL})$ according to the general procedure. Yield: $90 \%$ (2.403 g, $6.87 \mathrm{mmol}$, white solid).

${ }^{1} \mathrm{H}$ NMR (392 MHz, $\left.\mathrm{CDCl}_{3}, \delta\right): 2.44$ (s, 3H), 7.30 (d, $\left.J=8.2 \mathrm{~Hz}, 2 \mathrm{H}\right), 7.42(\mathrm{~d}, J=8.6 \mathrm{~Hz}, 2 \mathrm{H}) .{ }^{13} \mathrm{C}$ NMR (99 MHz, $\left.\mathrm{CDCl}_{3}, \delta\right): 21.6\left(\mathrm{CH}_{3}\right), 121.6-121.9(\mathrm{~m}, \mathrm{C}), 126.7(\mathrm{CH}), 130.6(\mathrm{CH}), 140.4-140.9$ $(\mathrm{m}, \mathrm{C}), 142.6(\mathrm{C})$. MS-FAB $(\mathrm{m} / \mathrm{z})$ : $[\mathrm{M}+\mathrm{H}]^{+}$calcd for $\mathrm{C}_{8} \mathrm{H}_{8} \mathrm{NClAu}, 350.0011$; found, 350.0010 .

(i-4) Synthesis of chloro(4-chlorophenyl isocyanide)gold(I) (2-Cl).

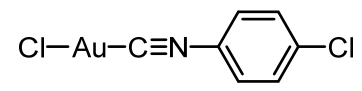

2-Cl was prepared from 3-Cl (3.307 g, $24.0 \mathrm{mmol})$ and 4 (6.413 g, $20.0 \mathrm{mmol})$ in $\mathrm{CH}_{2} \mathrm{Cl}_{2}(100 \mathrm{~mL})$ according to the general procedure. Yield: $97 \%$ (7.224 g, $19.5 \mathrm{mmol}$, white solid).

${ }^{1} \mathrm{H}$ NMR (392 MHz, $\left.\mathrm{CDCl}_{3}, \delta\right): 7.48-7.53$ (m, 4H). ${ }^{13} \mathrm{C}$ NMR (99 MHz, $\left.\mathrm{CDCl}_{3}, \delta\right): 122.8(C), 128.1$ $(C H), 130.5(C H), 138.3(C), 142.5(C)$. MS-ESI $(m / z)$ : $[\mathrm{M}]^{+}$calcd for $\mathrm{C}_{7} \mathrm{H}_{4} \mathrm{Cl}_{2} \mathrm{NAuNa}, 391.9284$; found, 391.9277.

(i-5) Synthesis of chloro(4-trifluoromethylphenyl isocyanide)gold(I) (2-CF $\mathbf{3})$.

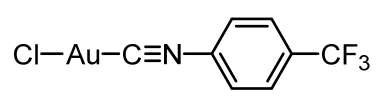

2-CF $\mathbf{3}$ was prepared from 3-CF $\mathbf{3}(3.960 \mathrm{~g}, 23.1 \mathrm{mmol})$ and $\mathbf{4}(6.194 \mathrm{~g}, 19.3 \mathrm{mmol})$ in $\mathrm{CH}_{2} \mathrm{Cl}_{2}(100$ $\mathrm{mL}$ ) according to the general procedure. Yield: $96 \%$ (7.495 g, $18.6 \mathrm{mmol}$, white solid).

${ }^{1} \mathrm{H}$ NMR (392 MHz, $\left.\mathrm{CDCl}_{3}, \delta\right): 7.71(\mathrm{~d}, J=7.8 \mathrm{~Hz}, 2 \mathrm{H}), 7.82$ (d, $\left.J=8.6 \mathrm{~Hz}, 2 \mathrm{H}\right)$. MS-FAB $(\mathrm{m} / z)$ : $[\mathrm{M}+\mathrm{Na}]^{+}$calcd for $\mathrm{C}_{8} \mathrm{H}_{4} \mathrm{NClF}_{3} \mathrm{NaAu}$, 425.9548; found, 425.9545. This compound exhibits low solubility in common organic solvents (for example, maximum solubility in $\mathrm{CHCl}_{3}$ is $16 \mathrm{mg} / \mathrm{mL}$ ). ${ }^{13} \mathrm{C}$ NMR spectrum of $\mathbf{2}-\mathbf{C F}_{\mathbf{3}}$ was recorded for $12 \mathrm{~h}$ by using its saturated $\mathrm{CDCl}_{3}$ solution; however, we cannot detect all the expected signals of this compound.

(i-6) Synthesis of chloro(4-cyanophenyl isocyanide)gold(I) (2-CN).

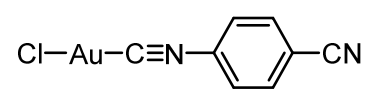

2-CN was prepared from 3-CN $(768.9 \mathrm{mg}, 6.00 \mathrm{mmol})$ and $4(1.603 \mathrm{~g}, 5.00 \mathrm{mmol})$ in $\mathrm{CH}_{2} \mathrm{Cl}_{2}(80$ $\mathrm{mL}$ ) according to the general procedure. Yield: $98 \%$ (1.771 g, $4.91 \mathrm{mmol}$, white solid).

${ }^{1} \mathrm{H}$ NMR (392 MHz, $\left.\mathrm{CDCl}_{3}, \delta\right):$ 7.69-7.72 (m, 2H), 7.85-7.88 (m, 2H). MS-ESI $(\mathrm{m} / \mathrm{z})$; $[\mathrm{M}+\mathrm{Na}]^{+}$ calcd for $\mathrm{C}_{8} \mathrm{H}_{4} \mathrm{AuClN}{ }_{2} \mathrm{Na}, 382.9626$; found, 382.9630. This compound exhibits poor solubility in 
common organic solvents (for example, maximum solubility in $\mathrm{CHCl}_{3}$ is $<0.1 \mathrm{mg} / \mathrm{mL}$ ); therefore, ${ }^{13} \mathrm{C}$ NMR spectroscopy can not be measured.

(i-7) Synthesis of chloro(4-nitrophenyl isocyanide)gold(I) (2-NO2). ${ }^{\mathrm{S} 11}$

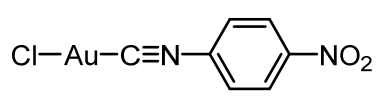

2-NO $\mathbf{N O}_{2}$ was prepared from 3-NO $(2.221 \mathrm{~g}, 15.0 \mathrm{mmol})$ and $4(4.009 \mathrm{~g}, 12.5 \mathrm{mmol})$ in $\mathrm{CH}_{2} \mathrm{Cl}_{2}(100$ $\mathrm{mL}$ ) according to the general procedure. Yield: $98 \%$ (4.667 g, $12.3 \mathrm{mmol}$, pale yellow solid). ${ }^{1} \mathrm{H}$ NMR (392 MHz, $\left.\mathrm{CDCl}_{3}, \delta\right): 7.70-7.81$ (m, 2H), 8.41-8.45 (m, 2H). MS-ESI $(\mathrm{m} / \mathrm{z})$; $[\mathrm{M}+\mathrm{Na}]^{+}$ calcd for $\mathrm{C}_{7} \mathrm{H}_{4} \mathrm{AuClN} \mathrm{NaO}_{2}, 402.9525$; found, 402.95117. This compound exhibits poor solubility in common organic solvents (for example, maximum solubility in $\mathrm{CHCl}_{3}$ is $0.5 \mathrm{mg} / \mathrm{mL}$ ); therefore, ${ }^{13} \mathrm{C}$ NMR spectroscopy can not be measured. 
(ii) General procedures of the synthesis of $\mathbf{R}^{\mathbf{1}}-\mathbf{R}^{\mathbf{2}}$ (Method I and Method II)

Preparation of $48 \mathbf{R}^{1}-\mathbf{R}^{2}$ complexes $\left(\mathrm{R}^{1}=\mathrm{OMe}, \mathrm{Me}, \mathrm{H}, \mathrm{Cl}, \mathrm{CF}_{3}\right.$, and $\mathrm{CN} ; \mathrm{R}^{2}=\mathrm{NMe}_{2}, \mathrm{OMe}, \mathrm{Me}, \mathrm{H}$, $\mathrm{Cl}, \mathrm{CF}_{3}, \mathrm{CN}$, and $\mathrm{NO}_{2}$ ) was carried out by using either Method I or Method II described below.

Method I; An example: the synthesis of OMe-NMe $\underline{N}_{2}(i i-1)$.

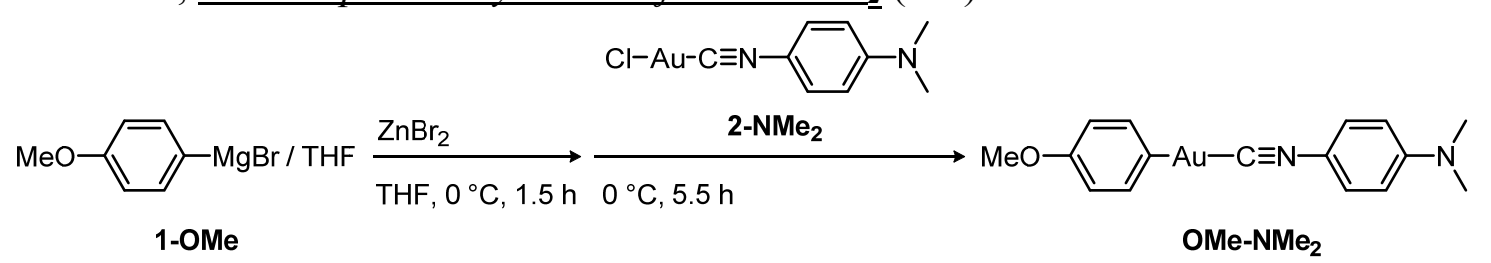

A powder of zinc bromide $(1.013 \mathrm{~g}, 4.50 \mathrm{~mol})$ was placed in an oven-dried two-neck flask. The flask was connected to a vacuum/nitrogen manifold through a rubber tube. It was evacuated and then backfilled with nitrogen. This cycle was repeated three times. THF ( $4.5 \mathrm{~mL})$ was then added in the flask through the rubber septum using a syringe, and stirred at $0{ }^{\circ} \mathrm{C}$. A 4-methoxyphenylmagnesium bromide reagent $(\mathbf{1 - O M e})$ in THF $(6.16 \mathrm{ml}, 4.50 \mathrm{mmol}, 0.73 \mathrm{M})$ was then added to the reaction mixture using a syringe, and stirred at $0{ }^{\circ} \mathrm{C}$ for $1 \mathrm{~h}$. Then, a powder of $\mathbf{2}-\mathbf{N M e}_{\mathbf{2}}(1.136 \mathrm{~g}, 3.00 \mathrm{mmol})$ was added and the mixture was stirred at $0{ }^{\circ} \mathrm{C}$. After the reaction completion was monitored by TLC analysis, the reaction mixture was quenched by the addition of a phosphate buffer solution $(5.0 \mathrm{~mL})$ and then extracted with $\mathrm{CH}_{2} \mathrm{Cl}_{2}(100 \mathrm{~mL})$ three times and washed with brine $(200 \mathrm{~mL})$. The organic layers were collected and dried over $\mathrm{MgSO}_{4}$. After filtration, the solvent was removed in vacuo. Further purification was performed through the repeated washing by using hexane or methanol to give an analytically pure grey solid of $\mathbf{O M e}-\mathbf{N M e}_{2}(1.052 \mathrm{~g}, 2.34 \mathrm{mmol}, 78 \%$ yield).

${ }^{1} \mathrm{H}$ NMR (392 MHz, $\mathrm{CDCl}_{3}, \delta$ ): 3.04 (s, 6H), 3.78 (s, 3H), 6.62 (d, J=9.0 Hz, 2H), 6.86 (d, J=8.6 $\mathrm{Hz}, 2 \mathrm{H}), 7.33(\mathrm{~d}, J=9.0 \mathrm{~Hz}, 2 \mathrm{H}), 7.41(\mathrm{~d}, J=8.6 \mathrm{~Hz}, 2 \mathrm{H}) .{ }^{13} \mathrm{C} \mathrm{NMR}\left(99 \mathrm{MHz}, \mathrm{CDCl}_{3}, \delta\right): 40.1$ $\left(\mathrm{CH}_{3}\right), 54.9\left(\mathrm{CH}_{3}\right), 111.7(\mathrm{CH}), 112.0(\mathrm{C}), 113.2(\mathrm{CH}), 127.7(\mathrm{CH}), 140.7(\mathrm{CH}), 151.2(\mathrm{C}), 154.2(\mathrm{C})$, $158.0(C), 160.6(C)$. MS-FAB $(m / z):[\mathrm{M}+\mathrm{Na}]^{+}$calcd for $\mathrm{C}_{16} \mathrm{H}_{17} \mathrm{ON}_{2} \mathrm{NaAu}, 473.0904$; found, 473.0908 .

Method II; An example: the synthesis of $\mathrm{CF}_{3} \underline{-N_{M} \underline{e}_{2}}($ ii-33).

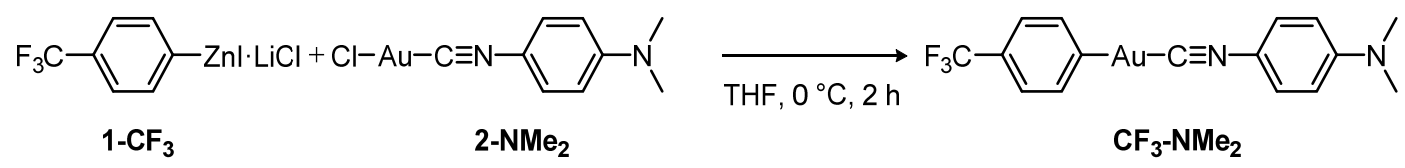

A powder of $\mathbf{2}-\mathbf{N M e}_{2}(749.0 \mathrm{mg}, 1.86 \mathrm{mmol})$ was placed in an oven-dried two-neck flask. The flask was connected to a vacuum/nitrogen manifold through a rubber tube. It was evacuated and then backfilled with nitrogen. This cycle was repeated three times. THF $(3.0 \mathrm{~mL})$ was then added in the flask through the rubber septum using a syringe, and stirred at $0{ }^{\circ} \mathrm{C}$. An organozinc iodide reagent $\mathbf{1}_{-} \mathbf{C F}_{\mathbf{3}}$ in THF (2.84 $\left.\mathrm{ml}, 2.78 \mathrm{mmol}, 0.98 \mathrm{M}\right)$ was then added to the reaction mixture using a syringe, 
and stirred at $0{ }^{\circ} \mathrm{C}$ for $2.5 \mathrm{~h}$. After the reaction completion was monitored by TLC analysis, the reaction mixture was quenched by the addition of a phosphate buffer solution $(5.0 \mathrm{~mL})$ and then extracted with $\mathrm{CH}_{2} \mathrm{Cl}_{2}(100 \mathrm{~mL})$ three times and washed with brine $(200 \mathrm{~mL})$. The organic layers were collected and dried over $\mathrm{MgSO}_{4}$. After filtration, the solvent was removed in vacuo. Further purification was performed through the repeated washing by using hexane or methanol to give an analytically pure pale yellow solid of $\mathbf{C F}_{3}-\mathbf{N M e}_{2}$ (833.2 $\mathrm{mg}, 1.69 \mathrm{mmol}, 91 \%$ yield).

${ }^{1} \mathrm{H}$ NMR (401 MHz, $\left.\mathrm{CDCl}_{3}, \delta\right): 3.05$ (s, 6H), 6.60-6.64 (m, 2H), $7.32(\mathrm{~d}, J=9.2 \mathrm{~Hz}, 2 \mathrm{H}), 7.45(\mathrm{~d}, J$ $=7.2 \mathrm{~Hz}, 2 \mathrm{H}), 7.56(\mathrm{~d}, J=7.6 \mathrm{~Hz}, 2 \mathrm{H}) .{ }^{13} \mathrm{C} \mathrm{NMR}\left(99 \mathrm{MHz}, \mathrm{CDCl}_{3}, \delta\right): 40.1\left(\mathrm{CH}_{3}\right), 111.7(\mathrm{CH})$, $111.9(C), 123.3\left(\mathrm{~d},{ }^{3} J_{\mathrm{C}-\mathrm{F}}=3.8 \mathrm{~Hz}, C \mathrm{H}\right), 124.7$ (q, $\left.{ }^{1} J_{\mathrm{C}-\mathrm{F}}=273 \mathrm{~Hz}, C \mathrm{~F}_{3}\right), 127.4\left(\mathrm{q},{ }^{2} J_{\mathrm{C}-\mathrm{F}}=32 \mathrm{~Hz}, C\right.$ ), $127.8(C \mathrm{H}), 140.1(\mathrm{CH}), 151.3(C), 159.3-159.7(\mathrm{~m}, C), 167.9(C)$. MS-FAB $(\mathrm{m} / \mathrm{z}):[\mathrm{M}+\mathrm{Na}]^{+}$calcd for $\mathrm{C}_{16} \mathrm{H}_{14} \mathrm{~F}_{3} \mathrm{~N}_{2} \mathrm{AuNa}$, 511.0672; found, 511.0660.

(ii-2) Synthesis of OMe-OMe (Method I).

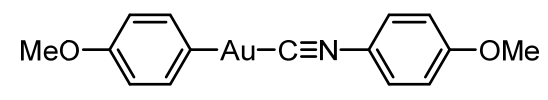

OMe-OMe was prepared from 2-OMe $(730.7 \mathrm{mg}, 2.00 \mathrm{mmol})$ and 4-methoxyphenylmagnesium bromide reagent (1-OMe) in THF (3.89 ml, $3.00 \mathrm{mmol}, 0.77 \mathrm{M}$ ) according to Method I. Yield: $67 \%$ (582.8 mg, $1.33 \mathrm{mmol}$, white solid).

${ }^{1} \mathrm{H}$ NMR (392 MHz, $\left.\mathrm{CDCl}_{3}, \delta\right): 3.78$ (s, 3H), 3.87 (s, 3H), 6.87 (d, J=8.6 Hz, 2H), 6.93-6.97 (m, 2H), 7.39-7.54 (m, 4H). ${ }^{13} \mathrm{C} \mathrm{NMR}\left(99 \mathrm{MHz}, \mathrm{CDCl}_{3}, \delta\right): 54.9\left(\mathrm{CH}_{3}\right), 55.7\left(\mathrm{CH}_{3}\right), 113.2(\mathrm{CH}), 115.1$ $(C H), 117.4(C), 128.2(C H), 140.7(C H), 154.0(C), 158.0(C), 161.1(C), 161.2(C)$. MS-FAB $(m / z)$ : $[\mathrm{M}]^{+}$calcd for $\mathrm{C}_{15} \mathrm{H}_{14} \mathrm{O}_{2} \mathrm{NAu}, 437.0690$; found, 437.0679 .

(ii-3) Synthesis of OMe-Me (Method I).

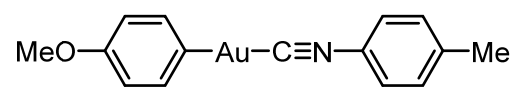

OMe-Me was prepared from 2-Me $(699.4 \mathrm{mg}, 2.00 \mathrm{mmol})$ and 4-methoxyphenylmagnesium bromide reagent (1-OMe) in THF $(3.89 \mathrm{ml}, 3.00 \mathrm{mmol}, 0.77 \mathrm{M})$ according to Method I. Yield: 51\% (437.3 mg, $1.04 \mathrm{mmol}$, white solid).

${ }^{1} \mathrm{H}$ NMR (392 MHz, $\left.\mathrm{CDCl}_{3}, \delta\right): 2.42$ (s, 3H), 3.78 (s, 3H), 6.87 (d, J=8.6 Hz, 2H), 7.26-7.29 (m, 2H), 7.39-7.41 (m, 2H). ${ }^{13} \mathrm{C} \mathrm{NMR}\left(99 \mathrm{MHz}, \mathrm{CDCl}_{3}, \delta\right): 21.5\left(\mathrm{CH}_{3}\right), 54.9\left(\mathrm{CH}_{3}\right), 113.1(\mathrm{CH}), 122.3$ $(C), 126.4(\mathrm{CH}), 130.4(\mathrm{CH}), 140.8(\mathrm{CH}), 141.7(\mathrm{C}), 154.0(\mathrm{C}), 157.9(\mathrm{C}), 161.1(\mathrm{C})$. MS-FAB $(\mathrm{m} / \mathrm{z})$ : $[\mathrm{M}]^{+}$calcd for $\mathrm{C}_{15} \mathrm{H}_{14} \mathrm{ONAu}, 421.0741$; found, 421.0743 .

(ii-4) Synthesis of OMe-H (Method I). 


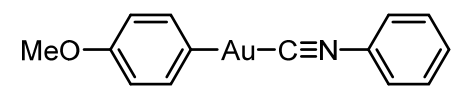

OMe-H was prepared from 2-H (1.008 g, $3.00 \mathrm{mmol})$ and 4-methoxyphenylmagnesium bromide reagent (1-OMe) in THF $(6.16 \mathrm{ml}, 4.50 \mathrm{mmol}, 0.73 \mathrm{M})$ according to Method I. Yield: 29\% (357.7 $\mathrm{mg}, 0.878 \mathrm{mmol}$, pale purple solid).

${ }^{1} \mathrm{H}$ NMR (396 MHz, $\left.\mathrm{CDCl}_{3}, \delta\right): 3.79$ (s, 3H), 6.88 (d, $\left.J=8.6 \mathrm{~Hz}, 2 \mathrm{H}\right), 7.40$ (d, J=7.8 Hz, 2H), 7.48-7.57 (m, 5H);. ${ }^{13} \mathrm{C}$ NMR (99 MHz, $\left.\mathrm{CDCl}_{3}, \delta\right): 54.9\left(\mathrm{CH}_{3}\right), 113.2(\mathrm{CH}), 125.0(\mathrm{C}), 126.6(\mathrm{CH})$, $129.9(\mathrm{CH}), 131.1(\mathrm{CH}), 140.7(\mathrm{CH}), 153.9(\mathrm{C}), 158.1(\mathrm{CH}), 161.7(\mathrm{C})$. MS-FAB $(\mathrm{m} / \mathrm{z}):[\mathrm{M}]^{+}$calcd for $\mathrm{C}_{14} \mathrm{H}_{12} \mathrm{ONAu}$, 407.0584; found, 407.0579 .

(ii-5) Synthesis of OMe-Cl (Method I).

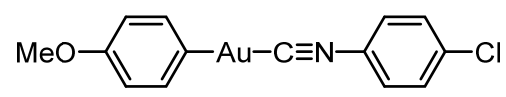

OMe-Cl was prepared from 2-Cl (1.014 g, $2.74 \mathrm{mmol})$ and 4-methoxyphenylmagnesium bromide reagent (1-OMe) in THF $(5.84 \mathrm{ml}, 4.50 \mathrm{mmol}, 0.77 \mathrm{M})$ according to Method I. Yield: $63 \%$ (770.1 $\mathrm{mg}, 1.74 \mathrm{mmol}$, pale purple solid).

${ }^{1} \mathrm{H}$ NMR (392 MHz, $\left.\mathrm{CDCl}_{3}, \delta\right): 3.78$ (s, 3H), 6.87 (d, $\left.J=8.6 \mathrm{~Hz}, 2 \mathrm{H}\right), 7.39$ (d, $\left.J=8.6 \mathrm{~Hz}, 2 \mathrm{H}\right)$, 7.44-7.50 (m, 4H). ${ }^{13} \mathrm{C}$ NMR (99 MHz, $\left.\mathrm{CDCl}_{3}, \delta\right): 54.9\left(\mathrm{CH}_{3}\right), 113.2(\mathrm{CH}), 123.4(C), 127.9(\mathrm{CH})$, $130.3(\mathrm{CH}), 137.4(C), 140.7(\mathrm{CH}), 153.8(C), 158.1(C), 163.0(C)$. MS-FAB $(\mathrm{m} / z):[\mathrm{M}]^{+}$calcd for $\mathrm{C}_{14} \mathrm{H}_{11} \mathrm{ClNOAu}, 441.0195$; found, 441.0197.

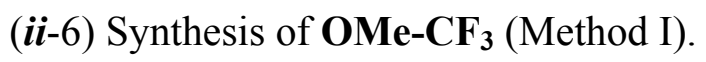

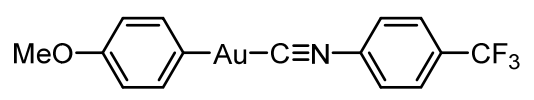

OMe- $\mathbf{C F}_{\mathbf{3}}$ was prepared from $\mathbf{2}-\mathbf{C F}_{\mathbf{3}}(1.211 \mathrm{~g}, 3.00 \mathrm{mmol})$ and 4-methoxyphenylmagnesium bromide reagent (1-OMe) in THF (7.06 ml, $4.50 \mathrm{mmol}, 0.64 \mathrm{M})$ according to Method I. Yield: 43\% (624.7 $\mathrm{mg}, 1.31 \mathrm{mmol}$, gray solid).

${ }^{1} \mathrm{H}$ NMR (392 MHz, $\left.\mathrm{CDCl}_{3}, \delta\right): 3.79$ (s, 3H), 6.87 (d, $\left.J=8.6 \mathrm{~Hz}, 2 \mathrm{H}\right), 7.40(\mathrm{~d}, J=8.6 \mathrm{~Hz}, 2 \mathrm{H}), 7.67$ $(\mathrm{d}, J=8.2 \mathrm{~Hz}, 2 \mathrm{H}), 7.79(\mathrm{~d}, J=8.6 \mathrm{~Hz}, 2 \mathrm{H}) .{ }^{13} \mathrm{C} \mathrm{NMR}\left(99 \mathrm{MHz}, \mathrm{CDCl}_{3}, \delta\right): 54.9\left(\mathrm{CH}_{3}\right), 113.2(\mathrm{CH})$, $123.0\left(\mathrm{q},{ }^{1} J_{\mathrm{C}-\mathrm{F}}=274 \mathrm{~Hz}, C \mathrm{~F}_{3}\right), 127.1\left(\mathrm{~d},{ }^{3} J_{\mathrm{C}-\mathrm{F}}=3.8 \mathrm{~Hz}, C \mathrm{H}\right), 127.2(\mathrm{CH}), 127.9(C), 132.9\left(\mathrm{q},{ }^{2} J_{\mathrm{C}-\mathrm{F}}\right.$ $=34 \mathrm{~Hz}, C), 140.8(\mathrm{CH}), 153.9(\mathrm{C}), 158.2(\mathrm{C}), 163.8(\mathrm{C})$. MS-FAB $(\mathrm{m} / \mathrm{z}):[\mathrm{M}]^{+}$calcd for $\mathrm{C}_{15} \mathrm{H}_{11} \mathrm{ONF}_{3} \mathrm{Au}, 475.0458$; found, 475.0459.

(ii-7) Synthesis of OMe-CN (Method I). 


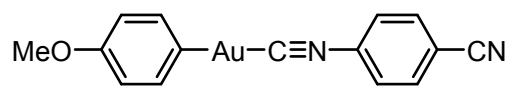

OMe- $\mathbf{C F}_{3}$ was prepared from $\mathbf{2}-\mathbf{C F}_{\mathbf{3}}(180.3 \mathrm{mg}, 0.500 \mathrm{mmol})$ and 4-methoxyphenylmagnesium bromide reagent (1-OMe) in THF (1.03 ml, $0.750 \mathrm{mmol}, 0.73 \mathrm{M})$ according to Method I. Yield: $64 \%$ (138.2 mg, $0.319 \mathrm{mmol}$, gray solid).

${ }^{1} \mathrm{H}$ NMR (392 MHz, $\mathrm{CDCl}_{3}, \delta$ ): 3.79 (s, 3H), 6.86-6.89 (m, 2H), 7.38 (dd, $\left.J=2.4,8.2 \mathrm{~Hz}, 2 \mathrm{H}\right), 7.67$ $(\mathrm{d}, J=8.6 \mathrm{~Hz}, 2 \mathrm{H}), 7.83(\mathrm{dd}, J=2.0,6.7 \mathrm{~Hz}, 2 \mathrm{H})$. MS-FAB $(\mathrm{m} / z)$ : $[\mathrm{M}]^{+}$calcd for $\mathrm{C}_{15} \mathrm{H}_{11} \mathrm{ON}_{2} \mathrm{Au}$, 432.0537; found, 432.0536. This compound exhibits poor solubility in common organic solvents (for example, maximum solubility in $\mathrm{CHCl}_{3}$ is $2 \mathrm{mg} / \mathrm{mL}$ ); therefore, ${ }^{13} \mathrm{C}$ NMR spectroscopy can not be measured.

(ii-8) Synthesis of OMe-NO $\mathbf{O M}_{2}$ (Method I).

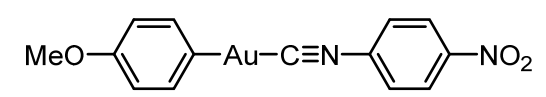

OMe-NO $\mathbf{N}_{2}$ was prepared from 2-NO2 $(190.8 \mathrm{mg}, 0.500 \mathrm{mmol})$ and 4-methoxyphenylmagnesium bromide reagent (1-OMe) in THF (1.03 ml, $0.750 \mathrm{mmol}, 0.73 \mathrm{M})$ according to Method I. Yield: 49\% (110.4 mg, $0.244 \mathrm{mmol}$, yellow solid).

${ }^{1} \mathrm{H}$ NMR (396 MHz, $\mathrm{CDCl}_{3}, \delta$ ): 3.79 (s, 3H), 6.88 (d, $\left.J=8.6 \mathrm{~Hz}, 2 \mathrm{H}\right), 7.39$ (d, $\left.J=8.6 \mathrm{~Hz}, 2 \mathrm{H}\right), 7.74$ $(\mathrm{d}, J=8.2 \mathrm{~Hz}, 2 \mathrm{H}), 8.40(\mathrm{~d}, J=9.0 \mathrm{~Hz}, 2 \mathrm{H})$. MS-FAB $(m / z):[\mathrm{M}]^{+}$calcd for $\mathrm{C}_{14} \mathrm{H}_{11} \mathrm{AuN}_{2} \mathrm{O}_{3}$, 452.0435; found, 452.0442. This compound exhibits poor solubility in common organic solvents (for example, maximum solubility in $\mathrm{CHCl}_{3}$ is $0.8 \mathrm{mg} / \mathrm{mL}$ ); therefore, ${ }^{13} \mathrm{C}$ NMR spectroscopy can not be measured.

(ii-9) Synthesis of Me-NMe 2 (Method I).

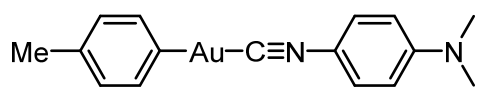

Me-NMe 2 was prepared from 2-NMe $(759.5 \mathrm{mg}, 2.00 \mathrm{mmol})$ and 4-methylphenylmagnesium bromide reagent (1-Me) in THF $(6.00 \mathrm{ml}, 3.00 \mathrm{mmol}, 0.50 \mathrm{M})$ according to Method I. Yield: $69 \%$ (602.1 mg, $1.39 \mathrm{mmol}$, gray solid).

${ }^{1} \mathrm{H}$ NMR (392 MHz, $\left.\mathrm{CDCl}_{3}, \delta\right): 2.31$ (s, 3H), 3.04 (s, 6H), 6.58-6.65 (m, 2H), 7.07 (d, J = 7.4 Hz, $2 \mathrm{H}), 7.31(\mathrm{~d}, J=9.0 \mathrm{~Hz}, 2 \mathrm{H}), 7.35(\mathrm{~d}, J=7.8 \mathrm{~Hz}, 2 \mathrm{H}) .{ }^{13} \mathrm{C} \mathrm{NMR}\left(99 \mathrm{MHz}, \mathrm{CDCl}_{3}, \delta\right): 21.3\left(\mathrm{CH}_{3}\right)$, $40.1\left(\mathrm{CH}_{3}\right), 111.7(\mathrm{CH}), 112.0-112.2(\mathrm{~m}, \mathrm{C}), 127.7(\mathrm{CH}), 128.2(\mathrm{CH}), 135.2(\mathrm{C}), 140.0(\mathrm{CH}), 151.1$ (C), $159.1(C), 160.5-161.0(\mathrm{~m}, C)$. MS-FAB $(\mathrm{m} / \mathrm{z})$ : $[\mathrm{M}+\mathrm{Na}]^{+}$calcd for $\mathrm{C}_{16} \mathrm{H}_{17} \mathrm{AuN}_{2} \mathrm{Na}, 457.0955$; found, 457.0973. 
(ii-10) Synthesis of Me-OMe (Method I).

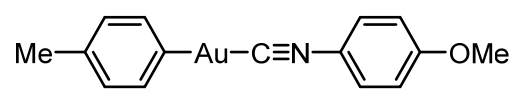

Me-OMe was prepared from 2-OMe $(731.3 \mathrm{mg}, 2.00 \mathrm{mmol}$ ) and 4-methylphenylmagnesium bromide reagent (1-Me) in THF (3.89 ml, $3.00 \mathrm{mmol}, 0.77 \mathrm{M})$ according to Method I. Yield: $67 \%$ (570.2 $\mathrm{mg}, 1.35 \mathrm{mmol}$, pale purple solid).

${ }^{1} \mathrm{H}$ NMR (392 MHz, $\left.\mathrm{CDCl}_{3}, \delta\right): 2.32$ (s, 3H), 3.86 (s, 3H), 6.93-7.10 (m, 2H), 7.09 (d, J= 7.2 Hz, 2H), $7.35(\mathrm{~d}, J=8.2 \mathrm{~Hz}, 2 \mathrm{H}), 7.42-7.47(\mathrm{~m}, 2 \mathrm{H}) .{ }^{13} \mathrm{C} \mathrm{NMR}\left(99 \mathrm{MHz}, \mathrm{CDCl}_{3}, \delta\right): 21.3\left(\mathrm{CH}_{3}\right), 55.7$ $\left(\mathrm{CH}_{3}\right), 115.1(\mathrm{CH}), 117.4(\mathrm{C}), 128.2(\mathrm{CH}), 135.4(\mathrm{C}), 140.0(\mathrm{CH}), 158.9(\mathrm{C}), 159.0-161.0(C), 161.2$ (C). MS-FAB $(m / z)$ : $[\mathrm{M}+\mathrm{Na}]^{+}$calcd for $\mathrm{C}_{15} \mathrm{H}_{14} \mathrm{ONNaAu}$, 444.0639; found, 444.0631 .

(ii-11) Synthesis of Me-Me (Method I).

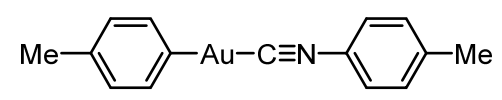

Me-Me was prepared from 2-Me $(701.5 \mathrm{mg}, 2.01 \mathrm{mmol})$ and 4-methylphenylmagnesium bromide reagent (1-Me) in THF $(3.89 \mathrm{ml}, 3.00 \mathrm{mmol}, 0.77 \mathrm{M})$ according to Method I. Yield: 79\% (641.4 mg, $1.83 \mathrm{mmol}$, pale purple solid).

${ }^{1} \mathrm{H}$ NMR (392 MHz, $\mathrm{CDCl}_{3}, \delta$ ): 2.32 (s, 3H), 2.42 (s, 3H), 7.09 (d, J=7.1 Hz, 2H), 7.26-7.29 (m, $2 \mathrm{H}), 7.35$ (d, $J=7.8 \mathrm{~Hz}, 2 \mathrm{H}), 7.40(\mathrm{~d}, J=8.6 \mathrm{~Hz}, 2 \mathrm{H}) .{ }^{13} \mathrm{C} \mathrm{NMR}\left(99 \mathrm{MHz}, \mathrm{CDCl}_{3}, \delta\right): 21.3\left(\mathrm{CH}_{3}\right)$, $21.6\left(\mathrm{CH}_{3}\right), 122.4(\mathrm{C}), 126.4(\mathrm{CH}), 128.2(\mathrm{CH}), 130.4(\mathrm{CH}), 135.4(C), 140.0(\mathrm{CH}), 141.9(C), 158.9$ (C), $161.4(C)$. MS-FAB $(m / z)$ : $[\mathrm{M}+\mathrm{Na}]^{+}$calcd for $\mathrm{C}_{15} \mathrm{H}_{14} \mathrm{NNaAu}, 428.0690$; found, 428.0690 .

(ii-12) Synthesis of Me-H (Method I).

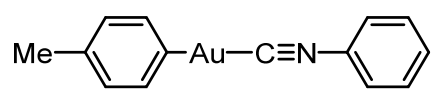

Me-H was prepared from 2-H (335.6 $\mathrm{mg}, 1.00 \mathrm{mmol})$ and 4-methylphenylmagnesium bromide reagent (1-Me) in THF (1.94 ml, $1.49 \mathrm{mmol}, 0.77 \mathrm{M})$ according to Method I. Yield: $70 \%$ (274.8 $\mathrm{mg}$, $0.702 \mathrm{mmol}$, gray solid).

${ }^{1} \mathrm{H}$ NMR (392 MHz, $\left.\mathrm{CDCl}_{3}, \delta\right): 2.32$ (s, 3H), 7.10 (d, $\left.J=7.8 \mathrm{~Hz}, 2 \mathrm{H}\right), 7.36(\mathrm{~d}, J=7.4 \mathrm{~Hz}, 2 \mathrm{H})$, 7.48-7.51 (m, 4H), 7.54-7.59 (m, 1H). $\left.{ }^{13} \mathrm{C} \mathrm{NMR} \mathrm{(100} \mathrm{MHz,} \mathrm{CDCl}_{3}, \delta\right): 21.3\left(\mathrm{CH}_{3}\right), 125.0(C), 126.6$ $(\mathrm{CH}), 128.2(\mathrm{CH}), 129.9(\mathrm{CH}), 131.1(\mathrm{CH}), 135.5(\mathrm{C}), 140.0(\mathrm{CH}), 158.8(\mathrm{C}), 161.5-161.9(\mathrm{~m}, C)$. MS-FAB $(\mathrm{m} / z)$ : $[\mathrm{M}]^{+}$calcd for $\mathrm{C}_{14} \mathrm{H}_{12} \mathrm{NAu}, 391.0635$; found, 391.0627.

(ii-13) Synthesis of Me-Cl (Method I). 


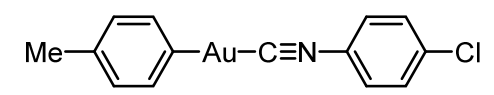

Me-Cl was prepared from 2-Cl $(369.8 \mathrm{mg}, 1.00 \mathrm{mmol})$ and 4-methylphenylmagnesium bromide reagent (1-Me) in THF (3.00 ml, $1.50 \mathrm{mmol}, 0.50 \mathrm{M}$ ) according to Method I. Yield: 79\% (337.0 mg, $0.791 \mathrm{mmol}$, gray solid).

${ }^{1} \mathrm{H}$ NMR (392 MHz, $\left.\mathrm{CDCl}_{3}, \delta\right): 2.32$ (s, 3H), 7.10 (d, $\left.J=7.8 \mathrm{~Hz}, 2 \mathrm{H}\right), 7.34$ (d, $\left.J=7.8 \mathrm{~Hz}, 2 \mathrm{H}\right)$, 7.45-7.50 (m, 4H); MS-FAB (m/z): [M] ${ }^{+}$calcd for $\mathrm{C}_{14} \mathrm{H}_{11} \mathrm{ClNAu}, 425.0246$; found, 425.0252. This compound exhibits poor solubility in common organic solvents (for example, maximum solubility in $\mathrm{CHCl}_{3}$ is $4 \mathrm{mg} / \mathrm{mL}$ ); therefore, ${ }^{13} \mathrm{C}$ NMR spectroscopy can not be measured.

(ii-14) Synthesis of $\mathbf{M e -} \mathbf{C F}_{3}$ (Method I).

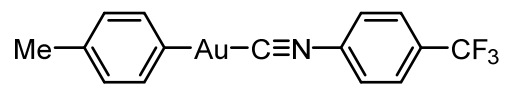

Me- $\mathbf{C F}_{\mathbf{3}}$ was prepared from $\mathbf{2}-\mathbf{C F}_{\mathbf{3}}(811.5 \mathrm{mg}, 2.01 \mathrm{mmol})$ and 4-methylphenylmagnesium bromide reagent (1-Me) in THF $(6.00 \mathrm{ml}, 3.00 \mathrm{mmol}, 0.50 \mathrm{M})$ according to Method I. Yield: $83 \%$ (766.8 $\mathrm{mg}$, $1.67 \mathrm{mmol}$, gray solid).

${ }^{1} \mathrm{H}$ NMR (392 MHz, $\left.\mathrm{CDCl}_{3}, \delta\right): 2.32(\mathrm{~s}, 3 \mathrm{H}), 7.10$ (d, $\left.J=7.4 \mathrm{~Hz}, 2 \mathrm{H}\right), 7.35$ (d, J= 7.8 Hz, 2H), 7.66 $(\mathrm{d}, J=8.2 \mathrm{~Hz}, 2 \mathrm{H}), 7.79(\mathrm{~d}, J=8.6 \mathrm{~Hz}, 2 \mathrm{H})$. MS-FAB $(\mathrm{m} / z):[\mathrm{M}]^{+}$calcd for $\mathrm{C}_{15} \mathrm{H}_{11} \mathrm{AuF}_{3} \mathrm{~N}$, 459.0509; found, 459.0516. This compound exhibits poor solubility in common organic solvents (for example, maximum solubility in $\mathrm{CHCl}_{3}$ is $5 \mathrm{mg} / \mathrm{mL}$ ); therefore, ${ }^{13} \mathrm{C}$ NMR spectroscopy can not be measured.

(ii-15) Synthesis of Me-CN (Method I).

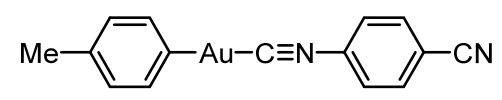

Me-CN was prepared from 2-CN (360.9 $\mathrm{mg}, 1.00 \mathrm{mmol})$ and 4-methylphenylmagnesium bromide reagent (1-Me) in THF $(3.00 \mathrm{ml}, 1.50 \mathrm{mmol}, 0.50 \mathrm{M})$ according to Method I. Yield: 70\% (293.3 mg, $0.704 \mathrm{mmol}$, white solid).

${ }^{1} \mathrm{H}$ NMR (392 MHz, $\mathrm{CDCl}_{3}, \delta$ ): 2.33 (s, 3H), 7.10 (d, J=7.4 Hz, 2H), 7.34 (d, J= 7.8 Hz, 2H), 7.66 $(\mathrm{d}, J=8.6 \mathrm{~Hz}, 2 \mathrm{H}), 7.83(\mathrm{~d}, J=8.6 \mathrm{~Hz}, 2 \mathrm{H})$. MS-FAB $(\mathrm{m} / \mathrm{z}):[\mathrm{M}]^{+}$calcd for $\mathrm{C}_{15} \mathrm{H}_{11} \mathrm{AuN}_{2}, 416.0588$; found, 416.0577. This compound exhibits poor solubility in common organic solvents (for example, maximum solubility in $\mathrm{CHCl}_{3}$ is $1 \mathrm{mg} / \mathrm{mL}$ ); therefore, ${ }^{13} \mathrm{C}$ NMR spectroscopy can not be measured.

(ii-16) Synthesis of Me-NO $\mathrm{NO}_{2}$ (Method I). 


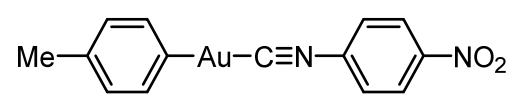

Me-NO $\mathbf{N}_{2}$ was prepared from 2-NO $(380.7 \mathrm{mg}, 1.00 \mathrm{mmol})$ and 4-methylphenylmagnesium bromide reagent (1-Me) in THF (3.00 ml, $1.50 \mathrm{mmol}, 0.50 \mathrm{M})$ according to Method I. Yield: 41\% (179.1 mg, $0.411 \mathrm{mmol}$, pale yellow solid).

${ }^{1} \mathrm{H}$ NMR (392 MHz, $\mathrm{CDCl}_{3}, \delta$ ): 2.33 (s, 3H), 7.10 (d, $\left.J=7.4 \mathrm{~Hz}, 2 \mathrm{H}\right), 7.34$ (d, J=8.2 Hz, 2H), 7.74 $(\mathrm{d}, J=9.4 \mathrm{~Hz}, 2 \mathrm{H}), 8.40(\mathrm{~d}, J=9.0 \mathrm{~Hz}, 2 \mathrm{H})$. MS-ESI $(\mathrm{m} / \mathrm{z}):[\mathrm{M}+\mathrm{Na}]^{+}$calcd for $\mathrm{C}_{14} \mathrm{H}_{11} \mathrm{O}_{2} \mathrm{~N}_{2} \mathrm{AuNa}$, 459.0384; found, 459.0383. This compound exhibits poor solubility in common organic solvents (for example, maximum solubility in $\mathrm{CHCl}_{3}$ is $1 \mathrm{mg} / \mathrm{mL}$ ); therefore, ${ }^{13} \mathrm{C} \mathrm{NMR}$ spectroscopy can not be measured.

(ii-17) Synthesis of $\mathbf{H}-\mathrm{NMe}_{2}$ (Method I).

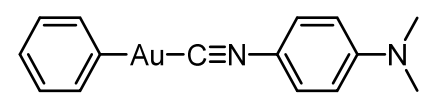

$\mathbf{H}_{-} \mathbf{N M e}_{2}$ was prepared from 2-NMe $(190.0 \mathrm{mg}, 0.502 \mathrm{mmol})$ and phenylmagnesium bromide reagent $(\mathbf{1 - H})$ in THF $(0.830 \mathrm{ml}, 0.747 \mathrm{mmol}, 0.90 \mathrm{M})$ according to Method I. Yield: 67\% (141.3 mg, $0.335 \mathrm{mmol}$, gray solid).

${ }^{1} \mathrm{H}$ NMR (396 MHz, $\left.\mathrm{CDCl}_{3}, \delta\right): 3.04$ (s, 6H), 6.63 (d, $\left.J=8.7 \mathrm{~Hz}, 2 \mathrm{H}\right), 7.06-7.09$ (m, 2H), 7.23-7.26 $(\mathrm{m}, 2 \mathrm{H}), 7.33(\mathrm{~d}, J=9.1 \mathrm{~Hz}, 2 \mathrm{H}), 7.46(\mathrm{~d}, J=7.5 \mathrm{~Hz}, 2 \mathrm{H})$. MS-FAB $(\mathrm{m} / z):[\mathrm{M}]^{+}$calcd for $\mathrm{C}_{15} \mathrm{H}_{15} \mathrm{~N}_{2} \mathrm{Au}$, 420.0901; found, 420.0897. This compound exhibits poor solubility in common organic solvents (for example, maximum solubility in $\mathrm{CHCl}_{3}$ is $1 \mathrm{mg} / \mathrm{mL}$ ); therefore, ${ }^{13} \mathrm{C} \mathrm{NMR}$ spectroscopy can not be measured.

(ii-18) Synthesis of H-OMe (Method II).

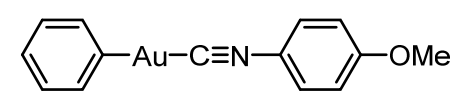

H-OMe was prepared from 2-OMe $(109.8 \mathrm{mg}, 0.300 \mathrm{mmol})$ and organozinc iodide reagent (1-H) in THF (0.44 ml, $0.455 \mathrm{mmol}, 1.035 \mathrm{M}$ ) according to Method II. Yield: 46\% (56.0 mg, $0.138 \mathrm{mmol}$, gray solid).

${ }^{1} \mathrm{H}$ NMR (392 MHz, $\left.\mathrm{CDCl}_{3}, \delta\right): 3.87$ (s, 3H), 6.94-6.98 (m, 2H), 7.06-7.11 (m, 1H), 7.24-7.27 (m, 2H), 7.43-7.46 (m, 4H). ${ }^{13} \mathrm{C}$ NMR (99 MHz, $\left.\mathrm{CDCl}_{3}, \delta\right): 55.8\left(\mathrm{CH}_{3}\right), 115.1(\mathrm{CH}), 117.3(\mathrm{C}), 126.1$ $(\mathrm{CH}), 127.4(\mathrm{CH}), 128.2(\mathrm{CH}), 140.3(\mathrm{CH}), 160.9(\mathrm{C}), 161.2(\mathrm{C}), 162.7(\mathrm{C}) . \mathrm{MS}-\mathrm{FAB}(\mathrm{m} / \mathrm{z}):[\mathrm{M}]^{+}$ calcd for $\mathrm{C}_{14} \mathrm{H}_{12} \mathrm{ONAu}$, 407.0584; found, 407.0569.

(ii-19) Synthesis of H-Me (Method I). 


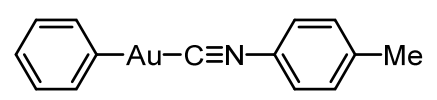

H-Me was prepared from 2-Me $(699.9 \mathrm{mg}, 2.00 \mathrm{mmol})$ and phenylmagnesium bromide reagent (1-H) in THF (3.31 ml, $3.01 \mathrm{mmol}, 0.91 \mathrm{M})$ according to Method I. Yield: 77\% (604.0 mg, 1.54 mmol, white solid).

${ }^{1} \mathrm{H}$ NMR (392 MHz, $\mathrm{CDCl}_{3}, \delta$ ): 2.42 (s, 3H), 7.09 (t, $\left.J=7.5 \mathrm{~Hz}, 1 \mathrm{H}\right), 7.24-7.29$ (m, 4H), 7.40 (d, $J=$ 8.2 Hz, 2H), 7.44-7.46 (m, 2H). ${ }^{13} \mathrm{C} \mathrm{NMR}\left(99 \mathrm{MHz}, \mathrm{CDCl}_{3}, \delta\right): 21.6\left(\mathrm{CH}_{3}\right), 122.3(\mathrm{C}), 126.1(\mathrm{CH})$, $126.4(\mathrm{CH}), 127.4(\mathrm{CH}), 130.5(\mathrm{CH}), 140.3(\mathrm{CH}), 141.9(\mathrm{C}), 160.9-161.3(\mathrm{~m}, C), 162.7(C)$. MS-FAB $(m / z)$ : $[\mathrm{M}]^{+}$calcd for $\mathrm{C}_{14} \mathrm{H}_{12} \mathrm{NAu}, 391.0635$; found, 391.0628 .

(ii-20) Synthesis of $\mathbf{H}-\mathbf{H}$.

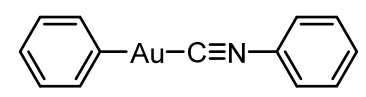

The synthetic procedure of $\mathbf{H}-\mathbf{H}$ was reported previously. ${ }^{\mathrm{S} 7}$

(ii-21) Synthesis of H-Cl (Method II).

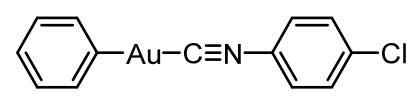

H-Cl was prepared from 2-Cl (111.6 $\mathrm{mg}, 0.302 \mathrm{mmol})$ and organozinc iodide reagent $\mathbf{( 1 - H )}$ in THF (0.44 ml, $0.455 \mathrm{mmol}, 1.035 \mathrm{M})$ according to Method II. Yield: 52\% (71.5 mg, $0.157 \mathrm{mmol}$, pale purple solid).

${ }^{1} \mathrm{H}$ NMR (392 MHz, $\mathrm{CDCl}_{3}, \delta$ ): 7.09 (t, $\left.J=7.5 \mathrm{~Hz}, 1 \mathrm{H}\right), 7.24-7.28(\mathrm{~m}, 2 \mathrm{H}), 7.43-7.50(\mathrm{~m}, 6 \mathrm{H}) .{ }^{13} \mathrm{C}$ NMR (99 MHz, $\left.\mathrm{CDCl}_{3}, \delta\right): 123.4(C), 126.2(\mathrm{CH}), 127.4(\mathrm{CH}), 127.9(\mathrm{CH}), 130.3(\mathrm{CH}), 137.4(C)$, $140.3(\mathrm{CH}), 162.6(\mathrm{C}), 162.7(\mathrm{C})$. MS-FAB $(\mathrm{m} / \mathrm{z})$ : $[\mathrm{M}]^{+}$calcd for $\mathrm{C}_{13} \mathrm{H}_{9} \mathrm{NClAu}, 411.0089$; found, 411.0081 .

(ii-22) Synthesis of $\mathbf{H}-\mathbf{C F}_{\mathbf{3}}$ (Method I).

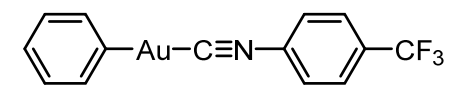

$\mathbf{H}-\mathbf{C F}_{\mathbf{3}}$ was prepared from $\mathbf{2}-\mathbf{C F}_{\mathbf{3}}(1.213 \mathrm{mg}, 3.01 \mathrm{mmol})$ and phenylmagnesium bromide reagent (1-H) in THF (4.97 ml, $4.52 \mathrm{mmol}, 0.91 \mathrm{M}$ ) according to Method I. Yield: 56\% (759.4 mg, 1.71 mmol, white solid).

${ }^{1} \mathrm{H}$ NMR (392 MHz, $\mathrm{CDCl}_{3}, \delta$ ): 7.08-7.11 (m, 1H), 7.24-7.28 (m, 2H), 7.40-7.50 (m, 2H), 7.67 (d, $J$ $=8.7 \mathrm{~Hz}, 2 \mathrm{H}), 7.79(\mathrm{~d}, J=8.7 \mathrm{~Hz}, 2 \mathrm{H}) .{ }^{13} \mathrm{C} \mathrm{NMR}\left(99 \mathrm{MHz}, \mathrm{CDCl}_{3}, \delta\right): 122.9\left(\mathrm{q},{ }^{1} J_{\mathrm{C}-\mathrm{F}}=274 \mathrm{~Hz}\right.$, $\left.C_{\mathrm{F}}\right), 126.2(\mathrm{CH}), 127.1\left(\mathrm{~d},{ }^{3} J_{\mathrm{C}-\mathrm{F}}=3.8 \mathrm{~Hz}, \mathrm{CH}\right), 127.3(\mathrm{CH}), 127.5(\mathrm{CH}), 127.8(\mathrm{C}), 132.9\left(\mathrm{q},{ }^{2} J_{\mathrm{C}-\mathrm{F}}=\right.$ 
$33 \mathrm{~Hz}, C), 140.4(C), 162.6(C), 163.4(C) . \operatorname{MS}-\mathrm{FAB}(\mathrm{m} / \mathrm{z})$ : $[\mathrm{M}]^{+}$calcd for $\mathrm{C}_{14} \mathrm{H}_{9} \mathrm{NF}_{3} \mathrm{Au}, 445.0353$; found, 445.0338 .

(ii-23) Synthesis of H-CN (Method I).

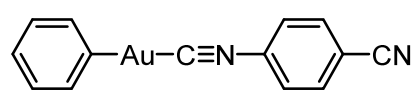

H-CN was prepared from 2-CN (180.7 $\mathrm{mg}, 0.500 \mathrm{mmol})$ and phenylmagnesium bromide reagent (1-H) in THF $(0.830 \mathrm{ml}, 0.750 \mathrm{mmol}, 0.90 \mathrm{M})$ according to Method I. Yield: 43\% (86.2 mg, 0.214 mmol, gray solid).

${ }^{1} \mathrm{H}$ NMR (392 MHz, $\mathrm{CDCl}_{3}, \delta$ ): 7.08-7.12 (m, 1H), 7.25-7.28 (m, 2H), 7.43-7.45 (m, 2H), 7.65 (dd, $J=2.0,8.6 \mathrm{~Hz}, 2 \mathrm{H}), 7.83(\mathrm{~d}, J=8.2 \mathrm{~Hz}, 2 \mathrm{H})$. MS-FAB $(\mathrm{m} / \mathrm{z})$ : $[\mathrm{M}]^{+}$calcd for $\mathrm{C}_{14} \mathrm{H}_{9} \mathrm{~N}_{2} \mathrm{Au}, 402.0431$; found, 402.0431. This compound exhibits poor solubility in common organic solvents (for example, maximum solubility in $\mathrm{CHCl}_{3}$ is $5 \mathrm{mg} / \mathrm{mL}$ ); therefore, ${ }^{13} \mathrm{C}$ NMR spectroscopy can not be measured.

(ii-24) Synthesis of $\mathbf{H}-\mathrm{NO}_{2}$ (Method I).

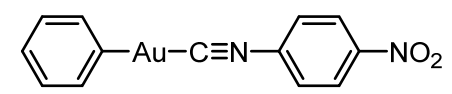

H-NO $\mathbf{2}_{2}$ was prepared from 2-NO $(190.7 \mathrm{mg}, 0.501 \mathrm{mmol})$ and phenylmagnesium bromide reagent (1-H) in THF $(0.830 \mathrm{ml}, 0.750 \mathrm{mmol}, 0.90 \mathrm{M})$ according to Method I. Yield: 76\% (161.3 mg, 0.382 mmol, gray solid).

${ }^{1} \mathrm{H}$ NMR (392 MHz, $\left.\mathrm{CDCl}_{3}, \delta\right): 7.08-7.13$ (m, 1H), 7.25-7.29 (m, 2H), 7.43-7.45 (m, 2H), 7.73$7.76(\mathrm{~m}, 2 \mathrm{H}), 8.39-8.42(\mathrm{~m}, 2 \mathrm{H})$. MS-FAB $(\mathrm{m} / \mathrm{z})$ : $[\mathrm{M}]^{+}$calcd for $\mathrm{C}_{13} \mathrm{H}_{9} \mathrm{O}_{2} \mathrm{~N}_{2} \mathrm{Au}, 422.0330$; found, 422.0320. This compound exhibits poor solubility in common organic solvents (for example, maximum solubility in $\mathrm{CHCl}_{3}$ is $2 \mathrm{mg} / \mathrm{mL}$ ); therefore, ${ }^{13} \mathrm{C}$ NMR spectroscopy can not be measured.

(ii-25) Synthesis of Cl-NMe 2 (Method I).

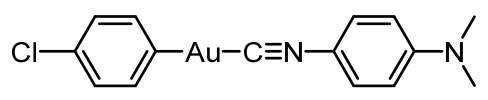

Cl-NMe 2 was prepared from 2-NMe $(1.116 \mathrm{~g}, 2.96 \mathrm{mmol})$ and 4-chlorophenylmagnesium bromide reagent (1-CI) in THF $(6.72 \mathrm{ml}, 4.50 \mathrm{mmol}, 0.67 \mathrm{M})$ according to Method I. Yield: $84 \%$ (1.144 g, $2.51 \mathrm{mmol}$, white solid).

${ }^{1} \mathrm{H}$ NMR (392 MHz, $\left.\mathrm{CDCl}_{3}, \delta\right): 3.05(\mathrm{~s}, 6 \mathrm{H}), 6.61-6.65(\mathrm{~m}, 2 \mathrm{H}), 7.22(\mathrm{~d}, J=8.6 \mathrm{~Hz}, 2 \mathrm{H}), 7.33(\mathrm{~d}, J$ $=8.6 \mathrm{~Hz}, 2 \mathrm{H}), 7.39(\mathrm{~d}, J=7.8 \mathrm{~Hz}, 2 \mathrm{H}) .{ }^{13} \mathrm{C} \mathrm{NMR}\left(99 \mathrm{MHz}, \mathrm{CDCl}_{3}, \delta\right): 40.1\left(\mathrm{CH}_{3}\right), 111.7(\mathrm{CH})$, $111.8(C), 127.2(C H), 127.7(C H), 131.6(C), 141.0(C H), 151.2(C), 159.9(C), 160.8(C)$. MS-FAB $(m / z):[\mathrm{M}]^{+}$calcd for $\mathrm{C}_{15} \mathrm{H}_{14} \mathrm{~N}_{2} \mathrm{ClAu}, 454.0511$; found, 454.0512 . 
(ii-26) Synthesis of Cl-OMe (Method I).

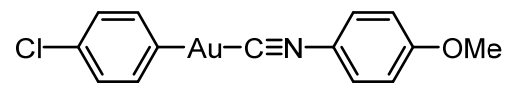

Cl-OMe was prepared from 2-OMe $(182.9 \mathrm{mg}, 0.500 \mathrm{mmol})$ and 4-chlorophenylmagnesium bromide reagent (1-Cl) in THF $(0.789 \mathrm{ml}, 0.750 \mathrm{mmol}, 0.95 \mathrm{M})$ according to Method I. Yield: $59 \%$ (129.9 mg, $0.294 \mathrm{mmol}$, gray solid).

${ }^{1} \mathrm{H}$ NMR (392 MHz, $\left.\mathrm{CDCl}_{3}, \delta\right): 3.87$ (s, 3H), 6.94-6.98 (m, 2H), 7.23 (d, J=8.2 Hz, 2H), 7.39 (d, $J$ $=7.8 \mathrm{~Hz}, 2 \mathrm{H}), 7.45(\mathrm{~d}, J=8.6 \mathrm{~Hz}, 2 \mathrm{H}) .{ }^{13} \mathrm{C} \mathrm{NMR}\left(99 \mathrm{MHz}, \mathrm{CDCl}_{3}, \delta\right): 55.7\left(\mathrm{CH}_{3}\right), 115.1(\mathrm{CH})$, 117.2 (C), $127.2(\mathrm{CH}), 128.2(\mathrm{CH}), 131.6(C), 141.1(\mathrm{CH}), 160.1(C), 160.7(C), 161.3(C)$. MS-FAB $(\mathrm{m} / \mathrm{z}):[\mathrm{M}]^{+}$calcd for $\mathrm{C}_{14} \mathrm{H}_{11} \mathrm{ONClAu}, 441.0195$; found, 441.0205 .

(ii-27) Synthesis of Cl-Me (Method I).

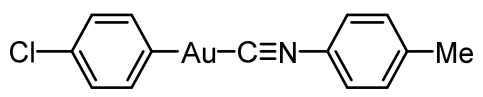

Cl-Me was prepared from 2-Me $(175.4 \mathrm{mg}, 0.500 \mathrm{mmol})$ and 4-chlorophenylmagnesium bromide reagent (1-Cl) in THF $(0.789 \mathrm{ml}, 0.750 \mathrm{mmol}, 0.95 \mathrm{M})$ according to Method I. Yield: $64 \%$ (137.6 mg, $0.323 \mathrm{mmol}$, white solid).

${ }^{1} \mathrm{H}$ NMR (392 MHz, $\left.\mathrm{CDCl}_{3}, \delta\right): 2.43(\mathrm{~s}, 3 \mathrm{H}), 7.23$ (d, $\left.J=8.2 \mathrm{~Hz}, 2 \mathrm{H}\right), 7.29$ (d, $\left.J=8.6 \mathrm{~Hz}, 2 \mathrm{H}\right)$, 7.38-7.41 (m, 4H). MS-FAB $(\mathrm{m} / \mathrm{z})$ : $[\mathrm{M}]^{+}$calcd for $\mathrm{C}_{14} \mathrm{H}_{11} \mathrm{NClAu}, 425.0246$; found, 425.0254. This compound exhibits poor solubility in common organic solvents (for example, maximum solubility in $\mathrm{CHCl}_{3}$ is $1 \mathrm{mg} / \mathrm{mL}$ ); therefore, ${ }^{13} \mathrm{C}$ NMR spectroscopy can not be measured.

(ii-28) Synthesis of Cl-H (Method I).

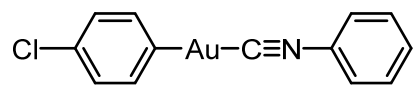

Cl-H was prepared from 2-H (168.3 $\mathrm{mg}, 0.500 \mathrm{mmol})$ and 4-chlorophenylmagnesium bromide reagent $(\mathbf{1 - C l})$ in THF $(0.789 \mathrm{ml}, 0.750 \mathrm{mmol}, 0.97 \mathrm{M})$ according to Method I. Yield: 92\% (189.9 mg, $0.461 \mathrm{mmol}$, white solid).

${ }^{1} \mathrm{H}$ NMR (392 MHz, $\left.\mathrm{CDCl}_{3}, \delta\right): 7.21-7.25$ (m, 2H), 7.36-7.41 (m, 2H), 7.49-7.61 (m, 5H). ${ }^{13} \mathrm{C}$ NMR (99 MHz, $\left.\mathrm{CDCl}_{3}, \delta\right): 124.9(C), 126.7(\mathrm{CH}), 127.2(\mathrm{CH}), 129.9(\mathrm{CH}), 131.2(\mathrm{CH}), 131.8(C), 141.1$ $(C H), 160.6(C), 160.9(C)$. MS-FAB $(m / z)$ : $[\mathrm{M}]^{+}$calcd for $\mathrm{C}_{13} \mathrm{H}_{9} \mathrm{NClAu}, 411.0089$; found, 411.0083 .

(ii-29) Synthesis of Cl-Cl (Method I). 


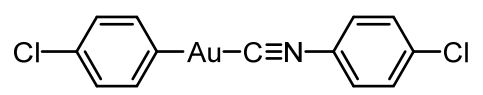

Cl-Cl was prepared from 2-Cl (1.110 g, $3.00 \mathrm{mmol})$ and 4-chlorophenylmagnesium bromide reagent (1-Cl) in THF (6.72 ml, $4.50 \mathrm{mmol}, 0.67 \mathrm{M})$ according to Method I. Yield: 74\% (996.4 mg, 2.51 mmol, pale purple solid).

${ }^{1} \mathrm{H}$ NMR (392 MHz, $\mathrm{CDCl}_{3}, \delta$ ): 7.23 (d, $\left.J=8.2 \mathrm{~Hz}, 2 \mathrm{H}\right), 7.38$ (d, $\left.J=8.2 \mathrm{~Hz}, 2 \mathrm{H}\right), 7.46-7.51$ (m, 4H). MS-ESI $(\mathrm{m} / \mathrm{z})$; $[\mathrm{M}+\mathrm{Na}]^{+}$calcd for $\mathrm{C}_{13} \mathrm{H}_{8} \mathrm{AuCl}_{2} \mathrm{NNa}$, 467.9597; found, 467.9605. This compound exhibits poor solubility in common organic solvents (for example, maximum solubility in $\mathrm{CHCl}_{3}$ is $0.7 \mathrm{mg} / \mathrm{mL}$ ); therefore, ${ }^{13} \mathrm{C}$ NMR spectroscopy can not be measured.

(ii-30) Synthesis of $\mathbf{C l}-\mathbf{C F}_{\mathbf{3}}$ (Method I).

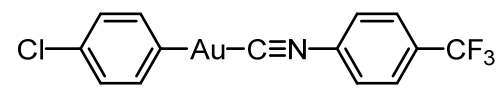

Cl-CF $\mathbf{3}$ was prepared from $\mathbf{2}-\mathbf{C F}_{\mathbf{3}}(1.212 \mathrm{~g}, 3.00 \mathrm{mmol})$ and 4-chlorophenylmagnesium bromide reagent (1-CI) in THF $(6.72 \mathrm{ml}, 4.50 \mathrm{mmol}, 0.67 \mathrm{M})$ according to Method I. Yield: $66 \%(953.6 \mathrm{mg}$, $1.99 \mathrm{mmol}$, gray solid).

${ }^{1} \mathrm{H}$ NMR (396 MHz, $\left.\mathrm{CDCl}_{3}, \delta\right): 7.24(\mathrm{~d}, J=8.7 \mathrm{~Hz}, 2 \mathrm{H}), 7.38(\mathrm{~d}, J=8.7 \mathrm{~Hz}, 2 \mathrm{H}), 7.67$ (d, $J=8.3 \mathrm{~Hz}$, $2 \mathrm{H}), 7.81(\mathrm{~d}, J=8.3 \mathrm{~Hz}, 2 \mathrm{H})$. MS-FAB $(\mathrm{m} / \mathrm{z})$ : $[\mathrm{M}]^{+}$calcd for $\mathrm{C}_{14} \mathrm{H}_{8} \mathrm{NClF}_{3} \mathrm{Au}, 478.9963$; found, 478.9966. This compound exhibits poor solubility in common organic solvents (for example, maximum solubility in $\mathrm{CHCl}_{3}$ is $4 \mathrm{mg} / \mathrm{mL}$ ); therefore, ${ }^{13} \mathrm{C}$ NMR spectroscopy can not be measured.

(ii-31) Synthesis of Cl-CN (Method I).

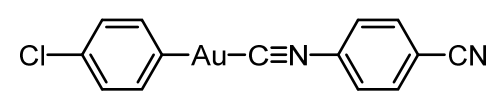

Cl-CN was prepared from 2-CN (1.084 g, $3.01 \mathrm{mmol})$ and 4-chlorophenylmagnesium bromide reagent (1-Cl) in THF $(6.00 \mathrm{ml}, 4.50 \mathrm{mmol}, 0.75 \mathrm{M})$ according to Method I. Yield: 59\% (779.4 mg, $1.79 \mathrm{mmol}$, white solid).

${ }^{1} \mathrm{H}$ NMR (392 MHz, $\left.\mathrm{CDCl}_{3}, \delta\right): 7.22-7.26(\mathrm{~m}, 2 \mathrm{H}), 7.37$ (d, $\left.J=8.3 \mathrm{~Hz}, 2 \mathrm{H}\right), 7.67-7.70(\mathrm{~m}, 2 \mathrm{H})$, 7.83-7.86 (m, 2H). MS-ESI $(m / z)$; [M+Na $]^{+}$calcd for $\mathrm{C}_{14} \mathrm{H}_{8} \mathrm{AuClN}_{2} \mathrm{Na}, 458.9939$; found, 458.9933 . This compound exhibits poor solubility in common organic solvents (for example, maximum solubility in $\mathrm{CHCl}_{3}$ is $0.3 \mathrm{mg} / \mathrm{mL}$ ); therefore, ${ }^{13} \mathrm{C}$ NMR spectroscopy can not be measured.

(ii-32) Synthesis of Cl-NO $($ Method I).

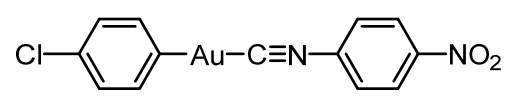


Cl-NO ${ }_{2}$ was prepared from 2-NO $\mathbf{2}(762.3 \mathrm{mg}, 2.00 \mathrm{mmol})$ and 4-chlorophenylmagnesium bromide reagent (1-Cl) in THF $(4.00 \mathrm{ml}, 3.00 \mathrm{mmol}, 0.75 \mathrm{M})$ according to Method I. Yield: $29 \%$ (273.9 $\mathrm{mg}$, $0.600 \mathrm{mmol}$, yellow solid).

${ }^{1} \mathrm{H}$ NMR (392 MHz, $\left.\mathrm{CDCl}_{3}, \delta\right):$ 7.22-7.26 (m, 2H), 7.36-7.39 (m, 2H), 7.74-7.77 (m, 2H), 8.39$8.43(\mathrm{~m}, 2 \mathrm{H})$. This compound exhibits poor solubility in common organic solvents (for example, maximum solubility in $\mathrm{CHCl}_{3}$ is $0.2 \mathrm{mg} / \mathrm{mL}$ ); therefore, ${ }^{13} \mathrm{C} \mathrm{NMR}$ spectroscopy can not be measured.

(ii-33) Synthesis of $\mathbf{C F}_{\mathbf{3}}-\mathbf{N M e}_{2}$ (Method II).

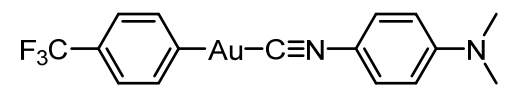

See the general procedure for Method II.

(ii-34) Synthesis of $\mathbf{C F}_{\mathbf{3}}-\mathbf{O M e}$ (Method II).

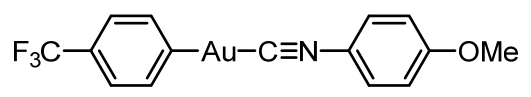

$\mathbf{C F}_{\mathbf{3}}-\mathbf{O M e}$ was prepared from 2-OMe $(1.111 \mathrm{~g}, 3.04 \mathrm{mmol})$ and organozinc iodide reagent $\left(\mathbf{1}-\mathbf{C F}_{\mathbf{3}}\right)$ in THF (4.60 ml, $4.50 \mathrm{mmol}, 0.98 \mathrm{M}$ ) according to Method II. Yield: 79\% (1.126 g, $2.37 \mathrm{mmol}$, pale purple solid).

${ }^{1} \mathrm{H}$ NMR (401 MHz, $\left.\mathrm{CDCl}_{3}, \delta\right): 3.87$ (s, 3H), 6.96 (d, $\left.J=9.2 \mathrm{~Hz}, 2 \mathrm{H}\right), 7.44-7.47$ (m, 4H), 7.56 (d, $J$ $=8.4 \mathrm{~Hz}, 2 \mathrm{H}) .{ }^{13} \mathrm{C}$ NMR $\left(99 \mathrm{MHz}, \mathrm{CDCl}_{3}, \delta\right): 55.7\left(\mathrm{CH}_{3}\right), 115.1(\mathrm{CH}), 117.1(\mathrm{C}), 123.3\left(\mathrm{~d},{ }^{3} J_{\mathrm{C}-\mathrm{F}}=\right.$ $3.8 \mathrm{~Hz}, C \mathrm{H}), 124.7$ (q, $\left.{ }^{1} J_{\mathrm{C}-\mathrm{F}}=273 \mathrm{~Hz}, C \mathrm{~F}_{3}\right), 127.4$ (q, $\left.{ }^{2} J_{\mathrm{C}-\mathrm{F}}=32 \mathrm{~Hz}, C\right), 128.2(\mathrm{CH}), 140.3(C \mathrm{H})$, $159.6(C), 161.3(C), 167.9(C)$. MS-FAB $(m / z):[\mathrm{M}+\mathrm{Na}]^{+}$calcd for $\mathrm{C}_{15} \mathrm{H}_{11} \mathrm{ONF}_{3} \mathrm{NaAu}, 498.0356$; found, 498.0352 .

(ii-35) Synthesis of $\mathbf{C F}_{3}$-Me (Method II).

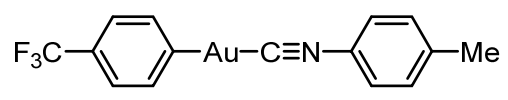

$\mathbf{C F}_{\mathbf{3}}$-Me was prepared from 2-Me $(1.048 \mathrm{~g}, 3.00 \mathrm{mmol})$ and organozinc iodide reagent $\left(\mathbf{1}-\mathbf{C F}_{\mathbf{3}}\right)$ in THF (5.17 ml, $4.50 \mathrm{mmol}, 0.87 \mathrm{M})$ according to Method II. Yield: 78\% (1.086 g, $2.37 \mathrm{mmol}$, pale purple solid).

${ }^{1} \mathrm{H}$ NMR (401 MHz, $\left.\mathrm{CDCl}_{3}, \delta\right): 2.43$ (s, 3H), 7.26-7.30 (m, 2H), $7.41(\mathrm{~d}, J=8.4 \mathrm{~Hz}, 2 \mathrm{H}), 7.47$ (d, $J$ $=7.2 \mathrm{~Hz}, 2 \mathrm{H}), 7.55(\mathrm{~d}, J=7.6 \mathrm{~Hz}, 2 \mathrm{H}) .{ }^{13} \mathrm{C} \mathrm{NMR}\left(99 \mathrm{MHz} \mathrm{CDCl}_{3}, \delta\right): 21.6\left(\mathrm{CH}_{3}\right), 121.9-122.2(\mathrm{~m}$, C), $123.3\left(\mathrm{~d},{ }^{3} J_{\mathrm{C}-\mathrm{F}}=3.8 \mathrm{~Hz} C \mathrm{H}\right), 124.7\left(\mathrm{q},{ }^{1} J_{\mathrm{C}-\mathrm{F}}=273 \mathrm{~Hz}, C \mathrm{~F}_{3}\right), 126.4(C), 127.5\left(\mathrm{q},{ }^{2} J_{\mathrm{C}-\mathrm{F}}=32 \mathrm{~Hz}\right.$, C),130.5 (CH), $140.2(\mathrm{CH}), 142.2(\mathrm{CH}), 159.8-160.2(\mathrm{~m}, \mathrm{C}), 167.7(\mathrm{C}) . \mathrm{MS}-\mathrm{FAB}(\mathrm{m} / \mathrm{z}):[\mathrm{M}]^{+}$calcd 
for $\mathrm{C}_{15} \mathrm{H}_{11} \mathrm{NF}_{3} \mathrm{Au}, 459.0509$; found, 459.0502 .

(ii-36) Synthesis of $\mathbf{C F}_{\mathbf{3}}-\mathbf{H}$ (Method II).

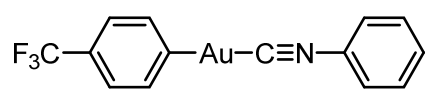

$\mathbf{C F}_{\mathbf{3}}-\mathbf{H}$ was prepared from 2-H (1.006 g, $\left.3.00 \mathrm{mmol}\right)$ and organozinc iodide reagent (1-CF $)$ in THF (4.59 ml, $4.50 \mathrm{mmol}, 0.98 \mathrm{M})$ according to Method II. Yield: 72\% (973.3 mg, $2.19 \mathrm{mmol}$, pale purple solid).

${ }^{1} \mathrm{H}$ NMR (392 MHz, $\left.\mathrm{CDCl}_{3}, \delta\right): 7.47$ (d, $\left.J=7.6 \mathrm{~Hz}, 2 \mathrm{H}\right), 7.51-7.61$ (m, 7H). ${ }^{13} \mathrm{C}$ NMR (99 MHz, $\left.\mathrm{CDCl}_{3}, \delta\right): 123.3\left(\mathrm{~d},{ }^{3} J_{\mathrm{C}-\mathrm{F}}=3.8 \mathrm{~Hz} C \mathrm{H}\right), 124.7\left(\mathrm{q},{ }^{1} J_{\mathrm{C}-\mathrm{F}}=273 \mathrm{~Hz}, C \mathrm{~F}_{3}\right), 124.7(C), 126.6(C \mathrm{H})$, $127.4\left(\mathrm{q},{ }^{2} J_{\mathrm{C}-\mathrm{F}}=32 \mathrm{~Hz}, C\right), 129.8(C \mathrm{H}), 131.2(C \mathrm{H}), 140.4(C), 159.9-160.4(\mathrm{~m}, C), 167.9(C)$. MS-FAB (m/z): $[\mathrm{M}]^{+}$calcd for $\mathrm{C}_{14} \mathrm{H}_{9} \mathrm{NF}_{3} \mathrm{Au}, 445.0353$; found, 445.0353 .

(ii-37) Synthesis of $\mathbf{C F}_{\mathbf{3}}-\mathbf{C l}$ (Method II).

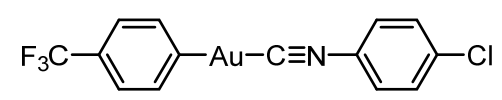

$\mathbf{C F}_{\mathbf{3}}$-Cl was prepared from 2-Cl (1.112 g, $\left.3.01 \mathrm{mmol}\right)$ and organozinc iodide reagent (1-CF $\left.\mathbf{3}\right)$ in THF (4.59 ml, $4.50 \mathrm{mmol}, 0.98 \mathrm{M}$ ) according to Method II. Yield: $79 \%$ (1.149 mg, $2.40 \mathrm{mmol}$, pale purple solid).

${ }^{1} \mathrm{H}$ NMR (392 MHz, $\left.\mathrm{CDCl}_{3}, \delta\right): 7.42-7.50(\mathrm{~m}, 6 \mathrm{H}), 7.56(\mathrm{~d}, J=7.4 \mathrm{~Hz}, 2 \mathrm{H}) .{ }^{13} \mathrm{C} \mathrm{NMR}(99 \mathrm{MHz}$, $\mathrm{CDCl}_{3}, \delta$ ): $123.1(C), 123.3-123.4(\mathrm{~m}, C \mathrm{H}), 124.6\left(\mathrm{q},{ }^{1} J_{\mathrm{C}-\mathrm{F}}=273 \mathrm{~Hz}, C \mathrm{~F}_{3}\right), 127.7$ (q, ${ }^{2} J_{\mathrm{C}-\mathrm{F}}=32 \mathrm{~Hz}$, C), $127.9(\mathrm{CH}), 130.4(\mathrm{CH}), 137.8(\mathrm{C}), 140.2(\mathrm{CH}), 161.7(\mathrm{C}), 167.4(\mathrm{C})$. MS-FAB $(\mathrm{m} / \mathrm{z}):[\mathrm{M}]^{+}$calcd for $\mathrm{C}_{14} \mathrm{H}_{8} \mathrm{NClF}_{3} \mathrm{Au}, 478.9963$; found, 478.9955.

(ii-38) Synthesis of $\mathbf{C F}_{\mathbf{3}}-\mathbf{C F}_{\mathbf{3}}$ (Method II).

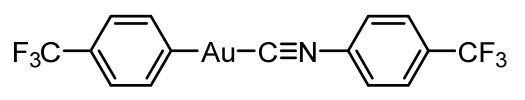

$\mathbf{C F}_{\mathbf{3}}-\mathbf{C F}_{\mathbf{3}}$ was prepared from $\mathbf{2}-\mathbf{C F}_{\mathbf{3}}(1.216 \mathrm{~g}, 3.01 \mathrm{mmol})$ and organozinc iodide reagent (1-CF $\left.\mathbf{3}\right)$ in THF (4.59 ml, $4.50 \mathrm{mmol}, 0.98 \mathrm{M}$ ) according to Method II. Yield: 51\% (795.7 mg, $1.55 \mathrm{mmol}$, gray solid).

${ }^{1} \mathrm{H}$ NMR $\left(392 \mathrm{MHz}, \mathrm{CDCl}_{3}, \delta\right): 7.47(\mathrm{~d}, J=8.2 \mathrm{~Hz}, 2 \mathrm{H}), 7.56(\mathrm{~d}, J=7.4 \mathrm{~Hz}, 2 \mathrm{H}), 7.66(\mathrm{~d}, J=8.6 \mathrm{~Hz}$, $2 \mathrm{H}), 7.80(\mathrm{~d}, J=8.2 \mathrm{~Hz}, 2 \mathrm{H}) .{ }^{13} \mathrm{C} \mathrm{NMR}\left(99 \mathrm{MHz} \mathrm{CDCl}_{3}, \delta\right): 122.9$ (q, $\left.{ }^{1} J_{\mathrm{C}-\mathrm{F}}=274 \mathrm{~Hz}, C \mathrm{~F}_{3}\right), 124.7$ $\left(\mathrm{q},{ }^{1} J_{\mathrm{C}-\mathrm{F}}=273 \mathrm{~Hz}, C \mathrm{~F}_{3}\right), 123.4-123.5(\mathrm{~m}, C \mathrm{H}), 127.3(\mathrm{CH}), 127.7(C), 127.7\left(\mathrm{q},{ }^{2} J_{\mathrm{C}-\mathrm{F}}=32 \mathrm{~Hz}, C\right.$ ), $133.2\left(\mathrm{q},{ }^{2} J_{\mathrm{C}-\mathrm{F}}=34 \mathrm{~Hz}, C\right), 140.3(\mathrm{CH}), 162.4(C), 167.6(C)$. MS-FAB $(\mathrm{m} / \mathrm{z}):[\mathrm{M}+\mathrm{H}]^{+}$calcd for $\mathrm{C}_{15} \mathrm{H}_{8} \mathrm{NF}_{6} \mathrm{Au}, 513.0227$; found, 513.0228. 
(ii-39) Synthesis of $\mathbf{C F}_{3}-\mathbf{C N}$ (Method II).

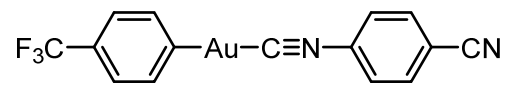

$\mathbf{C F}_{\mathbf{3}} \mathbf{-} \mathbf{C N}$ was prepared from $\mathbf{2}-\mathbf{C N}(360.9 \mathrm{~g}, 1.00 \mathrm{mmol})$ and organozinc iodide reagent $\left(\mathbf{1}-\mathbf{C F}_{\mathbf{3}}\right)$ in THF (2.63 ml, $1.50 \mathrm{mmol}, 0.57 \mathrm{M}$ ) according to Method II. Yield: 68\% (320.5 mg, $0.682 \mathrm{mmol}$, yellow solid).

${ }^{1} \mathrm{H}$ NMR (392 MHz, $\left.\mathrm{CDCl}_{3}, \delta\right): 7.47(\mathrm{~d}, J=8.2 \mathrm{~Hz}, 2 \mathrm{H}), 7.56(\mathrm{~d}, J=8.2 \mathrm{~Hz}, 2 \mathrm{H}), 7.61(\mathrm{~d}, J=8.2 \mathrm{~Hz}$, $2 \mathrm{H}), 7.83(\mathrm{~d}, J=8.6 \mathrm{~Hz}, 2 \mathrm{H})$. MS-FAB $(\mathrm{m} / \mathrm{z})$ : $[\mathrm{M}]^{+}$calcd for $\mathrm{C}_{15} \mathrm{H}_{8} \mathrm{~N}_{2} \mathrm{~F}_{3} \mathrm{Au}, 470.0305$; found, 470.0310. Anal. Calcd for $\mathrm{C}_{15} \mathrm{H}_{8} \mathrm{AuF}_{3} \mathrm{~N}_{2}$ : C, 38.32; H, 1.71; N, 5.96. Found: C, 38.09; H, 1.54; N, 5.79. This compound exhibits low solubility in common organic solvents (for example, maximum solubility in $\mathrm{CHCl}_{3}$ is $\left.9 \mathrm{mg} / \mathrm{mL}\right) .{ }^{13} \mathrm{C}$ NMR spectrum of $\mathbf{C F}_{\mathbf{3}}-\mathbf{C N}$ was recorded for $12 \mathrm{~h}$ by using its saturated $\mathrm{CDCl}_{3}$ solution; however, we cannot detect all the expected signals of this compound.

(ii-40) Synthesis of $\mathbf{C F}_{3}-\mathbf{N O}_{2}$ (Method II).

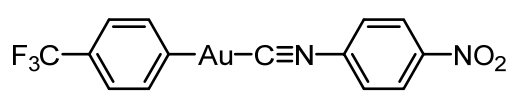

$\mathbf{C F}_{\mathbf{3}}-\mathbf{N O}_{\mathbf{2}}$ was prepared from $\mathbf{2}-\mathbf{N O}_{\mathbf{2}}(1.145 \mathrm{~g}, 3.00 \mathrm{mmol})$ and organozinc iodide reagent (1-CF $\left.\mathbf{3}\right)$ in THF (4.59 ml, $4.50 \mathrm{mmol}, 0.98 \mathrm{M}$ ) according to Method II. Yield: 75\% (1.108 g, $2.26 \mathrm{mmol}$, brown solid).

${ }^{1} \mathrm{H}$ NMR (392 MHz, $\left.\mathrm{CDCl}_{3}, \delta\right): 7.48(\mathrm{~d}, J=8.2 \mathrm{~Hz}, 2 \mathrm{H}), 7.57(\mathrm{~d}, J=7.4 \mathrm{~Hz}, 2 \mathrm{H}), 7.73-7.76$ (m, $2 \mathrm{H}), 8.40-8.43$ (m, 2H). MS-FAB (m/z): [M] $]^{+}$calcd for $\mathrm{C}_{14} \mathrm{H}_{8} \mathrm{O}_{2} \mathrm{~N}_{2} \mathrm{~F}_{3} \mathrm{Au}, 490.0203$; found, 490.0205 . This compound exhibits poor solubility in common organic solvents (for example, maximum solubility in $\mathrm{CHCl}_{3}$ is $1 \mathrm{mg} / \mathrm{mL}$ ); therefore, ${ }^{13} \mathrm{C}$ NMR spectroscopy can not be measured.

(ii-41) Synthesis of $\mathbf{C N}-\mathbf{N M e}_{2}$ (Method II).

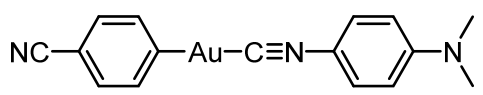

$\mathbf{C N}^{-N M e}{ }_{2}$ was prepared from 2-NMe $2(1.138 \mathrm{~g}, 3.00 \mathrm{mmol})$ and organozinc iodide reagent (1-CN) in THF (4.60 ml, $4.50 \mathrm{mmol}, 0.98 \mathrm{M}$ ) according to Method II. Yield: 60\% (812.3 mg, $1.82 \mathrm{mmol}$, white solid).

${ }^{1} \mathrm{H}$ NMR (392 MHz, $\left.\mathrm{CDCl}_{3}, \delta\right): 3.05$ (s, 6H), 6.61-6.65 (m, 2H), 7.33 (d, J=9.0 Hz, 2H), 7.47 (d, $J$ $=8.2 \mathrm{~Hz}, 2 \mathrm{H}), 7.54(\mathrm{~d}, J=8.2 \mathrm{~Hz}, 2 \mathrm{H}) . \operatorname{MS}-\mathrm{FAB}(\mathrm{m} / \mathrm{z}):[\mathrm{M}+\mathrm{Na}]^{+}$calcd for $\mathrm{C}_{16} \mathrm{H}_{14} \mathrm{~N}_{3} \mathrm{AuNa}$, 468.0751; found, 468.0751. This compound exhibits poor solubility in common organic solvents (for example, maximum solubility in $\mathrm{CHCl}_{3}$ is $6 \mathrm{mg} / \mathrm{mL}$ ); therefore, ${ }^{13} \mathrm{C}$ NMR spectroscopy can not be 
measured.

(ii-42) Synthesis of CN-OMe (Method II).

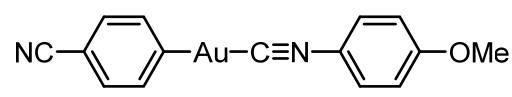

CN-OMe was prepared from 2-OMe (182.4 mg, $0.499 \mathrm{mmol})$ and organozinc iodide reagent (1-CN) in THF (0.815 ml, $0.750 \mathrm{mmol}, 0.92 \mathrm{M}$ ) according to Method II. Yield: 85\% (185.3 mg, 0.429 mmol, pale purple solid).

${ }^{1} \mathrm{H}$ NMR (392 MHz, $\mathrm{CDCl}_{3}, \delta$ ): 3.88 (s, 3H), 6.95-6.99 (m, 2H), 7.45-7.48 (m, 4H), $7.54(\mathrm{~d}, J=8.2$ $\mathrm{Hz}, 2 \mathrm{H}) .{ }^{13} \mathrm{C}$ NMR (99 MHz, $\left.\mathrm{CDCl}_{3}, \delta\right): 55.8\left(\mathrm{CH}_{3}\right), 108.9(C), 115.2(C \mathrm{H}), 117.0(C), 120.0(C)$, $128.3(\mathrm{CH}), 130.0(\mathrm{CH}), 140.5(\mathrm{CH}), 159.2-159.7(\mathrm{~m}, C), 161.5(C), 170.3(C) . \mathrm{MS}-\mathrm{FAB}(\mathrm{m} / \mathrm{z}):[\mathrm{M}]^{+}$ calcd for $\mathrm{C}_{15} \mathrm{H}_{11} \mathrm{ON}_{2} \mathrm{Au}, 432.0537$; found, 432.0541 .

(ii-43) Synthesis of CN-Me (Method II).

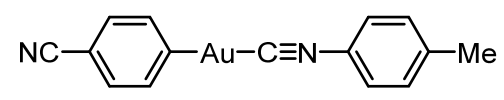

CN-Me was prepared from 2-Me $(1.052 \mathrm{~g}, 3.01 \mathrm{mmol})$ and organozinc iodide reagent $(\mathbf{1 - C N})$ in THF (4.59 ml, $4.50 \mathrm{mmol}, 0.98 \mathrm{M})$ according to Method II. Yield: 90\% (1.127 g, $2.71 \mathrm{mmol}$, pale purple solid).

${ }^{1} \mathrm{H}$ NMR (392 MHz, $\left.\mathrm{CDCl}_{3}, \delta\right): 2.44$ (s, 3H), 7.30 (d, $\left.J=8.2 \mathrm{~Hz}, 2 \mathrm{H}\right), 7.41(\mathrm{~d}, J=8.6 \mathrm{~Hz}, 2 \mathrm{H})$, 7.40-7.50 (m, 2H), 7.51-7.56 (m, 2H). MS-FAB (m/z): [M] $]^{+}$calcd for $\mathrm{C}_{15} \mathrm{H}_{11} \mathrm{~N}_{2} \mathrm{Au}, 416.0588$; found, 416.0589. This compound exhibits poor solubility in common organic solvents (for example, maximum solubility in $\mathrm{CHCl}_{3}$ is $5 \mathrm{mg} / \mathrm{mL}$ ); therefore, ${ }^{13} \mathrm{C}$ NMR spectroscopy can not be measured.

(ii-44) Synthesis of CN-H (Method II).

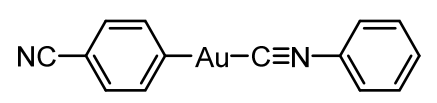

CN-H was prepared from 2-H $(675.5 \mathrm{mg}, 2.01 \mathrm{mmol})$ and organozinc iodide reagent (1-CN) in THF (3.26 ml, $3.00 \mathrm{mmol}, 0.92 \mathrm{M}$ ) according to Method II. Yield: 89\% (712.3 mg, $1.77 \mathrm{mmol}$, pale purple solid).

${ }^{1} \mathrm{H}$ NMR (392 MHz, $\left.\mathrm{CDCl}_{3}, \delta\right): 7.47-7.49(\mathrm{~m}, 2 \mathrm{H}), 7.50-7.55(\mathrm{~m}, 6 \mathrm{H}), 7.57-7.62(\mathrm{~m}, 1 \mathrm{H}) .{ }^{13} \mathrm{C} \mathrm{NMR}$ (99 MHz, $\mathrm{CDCl}_{3}, \delta$ ): $109.0(C), 120.0(C), 124.7$ (C), $126.7(C \mathrm{H}), 130.0(C), 131.5(C \mathrm{H}), 140.5$ $(\mathrm{CH}), 159.9(\mathrm{C}), 170.2(\mathrm{C})$. MS-FAB $(\mathrm{m} / \mathrm{z})$ : $[\mathrm{M}]^{+}$calcd for $\mathrm{C}_{14} \mathrm{H}_{9} \mathrm{~N}_{2} \mathrm{Au}, 402.0431$; found, 402.0431 . 
(ii-45) Synthesis of CN-Cl (Method II).

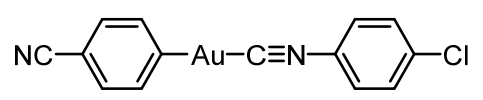

CN-Cl was prepared from 2-Cl $(186.5 \mathrm{mg}, 0.504 \mathrm{mmol})$ and organozinc iodide reagent (1-CN) in THF (0.815 ml, $0.750 \mathrm{mmol}, 0.92 \mathrm{M}$ ) according to Method II. Yield: 92\% (201.7 mg, $0.462 \mathrm{mmol}$, pale purple solid).

${ }^{1} \mathrm{H}$ NMR (392 MHz, $\left.\mathrm{CDCl}_{3}, \delta\right): 7.47-7.54(\mathrm{~m}, 8 \mathrm{H})$. MS-FAB $(\mathrm{m} / \mathrm{z})$ : $[\mathrm{M}]^{+}$calcd for $\mathrm{C}_{14} \mathrm{H}_{8} \mathrm{~N}_{2} \mathrm{ClAu}$, 436.0042; found, 436.0038. This compound exhibits poor solubility in common organic solvents (for example, maximum solubility in $\mathrm{CHCl}_{3}$ is $1 \mathrm{mg} / \mathrm{mL}$ ); therefore, ${ }^{13} \mathrm{C}$ NMR spectroscopy can not be measured.

(ii-46) Synthesis of $\mathbf{C N}-\mathbf{C F}_{3}$ (Method II).

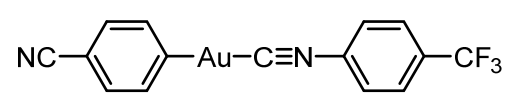

$\mathbf{C N}-\mathbf{C F}_{\mathbf{3}}$ was prepared from $\mathbf{2}-\mathbf{C F}_{\mathbf{3}}(809.3 \mathrm{mg}, 2.01 \mathrm{mmol})$ and organozinc iodide reagent (1-CN) in THF (3.06 ml, $3.00 \mathrm{mmol}, 0.98 \mathrm{M}$ ) according to Method II. Yield: 87\% (821.6 mg, $1.75 \mathrm{mmol}$, pale purple solid).

${ }^{1} \mathrm{H}$ NMR $\left(392 \mathrm{MHz}, \mathrm{CDCl}_{3}, \delta\right): 7.51$ (q, $\left.J=8.8 \mathrm{~Hz}, 4 \mathrm{H}\right), 7.70(\mathrm{~d}, J=7.8 \mathrm{~Hz}, 2 \mathrm{H}), 7.82(\mathrm{~d}, J=8.6 \mathrm{~Hz}$, 2H). ${ }^{13} \mathrm{C}$ NMR (99 MHz, $\mathrm{CDCl}_{3}, \delta$ ): $109.2(C), 119.9(C), 122.8$ (q, $\left.{ }^{1} J_{\mathrm{C}-\mathrm{F}}=274 \mathrm{~Hz}, C_{3}\right), 127.3(C \mathrm{H})$, $127.4\left(\mathrm{~d},{ }^{3} J_{\mathrm{C}-\mathrm{F}}=3.8 \mathrm{~Hz}, C \mathrm{H}\right), 127.6(C), 130.1(C \mathrm{H}), 133.4\left(\mathrm{q},{ }^{2} J_{\mathrm{C}-\mathrm{F}}=34 \mathrm{~Hz}, C\right), 140.5(C \mathrm{H}), 162.2$ (C), 169.7 (C). MS-FAB (m/z): [M] $]^{+}$calcd for $\mathrm{C}_{15} \mathrm{H}_{8} \mathrm{~N}_{2} \mathrm{~F}_{3} \mathrm{Au}, 470.0305$; found, 470.0312.

(ii-47) Synthesis of CN-CN (Method II).

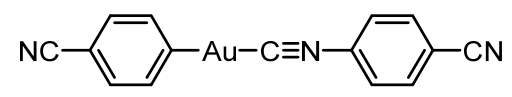

CN-CN was prepared from 2-CN $(181.3 \mathrm{mg}, 0.503 \mathrm{mmol})$ and organozinc iodide reagent $(\mathbf{1 - C N})$ in THF (0.815 ml, $0.750 \mathrm{mmol}, 0.92 \mathrm{M})$ according to Method II. Yield: 50\% (107.2 mg, $0.251 \mathrm{mmol}$, pale purple solid).

${ }^{1} \mathrm{H}$ NMR (392 MHz, $\left.\mathrm{CDCl}_{3}, \delta\right): 7.48-7.53$ (m, 4H), 7.70 (d, $\left.J=8.6 \mathrm{~Hz}, 2 \mathrm{H}\right), 7.86(\mathrm{~d}, J=8.2 \mathrm{~Hz}, 2 \mathrm{H})$. MS-ESI $(\mathrm{m} / \mathrm{z})$; $[\mathrm{M}+\mathrm{H}]^{+}$calcd for $\mathrm{C}_{15} \mathrm{H}_{9} \mathrm{~N}_{3} \mathrm{Au}, 428.0462$; found, 428.0462. This compound exhibits poor solubility in common organic solvents (for example, maximum solubility in $\mathrm{CHCl}_{3}$ is 0.2 $\mathrm{mg} / \mathrm{mL})$; therefore, ${ }^{13} \mathrm{C}$ NMR spectroscopy can not be measured.

(ii-48) Synthesis of $\mathbf{C N - N O}$ (Method II). 


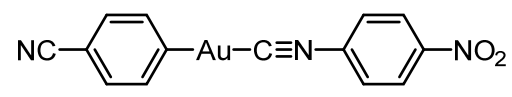

CN-NO 2 was prepared from $\mathbf{2}-\mathbf{N O}_{2}(191.8 \mathrm{mg}, 0.504 \mathrm{mmol})$ and organozinc iodide reagent (1-CN) in THF (0.815 ml, $0.750 \mathrm{mmol}, 0.92 \mathrm{M}$ ) according to Method II. Yield: 74\% (167.4 mg, $0.374 \mathrm{mmol}$, pale purple solid).

${ }^{1} \mathrm{H}$ NMR (392 MHz, $\left.\mathrm{CDCl}_{3}, \delta\right): 7.51$ (q, $\left.J=7.6 \mathrm{~Hz}, 4 \mathrm{H}\right), 7.75-7.79(\mathrm{~m}, 2 \mathrm{H}), 8.41-8.44(\mathrm{~m}, 2 \mathrm{H})$. MS-ESI $(m / z)$ : $[\mathrm{M}+\mathrm{H}]^{+}$calcd for $\mathrm{C}_{14} \mathrm{H}_{9} \mathrm{O}_{2} \mathrm{~N}_{3} \mathrm{Au}$, 448.0360; found, 448.0347. This compound exhibits poor solubility in common organic solvents (for example, maximum solubility in $\mathrm{CHCl}_{3}$ is 0.6 $\mathrm{mg} / \mathrm{mL})$; therefore, ${ }^{13} \mathrm{C}$ NMR spectroscopy can not be measured. 


\section{References}

S1. Sheldrick, G. M. Acta Crystallogr., Sect. A 2008, 64, 112.

S2. http://www.ccdc.cam.ac.uk/free_services/mercury/downloads/Mercury_3.0/

S3. Gaussian 09, Revision C.01, M. J. Frisch, G. W. Trucks, H. B. Schlegel, G. E. Scuseria, M. A. Robb, J. R. Cheeseman, G. Scalmani, V. Barone, B. Mennucci, G. A. Petersson, H. Nakatsuji, M. Caricato, X. Li, H. P. Hratchian, A. F. Izmaylov, J. Bloino, G. Zheng, J. L. Sonnenberg, M. Hada, M. Ehara, K. Toyota, R. Fukuda, J. Hasegawa, M. Ishida, T. Nakajima, Y. Honda, O. Kitao, H. Nakai, T. Vreven, J. A. Montgomery, Jr., J. E. Peralta, F. Ogliaro, M. Bearpark, J. J. Heyd, E. Brothers, K. N. Kudin, V. N. Staroverov, R. Kobayashi, J. Normand, K. Raghavachari, A. Rendell, J. C. Burant, S. S. Iyengar, J. Tomasi, M. Cossi, N. Rega, J. M. Millam, M. Klene, J. E. Knox, J. B. Cross, V. Bakken, C. Adamo, J. Jaramillo, R. Gomperts, R. E. Stratmann, O. Yazyev, A. J. Austin, R. Cammi, C. Pomelli, J. W. Ochterski, R. L. Martin, K. Morokuma, V. G. Zakrzewski, G. A. Voth, P. Salvador, J. J. Dannenberg, S. Dapprich, A. D. Daniels, Ö. Farkas, J. B. Foresman, J. V. Ortiz, J. Cioslowski, and D. J. Fox, Gaussian, Inc., Wallingford CT, 2009.

S4. (a) A. D. Becke, Phys. Rev. A 1988, 38, 3098-3100; (b) C. Lee, W. Yang, R. G. Parr, Phys. Rev. B 1988, 37, 785-789; (c) A. D. Becke, J. Chem. Phys. 1993, 98, 5648-5652; (d) T. H. Dunning, J. Chem. Phys. 1989, 90, 1007-1023.

S5. Spartan '10; Wavefunction, Inc.: Irvine, CA.

S6. Avogadro: http://sourceforge.net/projects/avogadro/

S7. H. Ito, M. Muromoto, S. Kurenuma, S. Ishizaka, N. Kitamura, H. Sato, T. Seki, Nat. Commun. 2013, 4, 2009.

S8. A. Krasovskiy, V. Malakhov, A. Gavryushin, P. Knochel, Angew. Chem. Int. Ed. 2006, 45, 60406044.

S9. A. S. K. Hashmi, T. Hengst, C. Lothschtz, F. Rominger Adv. Synth. Catal. 2010, 352, 1315-1337. S10. (a) F. Bonati, G. Minghetti, Gazz. Chim. Ital. 1973, 373-386; (b) C. Bartolomé, Z. Ramiro, D. García-Cuadrado, P. Pérez-Galán, M. Raducan, C. Bour, A. M. Echavarren, Pablo Espinet, Organometallics 2010, 29, 951-956.

S11. D. Riedel, T. Wurm, K. Graf, M. Rudolph, F. Rominger, A. S. K. Hashmi Adv. Synth. Catal. 2015, 357, 1515-1523. 